\title{
FSPubs
}

ND

1839

.T47

A4

1996

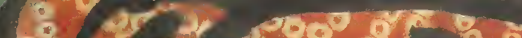

2.

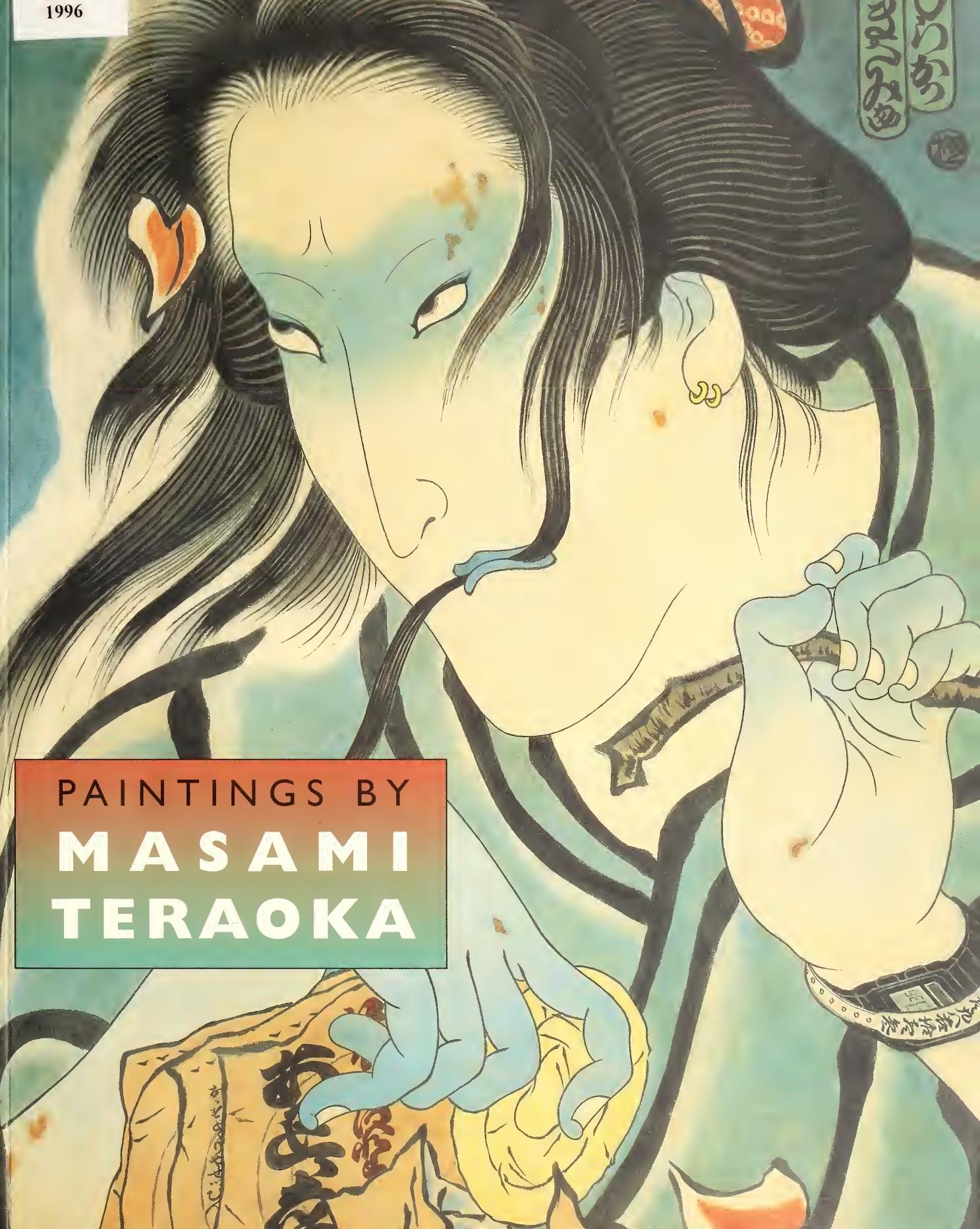




\section{PAINTINGS BY MASAMI TERAOKA}

James T. Ulak, Alexandra Munroe, and

Masami Teraoka with Lynda Hess

Japanese-born artist Masami Teraoka, now a resident of Hawaii, brings penetrating insight and astonishing technical skill to the search for love and identity in a world created on the fault line between two cultures. Brilliantly exploiting the imagery of pop art in combination with traditional Japanese ukiyo-e woodblock prints, Teraoka explores in his paintings how the contemporary dilemma over gender, identity, and sexual behavior influences people's lives and experiences.

Ukiyo, or "the floating world," in Edo-period Japan (1615-1868) evoked the transitory world of Kabuki theater and pleasure houses. The term also applied to the genre images that recorded that life, particularly in woodblock prints (ukiyo-e). Popular subjects included portraits of actors and courtesans, Kabuki theater, landscape views, and erotica. Teraoka taps the graphic power and elegant color of these works, including the use of seals, calligraphy, and ornately framed cartouches, and revels in covert meanings, combining verbal and visual puns with alluring color and pattern.

Astonishingly, he uses watercolor to create the appearance of the woodblock print, but with signature late twentiethcentury twists and turns.

Integrating traditional ukiyo-e imagery and subject matter with pop art, the artist casts contemporary issues related to AIDS, computer mouses, environmental degradation, and drive-by shootings, in historical guise. His unabashed use of humor and satire combines with a vibrant personal iconography drawn from Japanese and Western sources - catfish, trickster fox, ghost, snake, ninja, samurai, geisha, Adam, Eve, punk rockers, television, and London buses. Teraoka's recent work moves from the indulgent pleasures of the floating world to a chastened consciousness of death and evil with a majestic virtuosity unique in contemporary art. 



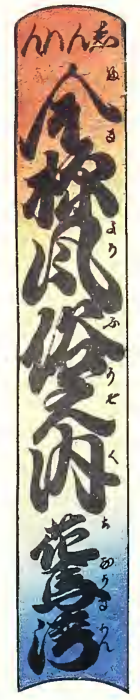




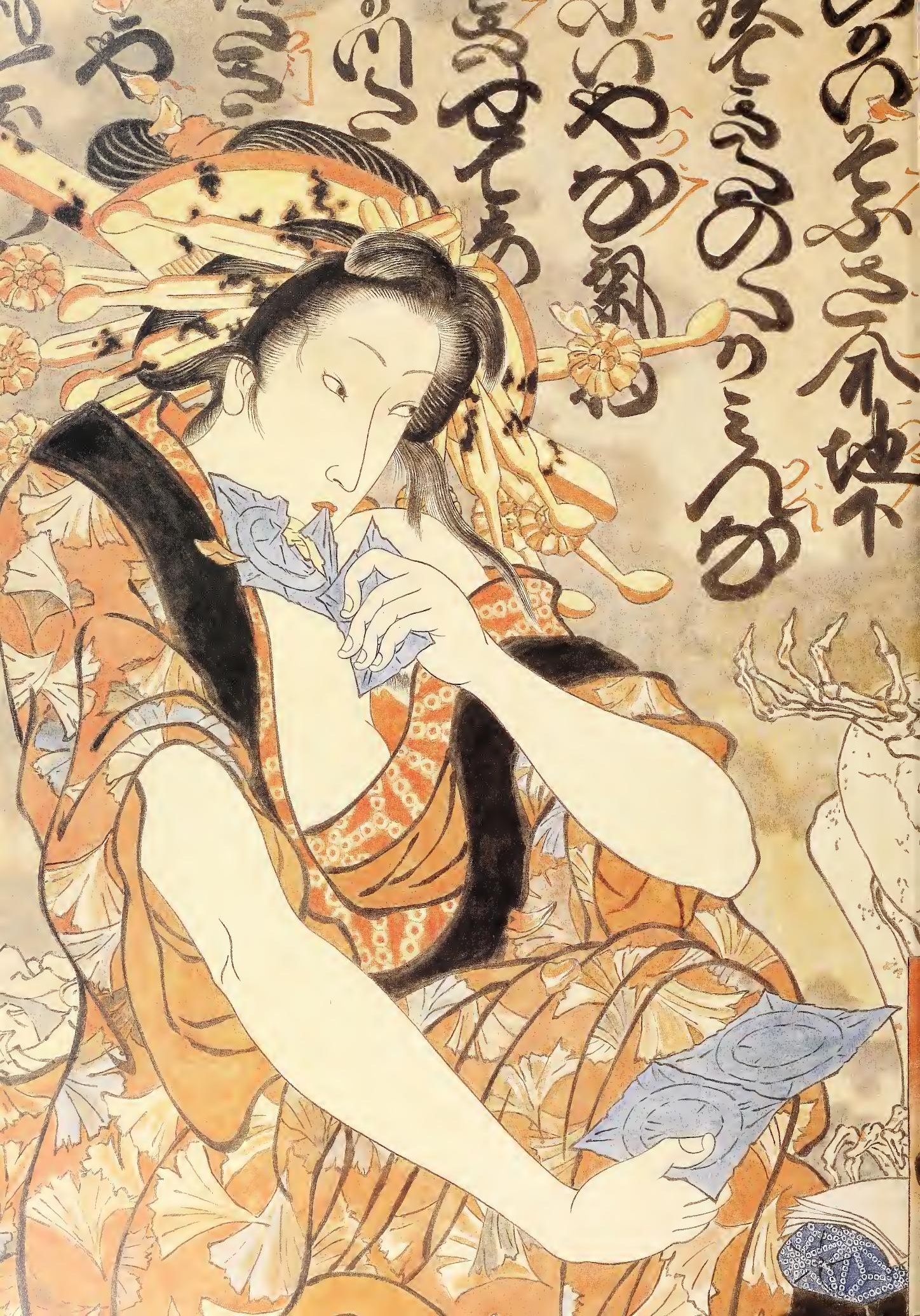




\section{PAINTINGS BY MASAMI TERAOKA}

James T. Ulak $\lrcorner$ Alexandra Munroe $\lrcorner$ Masami Teraoka with Lynda Hess

Arthur M. Sackler Gallery, Smithsonian Institution, Washington, D.C., in association with Weatherhill, Inc., New York and Tokyo 
Copyright (C) 1996 Smithsonian Institution.

All rights reserved.

Published by the Arthur M. Sackler Gallery,

Smithsonian Institution, Washington, D.C., in association with Weatherhill, Inc., New York and Tokyo.

Published on the occasion of an exhibition at the Arthur M. Sackler Gallery, June 30-December I, 1996. The exhibition is made possible by a generous grant from Peggy and Richard Danziger.

Additional funding is provided by the

Smithsonian Institution Special Exhibition Fund.

Front cover: Masami Teraoka, AIDS Series / Geisha and AIDS Nightmare (detail), 1990.Watercolor on unstretched canvas. See no. 3.

Half title: Masami Teraoka, Hawaii Snorkel Series/Longing Samurai (detail), 1993. Woodcut, etching, and aquatint on paper. See no. 25

Frontispiece: Masami Teraoka, Tale of a Thousand Condoms/Geisha and Skeleton (detail), 1989. Watercolor and sumi-e ink on unstretched canvas. See no. 28.

Library of Congress Cataloging-in-Publication Data Teraoka, Masami, 1936

Paintings by Masami Teraoka/James T. Ulak ... [et al.]

p. $\mathrm{cm}$.

Includes bibliographical references and index. ISBN 0-8348-0352-6 (alk, paper)

1. Teraoka, Masami. 1936- - Themes, motives.

2. Ukiyo-e — Influence. I. Ulak, James T. II.Title.

ND 1839.T47A4 1996

96-7137

$759.13-$ dc 20
The paper used in this publication meets the minimum requirements for the American National Standard for Permanence of Paper for Printed Library Materials, Z39.48-1984

Edited by Karen Sagstetter

Designed by Carol Beehler

Composed in Gill Sans on Apple Macintosh

Printed by Oceanic Graphic Printing, Hong Kong

Credits

Works by Masami Teraoka @ Masami Teraoka except pp. 86-88: (C) copyright 1993 Masami Teraoka/Tyler Graphics Ltd. Photographs: courtesy Masami Teraoka, pp. 12, 13, 15, 19, 20-21, 34, 42; Copyright British Museum, pp. 23, 26; ( Roy Lichtenstein/courtesy Leo Castelli Gallery, New York, p. 37; Hyogo Prefectural Museum of Modern Art, Kobe, p. 38; (C) Tadanori Yokoo, p. 41; courtesy of the artist and the Patricia Faure Gallery, Santa Monica, Calif., p. 45; Kawaguchi Museum of Contemporary Art, Saitama Prefecture, Japan, p. 46; courtesy of the artist and Metro Pictures, New York, p. 47; photo by Lynda Hess, p. 60. Portfolio; all photos courtesy Pamela Auchincloss Gallery, New York, except pp. 62, 69, 77, 94,97-99, 101-104: courtesy Masami Teraoka. 


\section{CONTENTS}

6 Foreword a Milo Cleveland Beach

8 Acknowledgments

II Catfish in Love $\square$ JamesT. Ulak

33 Pulp Fiction and the Floating World a Alexandra Munroe

50 Monitoring OurTimes a MasamiTeraoka with Lynda Hess

56 Biography

61 Portfolio

106 Annotated Bibliography

110 Index 


\section{MILO CLEVELAND BEACH}

Director, Arthur M. Sackler Gallery and Freer Gallery of Art

$N$ RETROSPECT, it seems almost inevitable that the paths of the Arthur M. Sackler Gallery and Masami Teraoka would intersect. Since opening to the public in 1987, the Sackler has attempted to reexamine and extend generally held notions of what constitutes Asian art; this includes not only the major art-historical traditions, but also those realms not usually linked in the popular Western imagination to Asia, such as contemporary art. Masami Teraoka, a Japanese-born contemporary painter now living in Hawaii, also looks over his shoulder to the past, but not with the eyes of an art historian. He uses history for his own reasons - to paint the present and future.

Paintings by Masami Teraoka documents the artist's construction of worlds. They are places that resonate, oftentimes brightly but now with increasing darkness, through structures and spaces somehow dislocated and adrift. Mining the visual strategies and conventions of disparate times and locations - Japanese woodblock prints, pop art, and, recently, the art of late Gothic and Renaissance Europe - Teraoka creates an elaborately choreographed, cross-cultural universe that skewers common assumptions and subverts mythologies. Yet his appropriations are neither random nor superficial; his transferral of an ukiyo-e ethos and vocabulary to contemporary issues, for example, is grounded in a deep knowledge and understanding of historical masters such as Katsushika Hokusai (1759-1849) and Utagawa Kunisada (1786-1865).

Beginning in the 1970s, Teraoka has methodically assembled a wildly rich, culturally encoded landscape populated by archetypes both from the past and of his own making. Originally regarded as a clever satirist who brought a sophisticated "decorative" talent and his own "exotic" Japanese sensibility to the Western artistic arena, Teraoka developed as a far more 
challenging visual thinker. His paintings reflect an inherent impulse to represent imaginatively, to narrate, the concerns and dilemmas of the later twentieth century: identity, cultural diversity, human sexuality, AIDS, technology, and environmental pillage. He has joined this discourse by using the past as both foil and vehicle for his own uneasy musings; aided by sly humor, eroticism, and a stunning graphic sense, he disarms the viewer and recasts in fittingly paradoxical and contradictory terms the raucous welter of cultural, social, political, and economic formations battling for dominance in the present day. Historical specificity - whether anchored in nineteenth-century Edo, California in the sixties and seventies, or fifteenth-century Europe - is in one sense merely a visual stalking-horse, a decoy, for Teraoka's own critical inquiry.

This publication is the result of a collective effort on the part of three authors. James T. Ulak, associate curator of Japanese art, Arthur M. Sackler Gallery and Freer Gallery of Art, brings to the work of Masami Teraoka not only a broad knowledge of historical Japanese artistic practice and theory, but also a deep empathy for the cultural origins and motivations that have shaped the artist; this informed placement of Teraoka in the long continuum of Japanese visual thought is a welcome contribution. Alexandra Munroe, whose 1994 Japanese Art after 1945: Scream Against the Sky exhibition and book reconfigured Western perceptions of Japanese artistic contributions in the postwar period, has positioned Teraoka's paintings firmly within the mainstream of contemporary aesthetic concerns, not on the margins. Masami Teraoka's own essay reveals in characteristically gentle and reflective tones the unease and growing peril created by the world he surveys and paints. The book that presents these three essays — indeed, the entire project-was guided for the Sackler Gallery by its deputy director, Thomas W. Lentz. He has been significantly involved with both the choice of images to be shown and the articulation of critical issues. We are tremendously indebted to Peggy and Richard Danziger, deeply informed connoisseurs of Japanese art and early collectors of Teraoka's work, for their enthusiastic support-intellectual as well as financial. The Smithsonian Institution Special Exhibition Fund also provided funding.

These paintings point to a continually evolving interest in appropriation as a means of illumination. What Teraoka's distinctive artistic tropes and historical conceits ultimately achieve is a blurring of the dichotomy between the individual and the universal, and we as viewers, in empathy and fascination, are drawn in. 
OMMITMENT to providing a venue for important contemporary artists whose works reflect an Asian perspective led the Arthur M. Sackler Gallery to Masami Teraoka. Paintings by Masami Teraoka was initiated by Milo C. Beach, director of the Arthur M. Sackler Gallery and the Freer Gallery of Art, andThomas W. Lentz, deputy director.They have been thoroughly conversant with the myriad details of the book and exhibition that constitute this project and generously supportive at every stage.

Masami Teraoka has been a source of unfailing wit and cooperation. He has extended the privileged invitation of dialogue concerning works in progress. He has been particularly goodnatured in responding to the views of his self-appointed interpreters. Lynda Hess, an independent writer and contributor to many Teraoka projects, has offered insight and clarification in all aspects of the preparation of the exhibition and book.

The advice and thoughts of Roger S. Keyes, director of the Center for the Study of Japanese Prints, are sprinkled throughout the publication and exhibition. The prints and drawings by Utagawa Kunisada presented as supportive material in this exhibition are borrowed from Masami Teraoka's personal collection in consultation with Dr. Keyes.

Pamela Auchincloss, Jeremy Adams, and the staff of the Pamela Auchincloss Gallery, New York, were of considerable assistance at all levels of organization and we are grateful for their cooperation.

This publication was produced under the deft editorial direction of Karen Sagstetter, editor in chief, Arthur M. Sackler Gallery and Freer Gallery of Art. Working under the pressure of unusual constraints, she retained an impressive command of nuance and detail. Carol Beehler's 
provocative book design brings us closer to the fierce beauty of Teraoka's art. We are grateful for editor Susannah Gardiner's expertise and good taste and for Mary Cleary's editorial skill. We particularly appreciate our colleagues at Weatherhill for their commitment to quality.

Vickie Reese, administrative assistant to the deputy director, was a tireless coordinator of logistical matters, as was Sarah Wilke, curatorial assistant, who also took thoughtful care in preparing the manuscript for this book. Thanks go to Patrick Sears, associate director; Richard Franklin, head of design; Nancy Hacskaylo, graphic designer; and all the accomplished Sackler Gallery staff whose talents brought the exhibition into being.

J.T.U. 


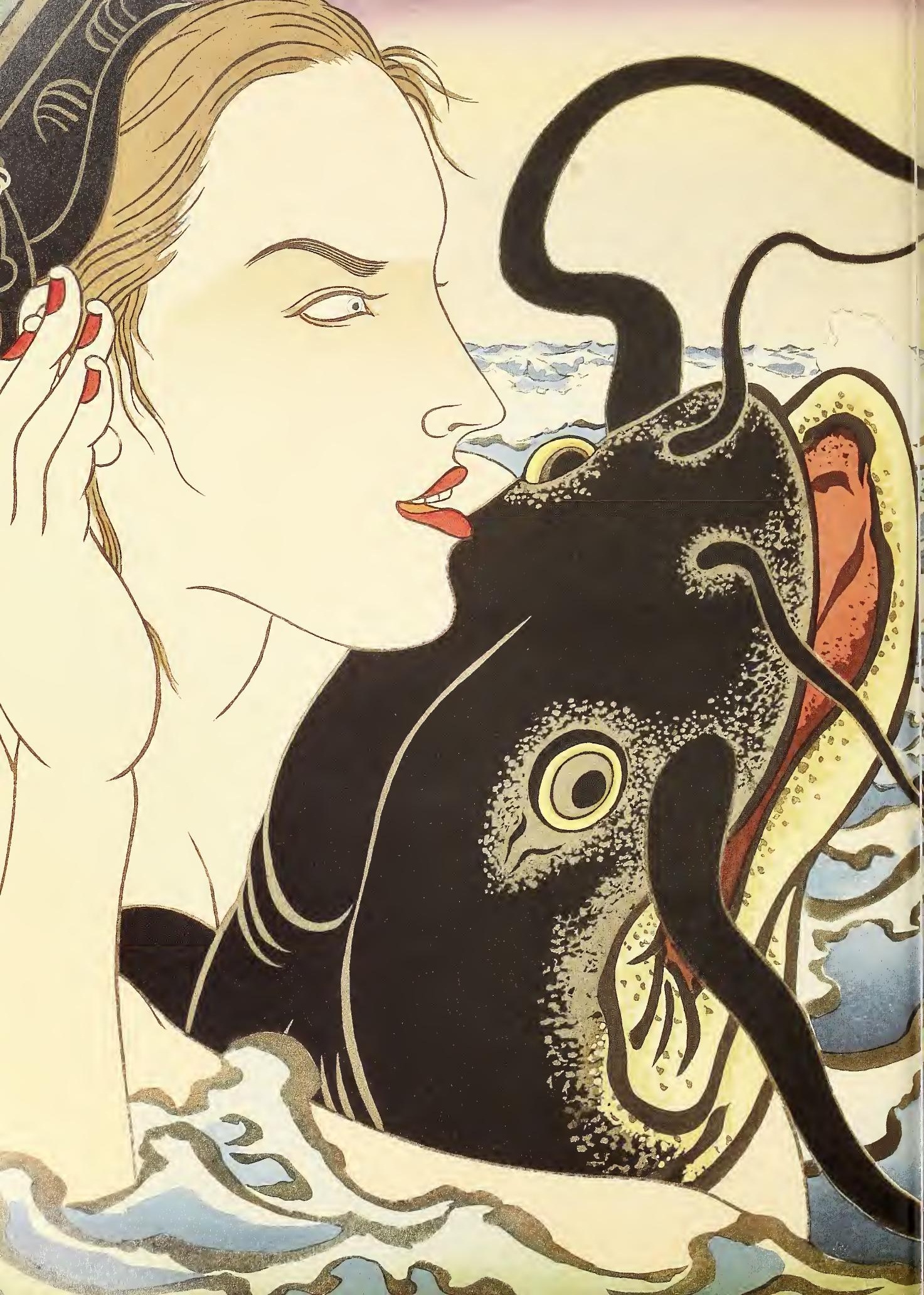




\section{JAMES T. ULAK}

HE MASAMI TERAOKA Ur-painting, VeniceNude Beach/

Self-Portrait, 1975, is a self-portrait of the artist as a displaced person, a nineteenth-century Japanese pilgrim transported to the lotion-slick sands of Venice Beach, California (see fig. I).

Venice Nude Beach/Self-Portrait is a narrative painting in two parts. In the first painting, a kimono-clad, hirsute, and bespectacled gentleman sits with his back to the vast Pacific. Arms crossed determinedly, he glares at his reflection in the oval of an old-fashioned, wood and lacquer mounted mirror. The pose is borrowed and adapted from a print image by Utagawa Kunisada (1786-1865) done in the 1840s. It is the image of a famous actor's bombast and bravura. Under Teraoka's good-humored tutelage, the pose is transformed into a study of concentrated reflection tweaked by distraction. Far to the man's rear, two nude women lounge at the ocean's edge. The angle of the mirror must surely bring them into view. The reflected view might also offer a moment to pause and look back over the distance of the journey already undertaken.

In the second painting in the sequence, known as Venice Nude Beach/Bicycle and Woman, 1975, the over-the-shoulder distraction becomes more powerfully obvious. Heading home from the beach, the artist-in-self-portrait bends to unlock a chain from the rear wheel of his bike. He turns to see a bikini bra in midair, tossed over the shoulder by a beauty seen in stop-action strip. Balanced on one foot, she eases off the bikini bottom with a tug of her ankle. She touches herself. She is free, dramatically unencumbered, and blatantly inviting. He is startled, bumbling, weirdly costumed. Her fluid, fleshy pirouette contrasts with his bowlegged, covered-body stoop. His hand struggles

Masami Teraoka, Hawaii Snorkel Series/Catfish Envy (detail), 1993. See no. 26. through spokes and chains to unlock his means of mobility.

Imagine the overlaid, semitransparent sheets in an anatomy textbook. With the turning of successive pages, you descend into the 


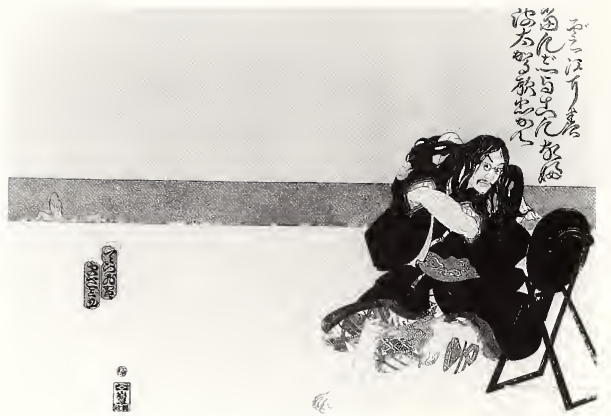

Figure I left, Masami Teraoka, Venice Nude Beach/Self-Portrait, 1975. Watercolor on paper, $36.8 \times 54.6$. Collection of Esther and Donald Richmond, Santa Monica; right, Venice Nude Beach/Bicycle and Woman, 1975. Watercolor on paper, $36.8 \times 54.6$. Collection of Debbie Doolittle, Los Angeles.

body, from epidermis to skeletal structure. Or reverse the process. Or flip back and forth and in between. The semitransparent sheets of the Venice Nude Beach paintings contain the varied conventions of the premodern Japanese woodblock print image. Seal marks of every sort identify artist, publisher, and censor; other Japanese text offers commentary and title. Then there is the posture and comportment of the protagonist. All of the apparatus necessary for representing a foreign and fantastic worldview is superimposed on a scene from Venice Beach. Visual time travel and outrageous juxtaposition: imagine the possibilities.

This work, perhaps more than any other of Masami Teraoka's early paintings, contains the seeds of themes and methods that have occupied him for twenty years. With admirable economy of rendered forms, Teraoka offers to us a moment of comic sexual tension, gives a conspiratorial wink, and begins at Venice Beach what will be a lengthy and intriguing discourse on the consequences and rewards of freedom and desire. His is the story of the samurai in La-La Land, and it is autobiographical. But the story is about all of us. The dominant metaphor is sexuality. How do we relate our total body/self to other total body/selves? Are we one and the same with the "natural" world around us? Or is there something that sets us apart? Is "nature" benevolent or will it betray us? Are we in the world or of the world? Are we, like the artist-in-self-portrait, stunned with desire yet somehow fettered in the face of ravishingly natural invitation?

Teraoka's story can be read in broadly discernible stages. First, there is a movement of playful, satirical, raunchy observations on the tragicomic encounters between Japan and the West. Greed and environmental destruction are among the prominent subjects. Then there is a series of parallel epiphanies in which satire matures to righteous rage in face of the AIDS (acquired immunodeficiency syndrome) epidemic, and polymorphous lust mellows into a charming love story. More recent work suggests a sober assessment of love, of the self, and of the other.We seem to survive in a dark and threatening world where even the best of relations are prophylacticized. Technology becomes our intermediary in human contact, our substitute for touching. There 


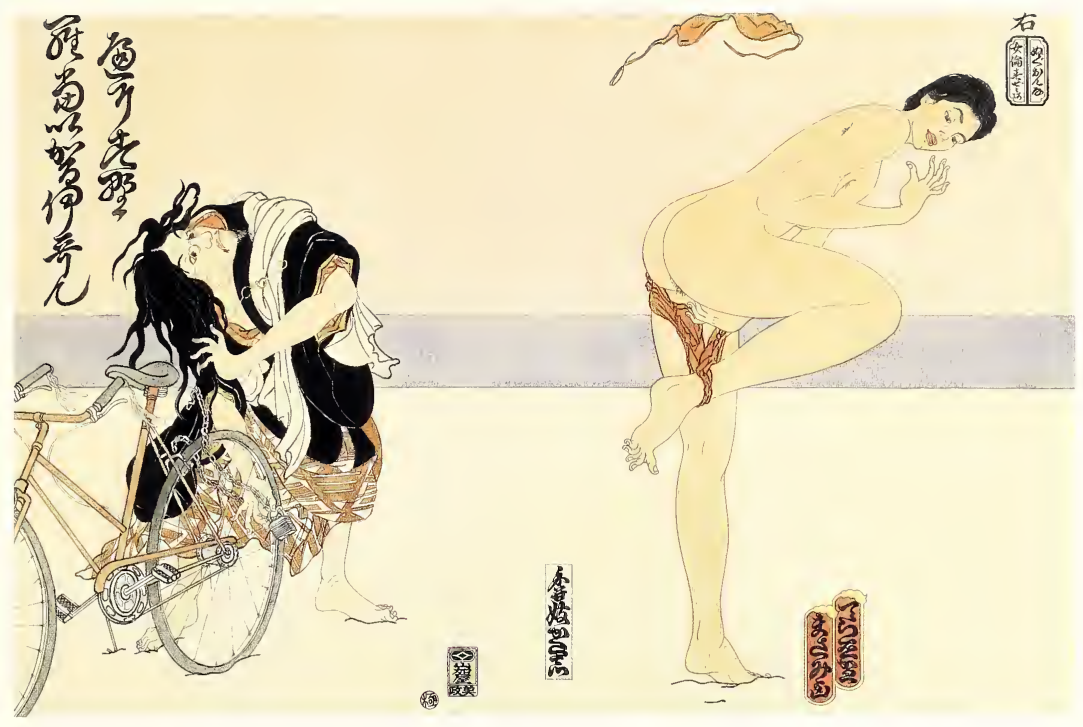

is a perception of looming threat in many of his works. Sometimes it is objectified, as in the scourge of AIDS. At other times it is an inarticulate and dark suggestion. In the later works Teraoka begins to hint that the threat may not now come from the medical facts of disease but from the very nature of who we are: beings attracted to and courted by death in a pilgrimage toward light. What are the sources of our undoing and of our renewal?

Teraoka has the method of a playful optometrist. He drops and lifts an array of lenses before our eyes. Some sharpen, others blur, in a fan dance of shifting perceptions about reality. The lenses he flips are archaic, foreign, and sometimes futuristic visions, prisms through which to observe what we think is the present reality. The most consistently effective has been his use of the conventions of the nineteenth-century Japanese woodblock print. Recently, Teraoka has also opened a conversation with the tradition of European iconography. The imagery of a number of late Gothic and Renaissance painters, including Hieronymus Bosch (ca. 1450-1516), Hans Baldung-Grien (ca. 1484-1545), and Antonello da Messina (ca. 1430-1479), inform Teraoka's thematic developments. These and other European artists were, in myriad ways, depicting visually the fault line of a vast cultural shift. The shift involved Teraoka's implicit conundrum: Are we in the world or of it? And how do we relate to the flesh, the world's most significant manifestation? Teraoka spots a key moment in the ongoing Western discussion of the body and deftly relates it to his own narrative. Standing at the advent of the Renaissance, the Catholic Bosch's anonymous steadfast pilgrim trudges through the world's temptations, and his Saint Anthony is beset by every 
imaginable seductive voice. Yet the artist's pedagogic purpose is almost overwhelmed by his own fascination with the outrageously multifaceted depictions of the flesh in action. And the Protestant Baldung-Grien renders Adam and Eve with all the sensuality of pagan gods on the verge of frolic, thus interpreting the Fall with a decidedly sexual cast. As the Renaissance, particularly as manifested in Italy, takes hold, the loving attention given to renderings of the human form suggests, when applied to the images of Jesus and the Resurrected Christ, a flesh real yet glorified. Teraoka instinctively grasps that destinations on his pilgrimage must include what seem to be opposite interpretations: a Buddhist distrust of the flesh and a moment in Christendom when the implications of incarnation transcended guilt. His strategy serves up a pastiche of myths, symbols, culturally circumscribed ways of seeing, ways of rendering what is seen, and fragments of historically grounded concern and controversy. Calculation, whimsy, and the unpredictable forces unleashed by felicitous juxtaposition are applied in a generous mix.

Man and woman. Woman and beast. Ghoul and gal. The combinations seem endless. How do we represent in an image the psychological stratifications, the cosmic implications of a single coupling? Teraoka poses the question at Venice Beach. It is critical to his program that the viewer, in concert with the searching artist, grow in an awareness of the necessity for exploring the issues. Sexuality is two-faced - life-giving and death-dealing. It is an essential contradiction understood, and perhaps resolved, not through rational discourse but in the language of fantasy, myth, and dream. And to that end, Teraoka commandeers the visual vocabulary of the cultures of nineteenth-century Japan and medieval Europe. His choice of arenas is astute, and probably intuitive. These are, of course, vast and very different realms.

\section{Teraoka and the Demimonde}

Teraoka professes a profound indebtedness to the Japanese artist Utagawa Kunisada (1786-1865). And this is important to remember.Teraoka is not an illustrator parodying an archaic style for a few quick and clever laughs. Working from his personal collection of the master's prints and drawings, he has obviously immersed himself in the subtleties of mood, theme, composition, and brushwork. 
Utagawa Kunisada (1786-1865) was born in Edo (now Tokyo) into a prosperous family with cultural aspirations. His father operated a ferry service and was an amateur poet of some note, participating in poetry clubs whose membership included famous actors and literary personages of the day. It was through these associations that the young Kunisada developed his lifelong attraction to the theater world and to literature. These contacts provided a fruitful matrix of stimulation and patronage that greatly assisted Kunisada's career.

Kunisada's artistic talents were apparently precocious. Utagawa Toyokuni (1769-1825) accepted him as an apprentice at the age of fifteen. By his early twenties he was already launched as a successful book illustrator. As a print designer, Kunisada was a consummate professional. Organizationally adept, with numerous students and assistants in his studio, he is reputed to have produced at least twenty thousand distinct print designs in his career. His commercial output established his mastery first in theater prints, then in depictions of beauties; finally the illustration of a popularized rendition of The Tale of Genji brought him absolute national acclaim. His privately commissioned works included erotica, as well as commemorative and celebratory prints for poetry clubs and the fan clubs of famous actors. He may have been the most popular print designer of his day, although his reputation was eclipsed in the twentieth century by figures such as Ando Hiroshige (1797-1858) and Katsushika Hokusai (1759-1849). Western connoisseurs have often found his work coarse and garish.

Kunisada's depictions of women have an earthy, robust quality and a frank eroticism, somewhat different from the ethereal or idealized beauties of Kitagawa Utamaro (1753-1806) or Torii Kiyonaga (1752-1815). Theatricality, energetic figural rendering, and attention to minute detail (particularly in fashion) are characteristic of his work. His imaginative depictions of clothing and coiffures are known to have occasionally influenced fashion styles. Some of his best works are compositionally dense presentations that engage the viewer in a complex experience of image and word.

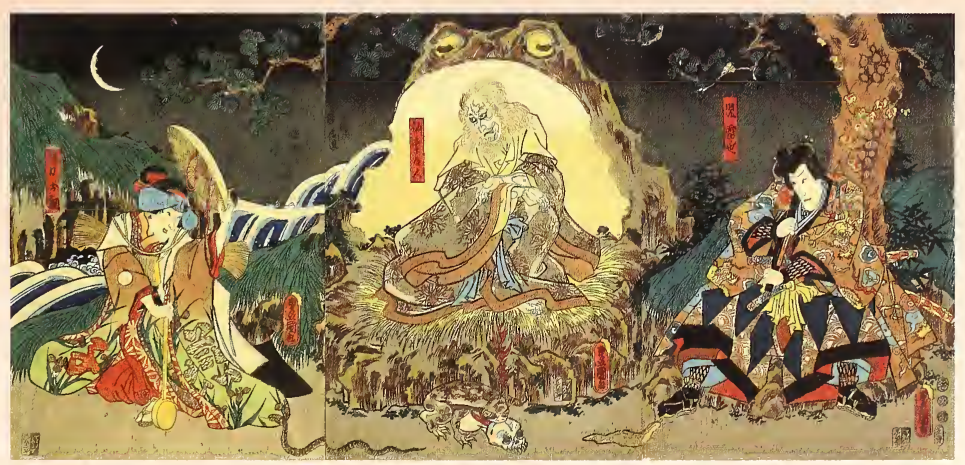

Utagawa Kunisada; print triptych depicting main characters from the Kabuki play jiraiya (left to right, Kairiki Otsuna, Sensodojin, Jiraiya), ca. I840s. Oban size: $36.9 \times 24.9$ each. Collection of Masami Teraoka. 
The distinctive modulations of Kunisada's brush have been absorbed by study and repetition into the rhythms that Teraoka now riffs and blends into his own work.

Much more than the vision of a single artist has been appropriated. Kunisada represents the delicious fruition of a perspective nurtured and developed in Japan for several hundred years. His art, his trade, was to effectively give image to the worlds of fantasy and desire-Kabuki theater and the brothel. This was the "floating world"- - ukiyo - and his pictures were ukiyo-e.

It is in this demimonde that Japanese artists indulged in their most uninhibited exploration of fantasy and sexuality - the creation of dreamscapes that included, indeed allowed for, the unencumbered introduction of the mythological and surreal. By Kunisada's time this was a satiated environment, a debauched and jaded world relentlessly haunted by and reminded of its origins in the Buddhist teachings of the transitory nature of existence.

The relative tranquillity of the Edo period (1615-1868) was bracketed by violence. The cessation of violence, and the emergence of a unified government, in the early seventeenth century had birthed the complex urban populations that avidly patronized the pleasure quarters. In the 1850s, when Kunisada was in his late sixties and early seventies, American, Russian, Dutch, British, and French ships hovered off the coast of the archipelago and pressed for trade concessions with a government that had been in selective seclusion for more than two hundred years. Shogunal authority was in a dizzying spiral of decline, and, in the vacuum, contending domestic political forces would enter into bloody civil war in the 1860s. That social disarray caused the jittery seismograph needle of pleasure-world art to register unease and give prescient indications of the violence yet to come. On stage and in prints, the public seemed increasingly gratified by themes that were macabre, intricately cruel, and sadomasochistic. As if in lieu of the possibility of real bloodshed, a national appetite whetted by frustration, fear, and confusion was still fed by fantasy.

From the seventeenth century, ukiyo had come to mean the world of frivolous, foppish, stylish, ephemeral pleasure-seeking. It was a world sanctioned, condoned, licensed, and then carefully monitored by the state. A long period of armed conflict had ended in the early seventeenth century, and a state constructed on a hierarchical neo-Confucian model was imposed as the social order. Pleasure was to be pursued only after duty was fulfilled. But it did have its place. The state maintained a view that sex and fantasy were indeterminate but powerful energies that could and 
should be safely channeled and dissipated for the efficient ordering of society. (The mollified citizen was distracted and malleable.) This was essentially a mechanistic approach. Government monitoring of this world of pleasure involved occasional periods of intense censorship and didactic tinkering, the latter occurring mainly through the encouragement of impresarios and artists to create high-minded themes to influence their captive audiences. But ironically, the "floating world" was an area in which a vast and perhaps initially unanticipated introspective exercise was conducted. The operative metaphor of sexuality was obviously strong, but through it the range of human emotion was gradually explored. Ukiyo-e portrayed the worlds of the "exposed" professions: actor and prostitute - those whom people paid to see. And within the genre of ukiyo-e they were seen, of course, in the costume and makeup of their respective roles, whether on stage or under coverlets. Then, gradually, they were deemed the ideal subjects to be viewed "out of role" in the dressing room or at their toilette. A great actor confers with a theater manager or practices a pose; a woman who professionally feigns passion and affection is observed in private tears. The artist was the recorder of a patron's fond memories, inevitably idealized; he was the creative fantasizer and the assigned voyeur of myriad physical and emotional states.

There were, of course, other subjects. Complete Kabuki scenes or tableaux were popular, as well as historical, mythological, and legendary subjects. These were found in painting, but far more frequently in the single-sheet woodblock print form and in books. Especially beginning in the late eighteenth century, there was an increasing interest in portraying landscape, stimulated in part by government censorship of brothel and theater subjects. But the artists who produced these were virtually all products of classical ukiyo-e training. Thus, style and manner carried over, and the most innocent of subjects were still injected with, if only by association, sensuality and theatricality.

Yet ukiyo has a complex etymological history. It described the Buddhist notion of transience and impermanence. Ukiyo, the floating world, the ever-changing world before our eyes: Attach to it and it will break your heart. All desire leads to pain, deception, and betrayal because its goal will ever be elusive. Reality is the word of a charlatan. Ukiyo is a powerful and pervasive religious perception that was translated into an equally important notion in Japanese aesthetics: the visual or literary expression of that moment when the fundamental fact of evanescence is perceived. This conjures the mood of a resigned or disengaged melancholy. It is a notion at the 
core of complex plots of literature and theater, from Murasaki Shikibu's tenth-century The Tale of Genji to Akira Kurosawa's 1950 film Rashomon.

The cheeky embrace of transience and its transformation from spiritual quest into fashion, which so characterized the pleasure worlds of Edo-period society, was an unwitting rapprochement with powerful forces that many thought had been exorcised by peace and prosperity. The pleasure worlds' celebration of ephemerality, ignoring pathways to deeper meaning, was just whistling in the dark. It only forestalled the inevitable introspection. Transience and ephemerality were too infused with complex meaning and power to be toyed with. A coiled viper. A dozing crocodile.

Ukiyo, the floating world, is the mantle Teraoka assumes, the semitransparent sheet he flips over our "reality." This complex matrix carries for the viewer implicit and explicit meanings. Those newly initiated into the world of Teraoka, often through secondary sources, are startled, on viewing his works, to learn that they are paintings, not prints. We are alerted to the fact that in his paintings we can anticipate every ploy, every nuance, every theme it is possible to discover in a print. Beyond exotica, we can expect to find frank and flamboyant sexual expression, cleverly encoded political commentary, disguised topicality, and immediacy. The ukiyo-e print represented risky business. It was the on-the-edge, the sometimes outlaw commentator. Although engendered by an escapist ethos, the ukiyo-e genre could never totally jettison the religious insights at the heart of ukiyo. And many works circle back in quirky ways to entertain more profound questions. Teraoka offers us the same promise.

\section{Catfish in Love and the Fisher of Night Waters}

Venice Nude Beach/Self-Portrait posits that Teraoka, Everyman, is a pilgrim in the land of desire. In the same year in which he created that image, he produced two others that opened routes to a more complex nuancing of his identity. Through each of these paintings, he extended his range of assumed identities, though the Teraoka face encountered in Venice Nude Beach is still recognizable. He found ways that gradually allowed him to expand his searcher/observer definition of self. In 
New Views of Mt. Fuji La BreaTar Pits and Zen Garden, 1975 (fig. 2), the artist renders himself as a Buddhist priest sweeping leaves outside a temple wall, placed as an observer of the chaos caused by greed and of an environment befouled. The other painting, Santa Monica Pier, 1975 (fig. 3), shows Teraoka as a fisherman/warrior straddling for balance in a boat on which a small fire burns at the prow. Traditionally a flame like this was used to draw fish to the surface. They were netted, hooked, snared, and, most remarkably, retrieved by trained cormorants. A metal ring on the large black bird's neck prevented it from swallowing, the obvious temptation. And a line to the fisherman's hand guided the cormorant home. In this painting Teraoka has hooked a bottle. A reference to pollution, perhaps. But night fishing is an ancient Japanese sexual metaphor: the line, the pole, or, more common in love poetry, the long-necked cormorant dipping into dark waters. Teraoka's representation of himself with a Buddhist monk's costume and posture suggests one engaged in a profound search pausing in bemused observation of folly. The fisherman/samurai presents a visually more active type aggressively seeking sustenance from the opaque depths. But neither is merely an observer. Teraoka's postures of search and advantageous viewing would later dress him in the costume of geisha, with wispy moustache (3/ Flavors Invading Japan/Rocky Road, 1977), and as a black-clad ninja voyeur (London Tube Series/Camden Eve,

Figure 2 Masami Teraoka, New Views of Mt. Fuij/La Brea Tar Pits and Zen Garden. 1975. Watercolor on paper, $27.9 \times 139.7$. Minneapolis Institute of Arts, Minneapolis, Minnesota; funds from Mrs. Patrick Butler and miscellaneous purchase funds.
1993; no. 30).Through these various roles the viewer gradually understands that the narrative forming the artist's work is not a linear movement describing the journey of a pilgrim through a minefield of temptation toward a goal of marvelous spiritual clarity. Teraoka chooses the highly nuanced language of visualized myth and startling role to tell his story. In doing so, he

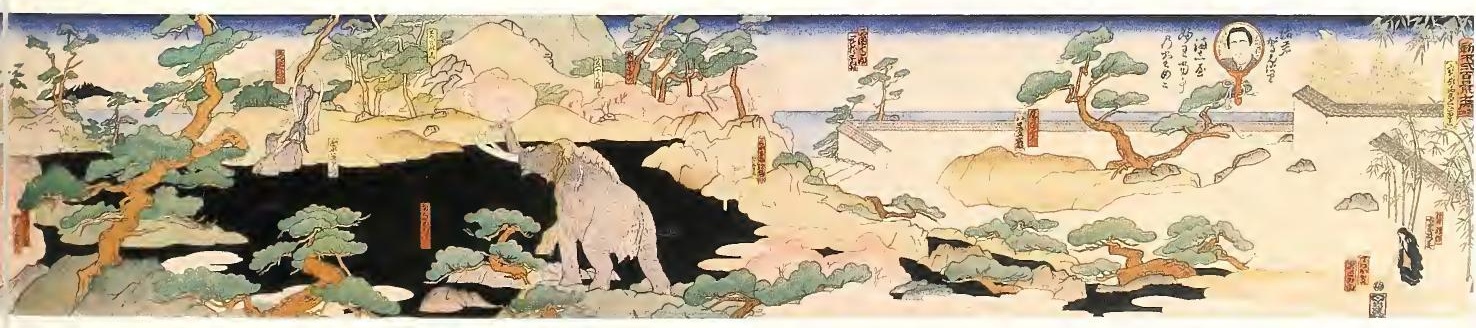




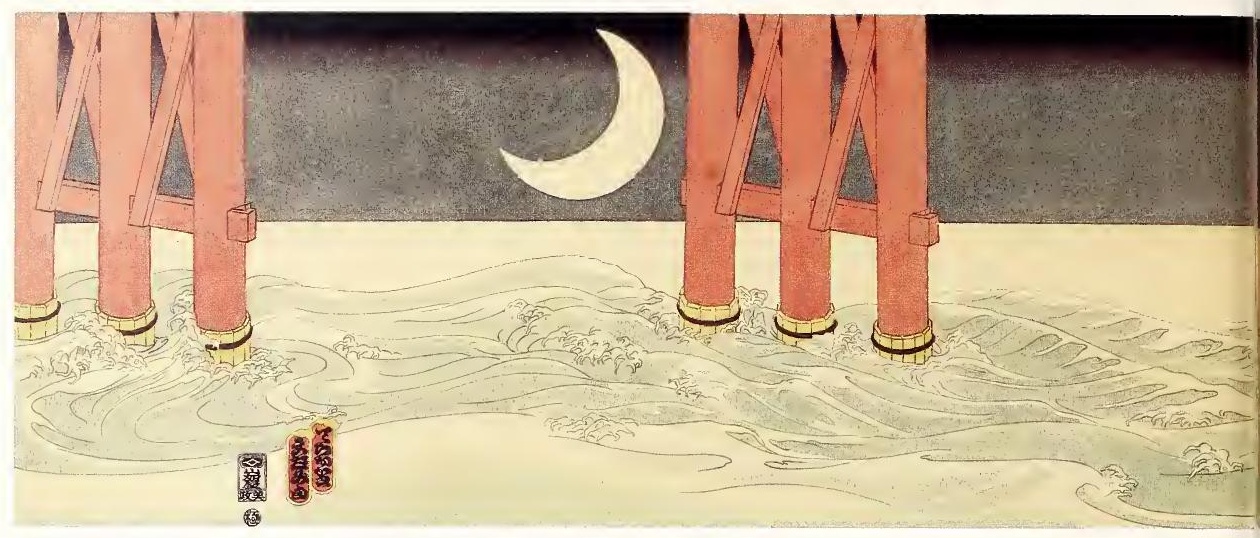

Figure 3 Masami Teraoka, Santa Monica Pier, 1975.

Watercolor on paper, $27.9 \times$ 139.7. Newport Harbor Art Museum, Newport Beach, California; purchased by the Acquisition Council with a matching grant from the National Endowment for the Arts. allows ample room for the ambiguity of his personal relationship to the journey. He is congenitally, dispositionally, "out of place" and "on the edge." The strategy allows him multiple voices and points of view. It offers him varied guises for his role as transformed, metamorphosed pilgrim and compelling metaphoric forms for the awesome darkness that he encounters as the pilgrim. His role is participatory. And perhaps the artist's most compelling transmutation of identity comes from a blend allowed by experimentation with priest and fisherman roles: the catfish in love, the spiritually powerful outsider searching for and rewarded with love.

Masami Teraoka is the catfish, resident of dark waters - by definition, a being at home in the depths. Nuzzling with his blond beauty in the Hawaiian surf (New Waves Series/Catfish Love, 1992; no. 22). Gleeful in her protective embrace as the couple glance back toward the deflated samurai/snorkeler suitor (Hawaii Snorkel Series/Catfish Enwy, 1993; no. 26). How did this transformation from kimono-clad beach-goer to whiskered catfish take place?

In central Japan five kilometers off the north shore of Lake Biwa is the foliage-covered granite protrusion called Chikubushima. It is a tiny island, only .08 square kilometers in area. Far beneath the island is the abode of the catfish, namazu. This is Teraoka's mythic homeland. Lake Biwa lies a few kilometers to the east of Kyoto, separated from the ancient capital by a mountain range. In the late eighth century the Japanese court moved north from Nara to the place now called Kyoto. The move involved not only the relocation of a center of government, temples, and shrines; it also required the relocation of sacred topography, that vital function of the religious imagination, which reads numinous meaning into natural landscape. 



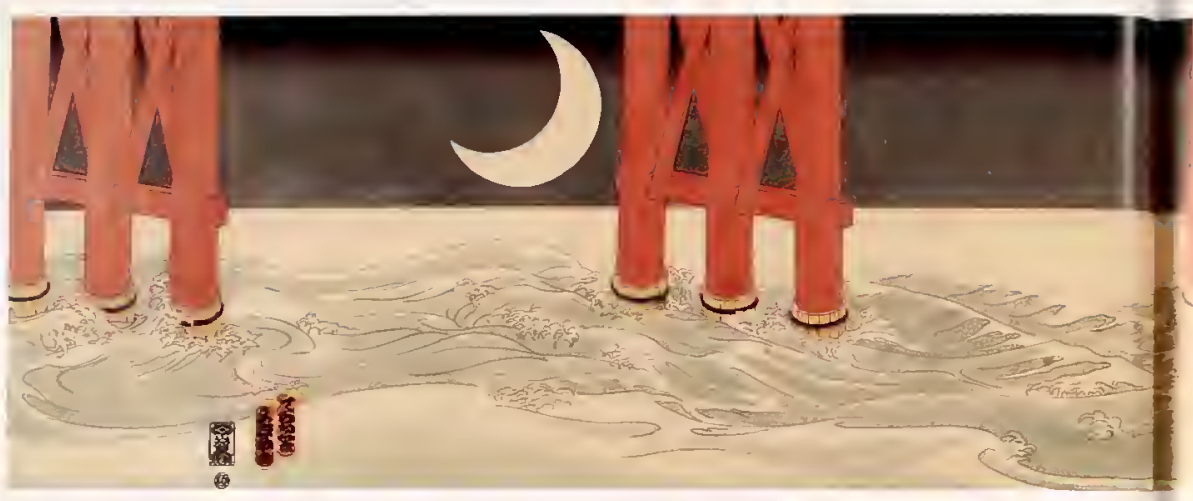

Figure 3 Masami Teraoka, Santo Monica Pier. 1975 Watercolor on paper, $27.9 \times$ 1397. Newpopthator Ait bor Ar Museum, Newport Beach. Califoma: purchased by the Acquisition Council with a matching grant from the Natonal Endowment for the Arts

allows ample room for the ambiguity of his personal relationship to the journey. He is congentally, dispositionally,"out of place" and "on the edge." The strategy allows him multiple voices and points of view. It offers him varied guises for his role as transformed, metamorphosed pilgrim and compelling metaphoric forms for the awesome darkness that he encounters as the pilgrim. His role is participatory. And perhaps the artist's most compelling transmutation of identity comes from a blend allowed by experimentation with priest and fisherman roles: the caffish in love, the spiritually powerful outsider searching for and rewarded with love

Masami Teraoka is the catfish, resident of dark waters - by definition, a being at home in the depths. Nuzzling with his blond beauty in the Hawailian surf (New Woves Serres/Catfish Love, 1992; no. 22). Gleeful in her protective embrace as the couple glance back toward the deflated samurai/snorkeler suttor (Hawail Snorkel Series/Catfish Envy, 1993; no. 26). How did this transformation from kimono-clad beach-goer to whiskered catfish take place?

In central Japan five kilometers off the north shore of Lake Biwa is the foliage-covered granite protrusion called Chikubushima. It is a tiny island, only .08 square kilometers in area. Far beneath the island is the abode of the catfish, namozu. This is Teraoka's mythic homeland. Lake Biwa lies a few kilometers to the east of Kyoto, separated from the ancient capital by a mountain range. In the late eighth century the Japanese court moved north from Nara to the place now called Kyoto. The move involved not only the relocation of a center of government, temples, and shrines; it also required the relocation of sacred topography, that vital function of the religious maginatıon, which reads numinous meaning into natural landscape.
Certain locations are understood to be abodes of sacred presence. And yet others are perceived as representing in microcosm total sacred cosmologies. Mist-shrouded Chikubushıma presented itself to the newly arrived neighboring court, its priests and geomancers, as a site obviously imbued with meaning. Literary sources suggest that from about the ninth century Chikubushima was understood in several ways: as a microcosmic representation of Japan within a vast sea; as the "earth" within a cosmic sea; or, more specifically related to Buddhist thought, as a foundation element in Mount Sumeru, the axis mundi in Buddhist cosmology. The origins of the island are, for our purposes, especially telling. Initial narratives speak of a dragon grasping its tail and spinning seven times. Then within the area circumscribed by its churning form, the mass that is now the island began to congeal or coagulate. A Japanese ouroboros, the serpent biting its tail to form a whirling, creative ring. Its body dark and light. Maddeningly ambivalent in purpose. A source of both construction and destruction. No simple "goodness of creation" story here. The dragon was a Chinese import. Almost from the inception of the Chikubushima creation story an indigenous denizen, the namozu, the giant catfish even now found in the lake, supplanted the dragoris role in the narrative. Some versions of the story say that the catfish previously dwelt in Saruzawa Pond in the heart of Nara and moved north with the imperial household. The catfish resides beneath the island, a source of incredible power, its squirms and shifts reverberating throughout the realm. It exists in a kind of sacred tandem with the Buddhist deity Benzai-ten, goddess of eloquence and intelligence, favoring watery environs. In India, under Hindu guise, she was Sarasvatı. Residing in a temple on the island, Benzai-ten uses catfish as her messengers. Her relationship with them and with the principal catfish is one of great affection. This is likely, too, an echo of the fermale as complement to the strong, sometimes impetuous, actions of the primal male form-a counterforce of cunning beguilement and seduction to protect the created world from the inherent. 
cataclysmic aspects of the catfish personality. For his movements, while creative, also cause earthquakes. A female deity derived from Indian sources and a giant catfish: this was how the imagination of myth worked out the balance of cosmic forces in ninth-century Japan.

The notion persisted and served as a vital metaphor in Japanese political life. Arguably the best-known painting of a catfish is the ink monochrome image of a man gingerly poised at water's edge with a hollowed gourd in hand attempting to capture or subdue a catfish. Created in the fifteenth century by the Buddhist artist-monk Josetsu (flourished ca. 1386-ca. 1428), the painting, with appended inscriptions by thirty-one Buddhist priests, has long been presumed, at the very least in the popular imagination, to be the visualization of a complex Zen riddle. Recent scholarship, while not discounting that interpretation, offers the more prosaic explanation that the work may have been painted as a kind of emblem of authority for the shogun Ashikaga Yoshimochi (1386-1428). The ability to subdue the wily catfish is the symbolic equivalent of mastery over the forces of the earth.

When political power was moved from Kyoto to Edo (now Tokyo) at the beginning of the seventeenth century, following the exercise of realpolitik, the namazu also relocated. More accurately, he bilocated. For while remaining a force under the waters of Lake Biwa, he was also known to reside under the compound of the shrine of Kajima, some distance to the east of Edo near the Pacific shore. The notion of a watery abode was now a less central part of the visual symbolism. A designated sacred stone (kaname ishi) within the shrine compound was said to be connected to the depths of the earth; the stone touching the namazu's back, subdued him. On the second day of the tenth month in 1855 the all-important spiritual connections were short-circuited, and a violent earthquake caused widespread destruction in eastern Japan. Within days of this event and continuing for some months hence, printmakers did a booming business in images of namazu. Mostly cartoonlike renderings of the giant fish being humored and/or subdued, these images apparently functioned as talismans to placate and ward off future disaster.The earthquake occurred in the middle of a decade of extraordinary political change for Japan, a period that marked in fact the advent of a multileveled opening to the West. The twisting and shifting namazu was destabilizing more than land mass; he was the symbol of the power that rends societies.

Just a few decades after the earthquake, power in Japan had passed to a new class of 


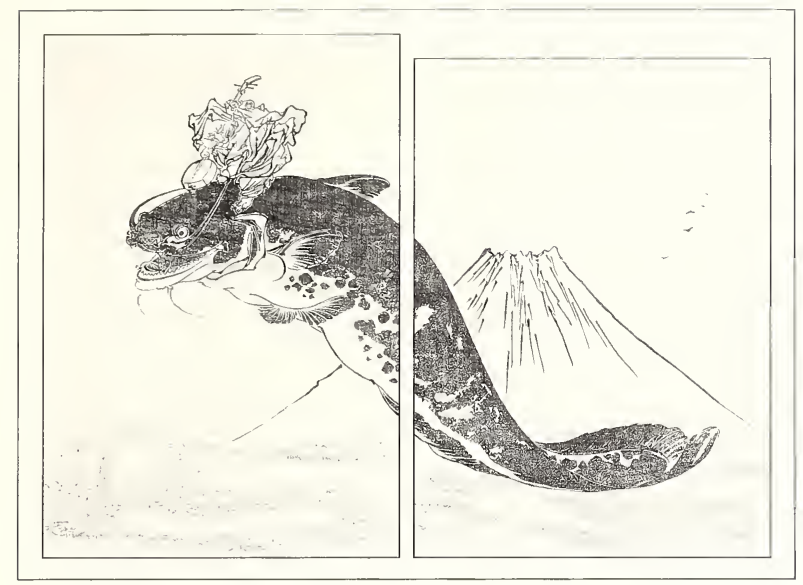

Figure 4 Kawanabe Kyosai (183|-1889), Cat on a Flying Catfish, from "Kyosai's Rambling Drawings: First Series" (Kyosai manga shohen), 1881. Sheets from a color woodblock-printed book; covers: $22.5 \times 15.2$. British Museum, London.

politicians and bureaucrats who were emulating and adapting various forms of Western governmental structures. The iconography of the catfish was secularized. No longer some invisible force lurking beneath the earth, the namazu came to symbolize a new ruling class. The promise of an age of renewed political integrity was unfulfilled, and corruption of the bureaucrats was the subject of biting satire. In more than a few print cartoons, the awesome power of the namazu was depicted as subdued by the seductive power of the geisha (fig. 4). To neatly balance the anthropomorphic political attributes assigned to the catfish, the geisha was often shown as a wailing cat attired in a kimono.

The namazu languished in this century until Masami Teraoka realized that his own resemblance to the droopy-moustached and shiny-eyed creature was more than skin-deep. Now the catfish becomes the artist's most informative doppelgänger. The structure of his internal search for self-definition seemed a natural correspondence to the complicated personality of the great mythical fish. In his various catfish appearances in "Hawaii Snorkel Series" (see no. 26) and "New Waves Series" (see nos. 16, 17, 22), the artist finally discovers a way to break free of the shackles that impeded his progress in lust/love at Venice Beach. He does this by emphasizing his "otherness."'The thwarted suitor in Hawaii Snorkel Series/Catfish Envy is, after all, a Kunisada-esque Japanese male. With allowances for personal appearance specifics, that was the Teraoka of Venice Beach. Ironically, Teraoka has become even more profoundly Japanese in his new ichthyological personality. The catfish is the submerged creative force that has the potential to shake things at their core, a definition that fits Teraoka's role of observer/change effector. And by positing a pilgrim who, by definition, must swim in the waters of desire, he acknowledges that his journey is through the flesh. 
In the symbol and myth systems of various cultures, the fish is often ascribed the attribute of licentiousness. In accepting this fundamental trait, there are no more loving descriptions of the complications of fish desire than those found in the ancient Buddhist jataka tales. These narratives tell of episodes of miraculous intervention by the historical Buddha during his preincarnational existences (previous births). In one tale, a fish compelled by overwhelming desire for his wife pursues her through the waters and finds himself trapped in a net. As he is raised and set in the fisherman's boat, the Buddha passes by, hears his plea, and sets the fish free. The fish had only one concern: it was that his wife might misconstrue his absence as an instance of infidelity.

Multiple transmutations have occurred between the life of the little netted fish, the appearance of the creator/namazu in Lake Biwa, and Teraoka's assumption of the catfish identity, but richly textured mythological constants are found at each stage of the symbol's development. The anxious little fish and the Teraoka/namazu in childlike ecstasy are the same in their desire not to be separated from their primary female. But they are unable to exist outside of their fish nature. Teraoka melds this notion of identity with the curious phenomenon of catfish pilgrimage. If the great fish can miraculously travel from Saruzawa, to Biwa, and to Kajima, the logic of myth is not confounded but somehow fulfilled if the journey continues across the Pacific. The catfish is a big, blissfully coddled, oversized toy by the time he arrives in Hawaii. The artist would prefer to interpret the namazu's potential as destroyer not at the physical but at the hermeneutic level: challenger to established thought patterns.

The scene of catfish and beauty embracing in sun-drenched surf has allowed the artist to complete a fascinating movement of the imagination. Teraoka seems to have found his mythical match, pushing his self-evident identity as "other" to a primal type. The bumbling, lusting, grabbingfor-scraps-of-integrity figure of Venice Beach has resolved his awkwardness at an elemental level.

The namazu is a dark, creative, submerged force lured into dazzling light. But closure is premature. We note that our beauty practices safe sex even, or especially, with catfish. The condom is a clinically rational barrier that skews the perfect symmetry of yin and yang. The serpent biting his tail tastes latex. AIDS has preceded Teraoka/namazu. There has been a thunderstorm at the birthday party. A sickening one-upmanship that takes the edge off the artist's miraculous transformation. 


\section{Dark Forces}

Teraoka, the night fisher, has more on his line than the catfish. And again, he imaginatively excavates and transforms his cultural memory for clues. When disease, decay, and political chaos engulfed Japan in the late Heian period (794-1 1 85), the world seemed truly at an end. The Buddhist notion of the final age (mappo), an inescapable time of lawlessness and corruption that would precede a cataclysm, was, in the eyes of believers, being played out. Yet for the engulfing sense of anxiety and the apocalyptic readings given to all untoward events, the imagined cosmos maintained an order. The realms of existence, from the pits of Hades to the palaces of an imagined Paradise, were visually imagined in a vertical fashion. There was a hell, but it stayed, generally, in its visualized or imagined place. Intrusions of the lower forces into the upper realms - that is, chaos in the imagined cosmology - were uncommon.

In the late fourteenth and early fifteenth centuries, religious iconography does begin to show strange demons prowling the earth, usually subdued by clever monks or warriors. In the early eighteenth century, a rogue political act captured the imagination of the nation. Visual, literary, and theatrical recordings of the event tapped a deep vein in the public consciousness and would be forever emblematic of the double forces of attraction and fear engendered by chaos. Asano Norigana (1665-170 I), lord of Ako, a castle town on the Inland Sea to the west of Himeji, was invited by the shogun to Edo to participate in special New Year's ceremonies. He was to be one of the shogun's representatives assigned to receive the official New Year's greetings of the imperial entourage dispatched from the court in Kyoto. Honored but inexperienced in the intricacies of official protocol, Asano sought the advice of the shogun's retainer, Kira Yoshinaka (1641-1703). Kira was arrogant and gave him short shrift. This so enraged Asano that he drew his sword, a gesture that, because it took place in the shogun's castle, was a capital offense. Asano was immediately stripped of his holdings and title and ordered to take his own life. With Asano's death his loyal retainers, led by Oishi Yoshio (1659-1703), became what were known as ronin (masterless samurai). They plotted a vendetta and attacked Kira's residence in the predawn hours of January 31, 1703. A cowering Kira was discovered hiding in his storage house. He was slain and decapitated, and his head was placed on the grave of Asano at Sengakuji temple. The avenging 


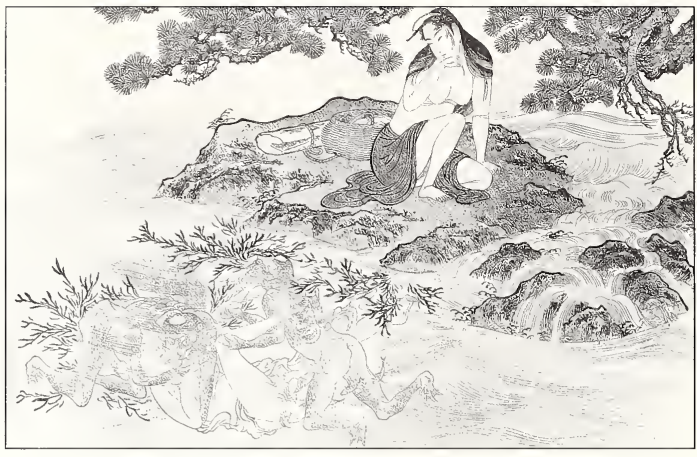

Figure 5 Kitagawa Utamaro (1753-1806), Abalone Diver Raped by Kappa as Her Companion Looks On, from Utamakura (Poem of the Pillow), 1788. Sheet from a color woodblock-printed book; about 25.4 $\times 36.83$. British Museum, London.

samurai, known as the forty-seven ronin, were tried and ordered to commit suicide.

The incident was fabulous grist for the newly formed arts of the theater and print to assimilate, valorize, and explore for levels of meaning. The public was thrilled by the noble act of revenge against what was perceived as legitimate but evil authority. Rules of censorship precluded any reportorial references to the event. Thus, in prints, paintings, and plays, this amazing occurrence was recast in medieval times. The public clearly understood the codification. The arts placated an appetite for voyeuristic rejection of an established social code. Yet the difficult decision to order the deaths of these ronin was reached because the hard-earned stability of the Edo period had been directly challenged. Images of hooded warriors raising ladders up the moonlight-washed walls of what viewers understood to be Kira's residence provided a new metaphor for the Edo period. From the dark of night emerged the pleasure of revenge and the risk of chaos. It was not long before ancillary images became popular. Ninja, the black-clad masters of martial arts, magic, and assorted subterfuge, were increasingly popular subjects of the woodblock print. These spies and provocateurs were employed by contending warlords in the century of civil strife that preceded the unification of the Edo period. Stealth, deception, and penetration of enemy territory were their particular skills. The incident of the forty-seven ronin was the prototype of an honorable action taken in stealth and in the dark, but ninja prints soon became an exercise in prurience. They depicted scenes of rape, the master slain and his consort violated. Frequently they offered the titillation of an intruder peeking into the bedchamber to observe the resident couple engaging in sex. The offering to the public imagination was not an obvious threat to the public order. It gave a decidedly sexual cast to the dark forces.

By the close of the eighteenth century the visualization of another fantasy gained popularity. In the short step from ethnographic observation to voyeurism, female abalone divers became a subject in demand in prints. Young women, seminude as their occupation required, were 
depicted in idyllic coastal settings, diving, lounging on rocks, arrayed in various poses. The artist and audience were most interested in the attendant sexual risks and benefits. A diving beauty captured and raped by kappa, weird, saucer-headed, froglike creatures who inhabited marshy areas (fig. 5). Or wrapped in compliant ecstasy in the probing tentacles of an octopus. With his own octopus, Teraoka recalls a famous image created by Katsushika Hokusai ( 759 - I 849). In Hokusai's Pearl Diver and Two Octopuses, 1814, the encounter with the octopus suggested, albeit in the vocabulary of the voyeur, the possibility of a blissful union with nature. But like the rape images, it was a fantasy projection rather than a symbolic accommodation to reality. The newly popular imagined threats from watery depths and darkness lacked the fundamental orthodoxy of the world-creating catfish. He was a figure of respect, the symbolic manifestation of a worldview that expected a natural cycle of building up and breaking apart. The namazu was not, could not be, a misogynist. He lived in a delicate tandem with women.

\section{Genesis}

Teraoka's various versions and recyclings of the octopus/woman prototype in his innovative union of catfish and blond beauty on Hawailan shores have, if taken within the general boundaries of Japanese myth-fantasy, an independent integrity of meaning. But these images are also a rehearsal for the artist's consideration of a fundamental Western event: Eve's seduction by the serpent. He has pursued the protean creation creature in its several guises and in its equally diverse relationships to the feminine: creative, protective, destructive, dark, devouring, and lusting. We have seen a Japanese woman and an octopus, a Caucasian woman and an octopus, without and with condoms, before and after the Fall. We have followed the namazu from the deep lake waters of central Japan to consummated love on a Hawaiian beach. After arriving in the West enveloped in the persona of one creation-myth principal, the namazu, the artist ventures into a Western myth of male and female union following his logic of transmuting pilgrim identities. In the revealing transitional image London Tube Series / Camden Eve (see no. 30), Teraoka appears as a proactive ninja. As Eve contemplates the fruit offered by the serpent, ninja/Teraoka hurls condoms, rather than the 
usual assassin's knives, to rescue her from the fatal encounter.Teraoka's optimistic intervention will later be confounded when Western myth inhabits his imagery.

Serpents abound as Teraoka's symbols of the AIDS plague. They are employed in their quintessential role as dark, entangling, poisonous, and deceptive forces. Their inherent phallic shape compounds the metaphor of frustration with the corrective sublimation of what seems to be an original, unmanageable drive (see AIDS Series/Harajuku Boy, 1988, and AIDS Series/Punk Woman, 1988; nos. 7, 8). But these representations are in the "floating world" vocabulary. The Hawaiian transmutation as namazu has set the stage for Teraoka's next arena of interest: the Western myth of Creation and Fall.

Teraoka is a master of surprises. The playful portrait of Kunisada in which the master is observed startled by the substantial and well-formed backside of a beauty in Hawaiian waters (Hawaii Snorkel Series/Kunisada Edipsed, 1993; no. 24) is now more than a humorous image of a flaccid-skinned old man, awkward and out of sync in a strange new world. The image, in retrospect, seems to have signaled an impending change in subject and, ultimately, a change in teachers. In the "AIDS Series" and related works, Teraoka approached a horrifying issue with suitably grotesque but obliquely theatrical images. Like Kunisada, in time-honored ukiyo-e style, the artist encoded a sensitive contemporary issue in the guise and setting of another age.

Teraoka, self-portrayed as a cautious observer/ninja, aptly describes the artist's tentative approach to a new subject and its iconography. The serpent of the Genesis account is the most formidable of the dark forces seen thus far in Teraoka's shifting vocabulary of creative/destructive powers. The threat from darkness has been expressed previously as social chaos in general, but more pointedly as sexual assault. There are lascivious leviathans who emerge from the depths to take women. Or there are dark-clad ninja who leer at the moment of male/female intimacy. Sexual knowledge is seized directly or studied and "learned" by an observer. In either case it is an act of acquiring power. Perhaps, beyond the many levels of salaciousness and brutality associated with voyeurism and assault, there is expressed in this tradition of imagery a need to peer into the moment of unity and divine a harmony lost at the Garden of Eden. In a sense, Teraoka's awareness of the Fall precedes his use of Genesis imagery. AIDS and latex-wrapped love had been his overarching symbol for a relationship gone awry, of a paradise lost. The sexual union, both real and 
mythic, has been disrupted and called into question as a source of knowledge and power.

In London Tube Series/Camden Eve the artist is on the edge of new discovery and expression. He embraces a big chunk of rich and fractious meaning. The Genesis account, intuited or understood by Teraoka, is indeed a creation story of another order. It is intentionally polemic in repudiation of the various origin narratives of other Near Eastern religions. It posits a creator beyond gender. It thus finds sexual union or its ritual re-creation an inadequate metaphor for creation or for propitiation that might set right periods of chaos. The Hebrew authors suggest that the relationship between creator and created is a compassionate covenant. And freedom of choice lies at the heart of the relationship. Cautioned against eating of the fruit from the tree of the knowledge of good and evil, Eve and Adam succumb. The knowledge they reap is the knowledge of mortality.

In Teraoka's fluid and ever-developing myth vocabulary, the Genesis serpent might lay claim to Asian origins. He might remind Eve of their long and many-guised relationships. The serpent could suggest that he was the spinner, the ouroboros creating a whirling, coagulating circle in Lake Biwa, the creator catfish to Eve as the goddess Benzai-ten. Now with his tail out of his mouth, the serpent can speak and offer Eve the great temptation. There is no longer a need to be linked

Japanese woodblock prints are conveniently identified as the works of specific artists, whose printed signatures and seals they often bear.The reality of woodblock print production was actually far more complicated. Design, block carving, and printing were the three main stages of printmaking. The process was orchestrated by a publisher who was the ultimate arbiter of theme, color, and composition. He was at financial risk in his attempts to predict audience taste or to set trends. The skills of the block carver and printer were essential to rendering or even enhancing the artist's intentions.

An artist's design included color suggestions, but its essence was the black ink drawing. This drawing on semitranslucent paper was pasted onto a cherry or boxwood block and carved in relief. The block was inked and paper was pressed onto the block, producing the image created by the designer. Designs in multiple colors required many blocks carefully registered so that a clear image with no unintended overlapping colors or lines was produced. 
in this male/female myth tandem. The serpent offers to pass on the power of creation, the power of omniscience.

Teraoka is an artist. He is not dealing in religious tenets but in search of images to inform him in a quandary. And no single Japanese-born image allows him to convey with the force he desires the pain attendant on misdirected purpose, on ruptured relationship, as does the universally recognizable image of the Eden couple in collusion with the Great Seducer. And the seduction is not male of female or female of male so that reunion in some essential order may be reconstructed. The flawed choice made by both is for knowledge over the possibility of the loving relationship of creator and created. An act of disobedience precipitates expulsion from the Garden. Reunion is always a possibility, but not in the expression of any sort of fertility metaphor that re-creates a preexisting idyllic order.

The option for knowledge and its horrific consequences are at the thematic core of Teraoka's "Adam and Eve" series. In paintings redolent with smoldering apocalyptic fire and spattered, dripping blood, the artist creates a sarcastic parody of sex-as-knowledge by uniting the primal couple with computer equipment. Teraoka's presentation of the vulture-picked corpses of Adam and Eve (Adam and Eve /Mousetrap, 1995; no. 36) assures the viewer that the cozy embrace of the catfish and the beach beauty was an idyllic but naive resolution. The Adam and Eve who seized the power of creation are now trussed to the limbs of dead trees by the cords of computer mouses. Thrust between their legs are blank-screened computer monitors. The mouses dangle from cords like sterile fruit or dead spermatozoa. Phallic-headed vultures probe genitalia.

In Eve with Three Blind Mice, 1995 (no. 37), with the Roman Colosseum ablaze in the far distance, Eve, atop a pedestal like a work of sculpture, holds three disconnected computer mouses and a keyboard. Blood of uncertain origin drips randomly on the surface of the painting Or, in yet another image (Adam and Eve/Surge Protector, 1995; no. 34) the couple cower nude, except for Eve's Rollerblades, and seek shelter as bloody lightning crackles through a doorway. She covers her head with a computer keyboard while he sheathes a computer mouse with a female condom. An image of ultimate absurdity?

Media Bacchanalia, 1995 (no. 39), a painting of massive scale, offers a scene distinctly reminiscent of Golgotha. Faceless clothed male and female forms are posed on two trees as a 
throng of reporters and media types thrust microphones and point cameras in their direction. Mingled with the group are the skeletal dead and decomposing. Fire plays at the feet of the crowd and consumes the distant landscape. Blood drips everywhere. Exotic creatures (perhaps endangered), lizards, hyenas, and vultures mix with the querying crowd. This is a bestial and human combination clearly comfortable together.

The source of chaos is unclear. It is offered as the state of affairs: violation, probing, poking, and serpentine forms - all familiar from other Teraoka images. But the modest degree of assurance and distance offered by the stage setting of a Kabuki play is no longer visible. We can no longer dawdle in the humorous world of double entendre and obscure historical reference. This is a harsh vision.

Masami Teraoka, the funny, awkward fellow of Venice Nude Beach/Self-Portrait, is gone. So are the ripe, voluptuous sand maidens. We are now in the realm of wailing and gnashing of teeth. The multiple transformations and transmutations of the observer/participant artist have ceased. Our man and woman are Everyman and Everywoman. Bodies take on an preternatural luminescent glow. It is a cold light.

Information masquerading as wisdom has deceived us. The computer screen is a hightech peep show. There is, after all, a final transformation. The serpent is a rubber-covered wire wrapped around the desiccated tree.

Teraoka has been gradually propelling himself from a circle into a linear trajectory. From myths of union, searches for wholeness, to a point beyond. For now he can paint most fiercely about the wrong choice, but is convinced about the necessity of choosing. 


\section{-2य = (ग)}

25 5*bar ans
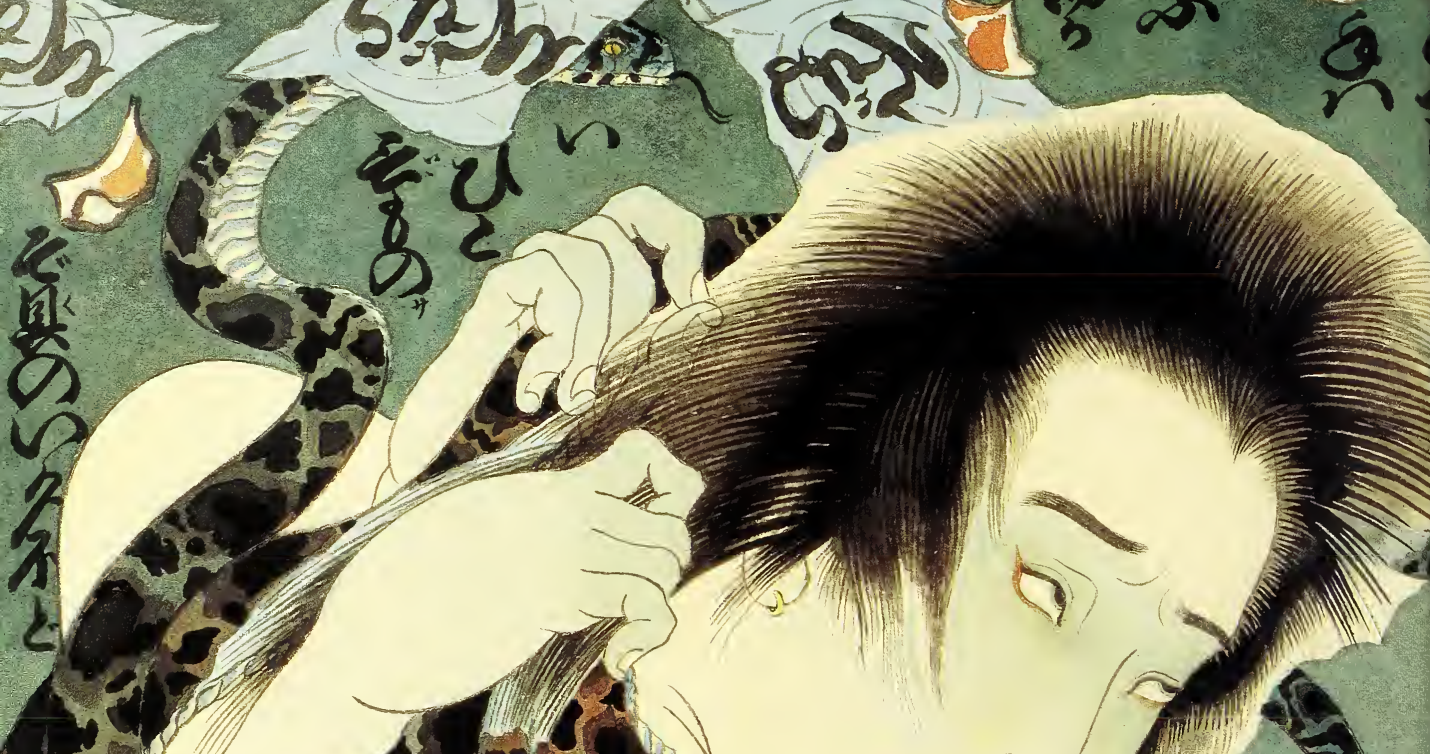

5
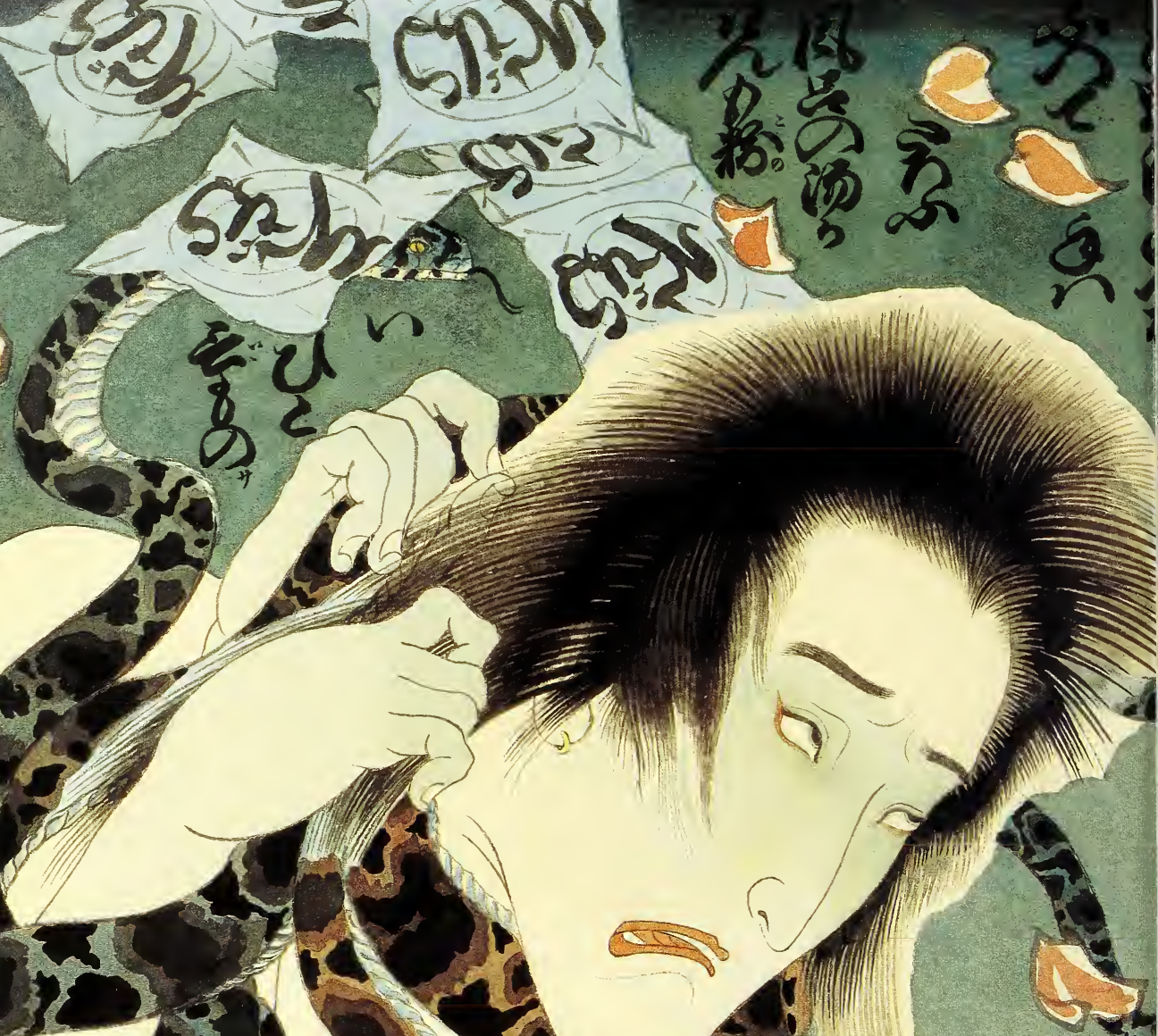


\section{PULP FICTION AND THE FLOATING WORLD}

\section{ALEXANDRA MUNROE}

N 1974 Masami Teraoka created a series of watercolor paintings entitled “McDonald's Hamburgers Invading Japan." Drawing on stylistic conventions of the Japanese ukiyo-e woodblock print and incorporating references in the tradition of American pop art to the bizarre banalities of mass consumer culture, this series established Teraoka as a contemporary master of mannerist aesthetics. Folly, eroticism, and decadence pervade his theatrical narratives, and elements of disquiet threaten their decorative harmony. In McDonald's Hamburgers Invading Japan/Geisha and Tattooed Woman (fig. I), for example, a modern Caucasian woman with an allover tattoo of cherry blossoms slurps from a bowl of noodles while a classical japanese courtesan, peeping around the sliding door like a voyeur in a traditional erotic scene, shows exasperation at learning how to eat an American hamburger." "Should I just bite into it?" she wonders aloud. Although the artist says he originally intended satire, her words forebode an alarming outcome.

Teraoka's dramas about life at the millennium reflect with acerbic wit the eternal human conditions celebrated in pulp fiction and the "floating world": sex, glamour, violence, petty heroics, retribution, and the afterlife. Culture and commentary have always been the subject of Teraoka's work, but his deeper purpose is creation. What he paints asks of us the question: How to survive? His answer, over and over, is through Art.

The graphic sources of Teraoka's mature work (he came to his signature style at the age of thirty-eight) are generally attributed to his "being Japanese" — as if ukiyo-e were a pervasive tradition during the 1930s and 1940s when Teraoka grew up in a remote harbor town mobilized for

Masami Teraoka, AIDS Series/Harajuku Boy (detail), 1988. See no. 7. war, or as if this art form of the Edo period (1615-1868) were commonly pursued by fine artists of Teraoka's generation. Both are misleading assumptions. In fact, Teraoka developed his interest in ukiyo-e 


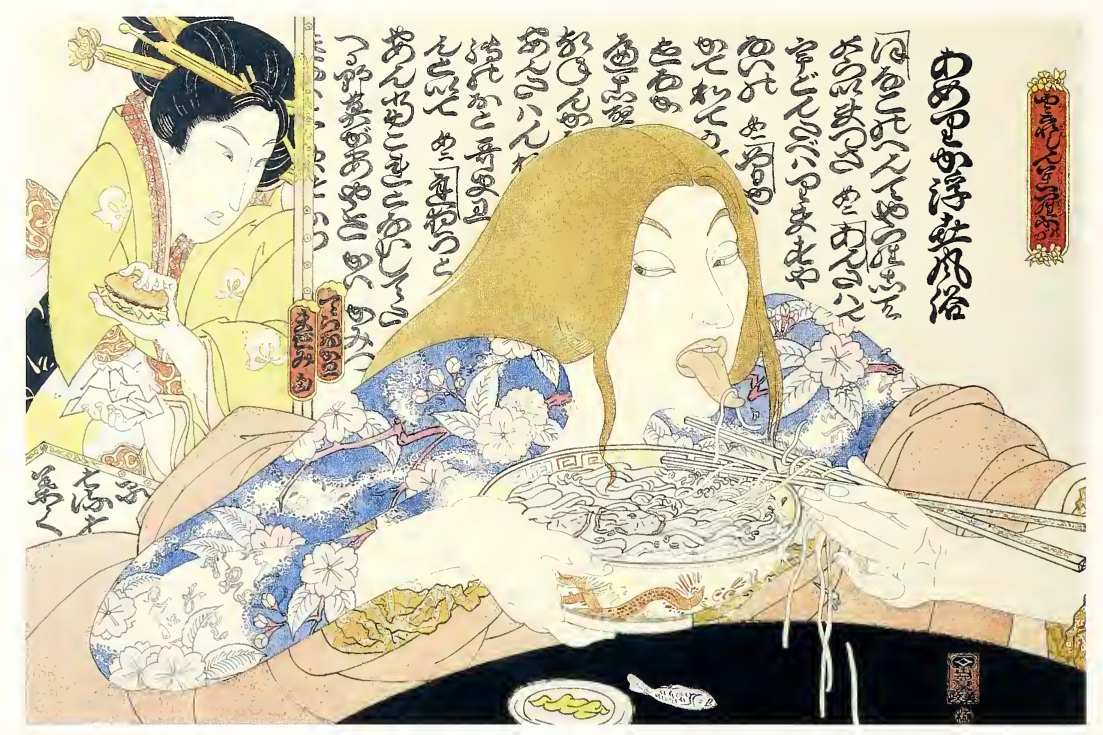

Figure I MasamiTeraoka, McDonald's Hamburgers Invading Japan / Geisha and Tattooed Woman, 1975. Watercolor on paper, $36.2 \times$ 54.6. Collection of Peggy and Richard Danziger: prints while he was a student of contemporary American art in Los Angeles. He first used the term in the title of an erotic drawing suite in 1971, ten years after his permanent move to the United States. Removed in the most obvious ways from the original culture and historical period of ukiyo-e, Teraoka appropriated the classic style of such woodblock masters as Utagawa Kunisada (1786-1865) and Katsushika Hokusai (1759-1849) as both a formal and critical device. Although his position in the broadest lineage of the ukiyo-e tradition is arguable, Teraoka's purpose has never been to preserve a nativist style. In fact, his medium and format are not derived from Japanese printmaking at all: his works are executed in watercolor on Rives BFK paper with a variety of brushes. Teraoka's idiom is contemporary large-scale figurative painting. He explained in a recent interview, "One side of me wanted to acknowledge my cultural heritage; the other side pushed me to break out of a tradition, to come up with my own vocabulary. American art's institutionalized idea is not to follow anyone's mold, but to get away from any sort of influence."

Teraoka approaches ukiyo-e as a bricoleur. It offers him possibilities — narrative subject matter to play out his ideas and a rich decorative aspect to play out his aestheticism. He uses its convention of humor to parody the culture clashes of the East and West and its love of erotica to confound the strictures of modern sexual morality. The upheavals of the late twentieth century - mass consumerism, cultural wars, ecological ruin, and AIDS (acquired immuno- 
deficiency syndrome) - are presented through a drama of conspicuous salaciousness. By casting these contemporary issues in the "floating world" guise, Teraoka consciously recalls ukiyo-e's subversive intent to criticize the bureaucratic corruption and social chaos of the late Edo period. Critic Gerard Haggerty has written of Teraoka that "the aura of Edo's past dignifies the artist's protest, and delays the explosive shock which accompanies his broad parody."2

Teraoka's manipulation of ukiyo-e centers on appropriating its devices of "veiled dissent" to critique the tragicomic status quo. The West's fin-de-siècle craze over ukiyo-e's bold, deft imagery celebrated the decorative brilliance of the Japanese print with little knowledge of what ingenious risks the artists took to circumvent government censorship of the visual arts. Numerous edicts banned pornography and images of Christianity and the ruling familyostensibly to control moral, social, or political insurrection. Of these, laws against any depiction of current events were by far the most severely enforced. When officials deciphered Kitagawa Utamaro's (1753-1806) famous triptych The Taiko Hideyoshi and His Five Wives on an Excursion to Rakuto, 1804, as a covert expression of opposition to Tokugawa rule, the artist was sentenced to three days in prison and fifty days of house arrest in handcuffs. (The print offered a sympathetic portrait of Toyotomi Hideyoshi, the flamboyant sixteenth-century warlord who had ruled Japan before being defeated by Tokugawa leyasu, founder of the Tokugawa shogunate, 1615-1868.) The "double language" that artists and publishers devised to thwart the censors - transposing contemporary events to a distant past or inserting special cartouches and punning verses - thus became an essential feature of the Edo-period woodblock print. That Teraoka incorporates these same means of "veiled dissent" identifies him, beyond his artistic choice to adapt formal ukiyo-e conventions, as "being Japanese": his obscure, encoded defiance against cultural orthodoxy, social conformity, and political coercion is founded in the history and practice of Japan's minority spirit of opposition. 


\section{The Japanese Avant-Garde}

During the 1960s and 1970s, several Japanese artists of Teraoka's generation cultivated a hybrid genre of "pop ukiyo-e." Among the earliest to forge this style were Shinohara Ushio (born 1932), a founder of the radical Neo-Dada Organizers group active in Tokyo from 1960 to 1964, and Yokoo Tadanori (born 1936), originator of the internationally acclaimed "Japan style" in graphic arts. Their work shares with ukiyo-e a devotion to erotic imagery, parody, and social commentary. Simultaneously it also reveals mastery of certain formal, conceptual, and critical principles of American pop art - most obviously, the use of "pop" subject matter, drawn from imagery found in magazines, newspapers, television, billboards, and movies, and the use or simulation of "pop" technique, a rendering of imagery derived from the commercial rather than fine art field.

Roy Lichtenstein's Aloha, 1962, exemplifies pop art's radical preference for bright, hardedged forms; flat, decorative surfaces; and banal but seductive representational images (fig. 2). Here, subjective content has been dismissed along with other vestiges of modernist art: the artist aspires instead to a cool and mechanized stylization of mass-produced types, things, and signs. Appropriating advertising, comics, and other forms of mass media, pop artists mimicked their visual languages, their exercise of power, and their values so as to critique the consumerist society that sustains them. Related to this aspect of social criticism were pop's frequent assaults on the heroic antics of the American military and its worship of high technology fostered by the Cold War arms race. Japanese avant-garde artists of the 1960 s responded to these processes of "critical transformation" and modes of sociopolitical critique as they sought to create an art form that conveyed the ambiguity, deceptive complexity, and paradox of postwar Japan in the throes of Americanization. Of course, Teraoka's encounter was intensified by his move to America, where he observed the rise of pop art firsthand.

The avant-garde ideas that had been current in prewar Japan - the role of the artist as iconoclast and agitator in society, the ability to mix literary, visual, and performance art forms to create new genres, and the free adaptation of traditional culture to serve a contemporary idiom - resurged after wartime suppression and, spurred in large part by growing opposition to the conservative rule of postwar Japan, gained momentum in the late 1950s. Leftist demands to 


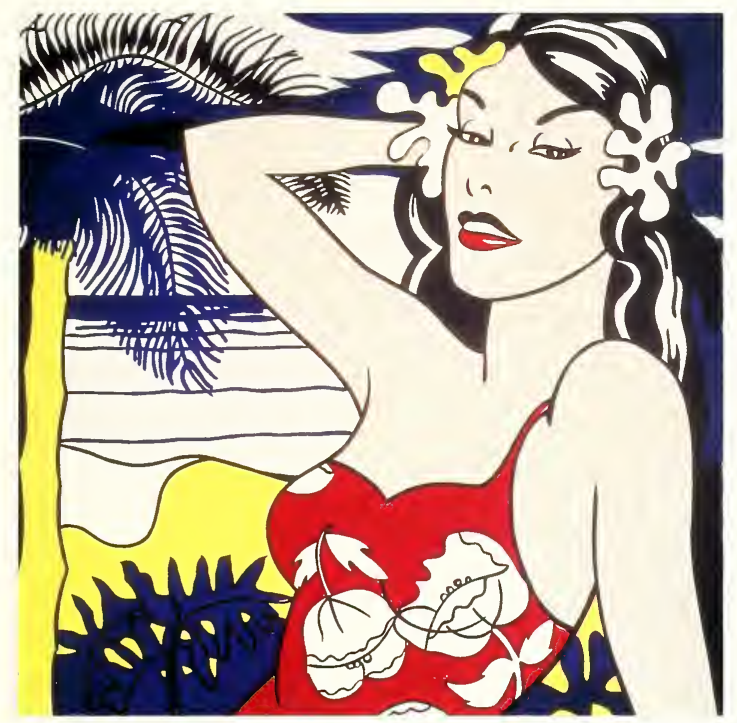

Figure 2 Roy Lichtenstein, Aloha, 1962. Oil on canvas, $172.7 \times 172.7$. Helman Collection, New York.

revise the U.S.-Japan Security Treaty, which gave the United States the right to use Japan as a military base in the expanding ColdWar arena in East Asia, caused a succession of massive strikes and violent demonstrations that culminated in a national crisis in 1960. Beneath the veneer of postwar reconstruction and American allegiance, disillusion with capitalism and mistrust of the West fed an overwhelming Socialist opposition that instigated social unrest and political instability. This confrontation brought into sharp focus Japan's conflicted relationship to its "other," the U.S.A. Young Japanese decried the atomic-age horrors of Hiroshima and Nagasaki, and yet were drawn in their state of deprivation to the world of plenty that the Occupation culture symbolized, including jazz, Hollywood films, and eventually such icons of American pop culture as Coca-Cola, chewing gum, and Marlboro cigarettes. What would become Teraoka's satirical commentary on Japan's rapid Americanization in the seventies (as illustrated by his series "McDonald's Hamburgers Invading Japan" and "3 I Flavors Invading Japan") thus has conceptual roots in the protest movements of the postwar Japanese avant-garde.

Shinohara "discovered" ukiyo-e in 1965, when he came across the work of the lateEdo-period artist Tsukioka Yoshitoshi (1839-1892), a decadent known for his graphic, macabre scenes of ghost stories, sadism, and battles from Japan's bloody past. Horror and cruelty were common themes of popular culture in the late Edo period, as the Kabuki plays, literary fiction, and woodblock prints of the day reflect. Again in the 1960s, it was the country's disturbed mood that brought about this interest in strange horror, reflecting an ambivalent fascination with and 


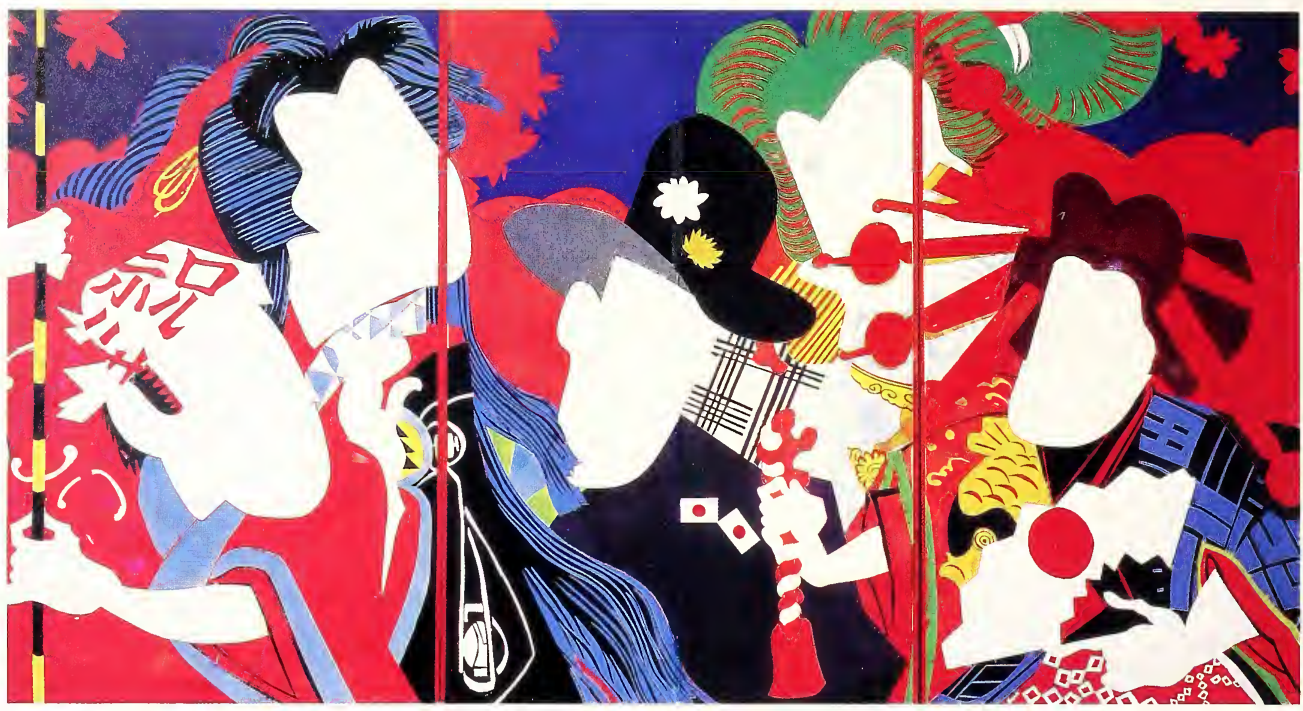

Figure 3 Shinohara Ushio. Doll Festival, 1966. Fluorescent paint, lacquer, and plastic on canvas, $195.6 \times$ 391. Hyogo Prefectural Museum of Modern Art, Kobe, Japan. revulsion against an undertow of violence. In both periods, such expressions were a form of subversive protest against the oppressive social system - late-Edo Confucianism in the former, and the hypocrisy of postwar democracy in the latter. Inspired by the bloody clashes in Tsukioka Yoshitoshi's 28 Murders, 1867, Shinohara embarked on a series of paintings, sculptures, and collages in which he combined contemporary Western with late-Edo-period tales of bloated glory and perverse violence. He exclaimed:

This is it! The image of man and woman killing each other with kitchen knives in a small four-and-a-half-tatami-mat room. The blood splashes on paper walls. Blood boiling, my imagination went wild: If I enlarge this image ten meters square, the area of blood would become incredibly enlarged. Red fluorescent paint envelops the viewer and the scene of cruelty is accentuated by plastic cherry blossoms. ${ }^{3}$

Shinohara's simultaneous references to ukiyo-e and Bazooka comics in his stylized images of cowboys and oiran (courtesans) defined his remarkable genre of hybrid pop (fig. 3). Absorption of the bizarre and overdecorative also informed the work of graphic designer Yokoo Tadanori. In a style that was at once nostalgic and satiric, Yokoo's profane pop juxtaposed 
advertising images of Golden Bat cigarettes and Betty Boop from the Meiji (1868-1912) and Taisho (1912-26) eras with sadistic scenes drawn from Edo-period shunga (erotic prints), set before blazing backgrounds of Mt. Fuji and the Rising Sun (fig. 4). Combining the psychedelic style of sixties rock ' $n$ ' roll culture with the clichéd mannerism of nineteenth-century printmakers like Hokusai and Ando Hiroshige (1797-1858), Yokoo chronicled the splendid sham and decadence of Japanese society much as Andy Warhol (1928-1987) did America's during the same period. His use of ukiyo-e aimed to parody how Japan saw itself through orientalist projections; by composing a portrait of Japan through the distortions of japonisme, he upended its over-Westernized self-image. It is no coincidence that Yokoo's embrace of the burlesque, kitsch, fringe, and supernatural has affinities with the work of his contemporary, Masami Teraoka.

But Teraoka's use of pop and ukiyo-e served other purposes that are unique to his artistry. On one hand, he approached ukiyo-e as a "product." Just as pop art used such iconic American products as Brillo, Ballantine ale, and blond girls, Teraoka recycled popular ukiyo-e figures and motifs as a kind of Japanese ready-made. Working within the context of American pop art, he goes beyond it by reducing it to a referent. "My adaptation of ukiyo-e style is not aimed at exoticism," he has said, "but rather shows how an old ready-made meets a new product of American pop art." Teraoka's use of ukiyo-e was strategic in another way as well. In the anti-aestheticism art environment of Los Angeles in the 1960s, Teraoka did the unthinkable by making art that celebrated a system of highly refined aesthetics. To Teraoka, raised as a member of Japan's merchant society (his family operated a successful kimono fabric store), ukiyo-e was the acme of Japanese taste and style. As contemporary American art was swept up in conceptualism, ostensibly leaving painting and formalist concerns behind, Teraoka adopted a contrarian "pro-aesthetic" stance. "The way I wanted to pursue my painting in the early 1970s," he has stated, "was to get away from conceptual art..., which ignores aesthetics in general." Always the subversive,Teraoka in his hybrid work satisfied the contemporary critique of art not by minimizing but rather by maximizing the bold and the beautiful. 


\section{Teraoka in America}

Although Teraoka's entire artistic career has developed in America, he has remained an "outsider" of mainstream American culture. James Jensen, director of the Contemporary Museum in Honolulu and a longtime supporter of Teraoka's work, acknowledges that it cannot be easily categorized. Jensen has observed that Teraoka's art often parallels but rarely intersects with traditions, movements, or styles current in America. ${ }^{4}$ During the 1970s, Teraoka was appreciated for his satirical wit and technical virtuosity and lauded for "skillfully balancing the dichotomy of his Japanese background and his adopted Los Angeles through the use of a ukiyo-e style."5 But this perception, culminating in 1979 with his solo exhibition at the Whitney Museum of American Art, may ultimately have prevented a deeper understanding and appreciation of his art. He gained fame as an "adept parodist,"' but any assessment of the artistry of his painting was left to Japanese art specialists, and in the United States his work confounded the mainstream by what was perceived as its very exoticism.

With the eclipse during the 1980s of the New York-centered pop, conceptual, and Minimalist art "schools" and the new focus on artists' personal narratives, Teraoka's painting became more widely accepted. Indeed, his standing in contemporary American art has become prominent in recent years. Since 1985 his work has been featured in some fifteen solo and twenty group museum exhibitions and has generated numerous art-critical writings. Whereas earlier interest in his work focused on the wiles of his updated japonisme, it has become both common and fashionable to discuss Teraoka in the context of multiculturalist criticism and identity politics. By questioning the primacy of authorship, originality, and formalism, many minority artists in the mid-1980s sought to picture themselves outside a system that valorized the white, male, Eurocentric lineage of modern art history. As investigations of the "other" became pronounced, Teraoka's sources were praised for being premodern and non-Western. Further, new patterns of immigration created, according to art historian Elisabeth Sussman, a "willingness to redefine the art world in more realistic terms - not as a seamless, homogenous entity but as a collectivity of cultures involved in a process of exchange and difference."'7 A permanent resident of the U.S. since 196 I and a citizen since 1986, Teraoka has unwittingly emerged as a mascot of the Asian-American art discourse. 


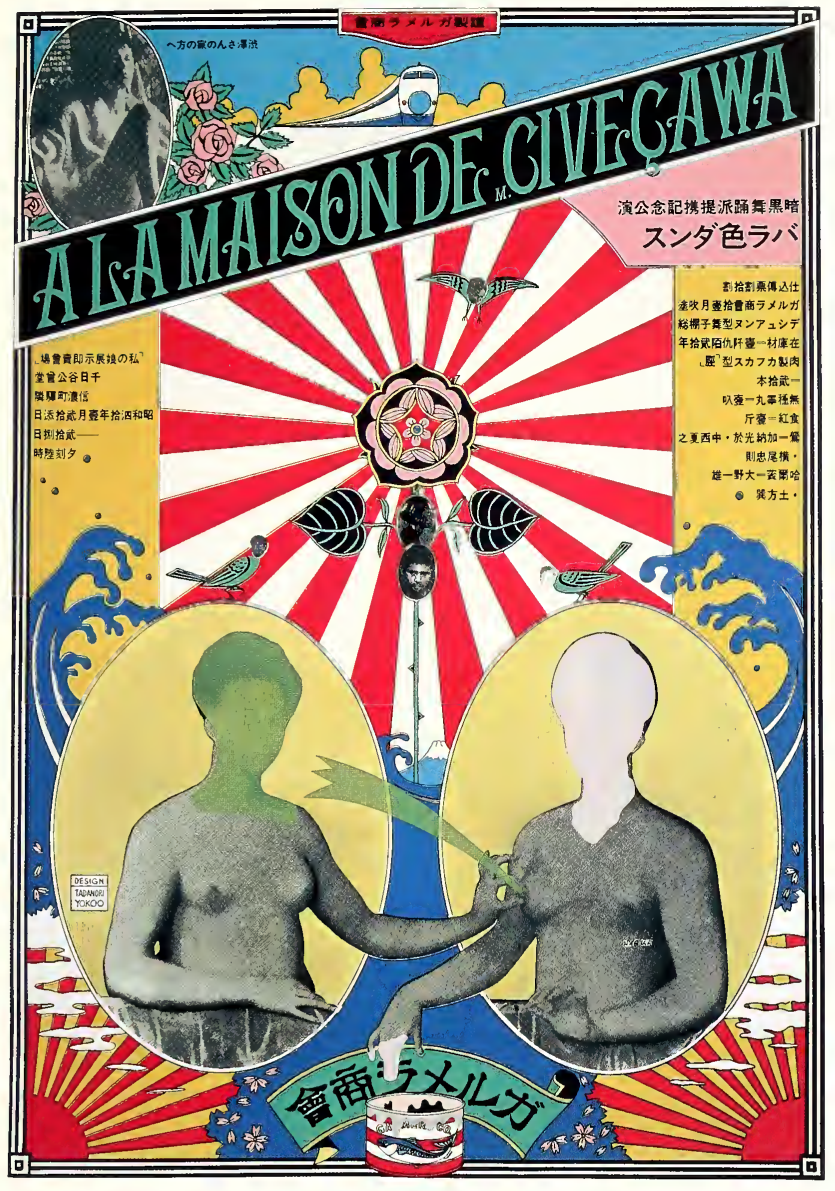

Figure 4 Yokoo

Tadanori, A la Maison de M. Civeçawa, 1966 Silkscreen, $103.8 \times 72.8$ Collection of the artist.

His decision to live first in Los Angeles and, since 1980, in Hawaii has further contributed to the perception of him as an icon of the "peripheral."

Certain elements essential to Teraoka's work are indeed shared by art of the so-called multiculturalist movements. The use of allegory, frequent combinations of image and words, decipherable or not, and an emphasis on culturally specific subject matter characterize the work of such artists as Jean-Michel Basquiat (1960-1988), Pepón Osorio (born 1955), and Hung Liu (born 1948). Like Teraoka, these artists render the exotic stereotypes of their respective Otherness or minorities (African-American, Latino, or Chinese-American) precisely so as to upend them. Their work also tends to combine autobiographical narrative with sociopolitical critique. Teraoka's 1979 New Views of Mt Fuji/La Brea Tar Pits Amusement Park (fig. 5), for example, features his self-portrait 
in a farcical act of survival in the face of ecological doomsday caused by Japan's commercial exploitation of the environment. The work is from a series that parodies Hokusai's famous views of Mt. Fuji and relates a fantastic narrative in which Japanese businessmen purchase the Los Angeles tar pits and move them to Japan to create a prehistoric amusement park. Teraoka, in robes and moustache, makes his precarious way to land walking a tightrope held at one end by a mammoth sinking into the tar pits and at the other by a Kunisada-style courtesan, golf bag swung over one shoulder, who clenches the rope in her mouth. Teraoka carries aloft two lacquer trunks, one marked "to" (East) and the other, "zai" (West) - a wry commentary on the trials of his dual identity.

Work by Masami Teraoka was included in the landmark exhibition Asia /America: Identities in Contemporary Asian American Art, which opened at the Asia Society in New York in 1994. Remarkably, his preoccupation with "resisting assimilation" and other multiculturalist themes has been ongoing since the early 1970s - a decade or two before the show's predominantly younger artists emerged. Curator Margo Machida argued for Teraoka's place in the con-

Figure 5 Masami Teraoka. New Views of Mt. Fuji/La Brea Tar Pits Amusement Park (detail), 1979. Watercolor on paper, $29.2 \times 139.7$. Private collection. temporary Asian diaspora on the grounds that he is representative of artists for whom "the intricacies of mediating a satisfactory relationship with the society and culture of an adopted nation" is a primary concern. ${ }^{8}$

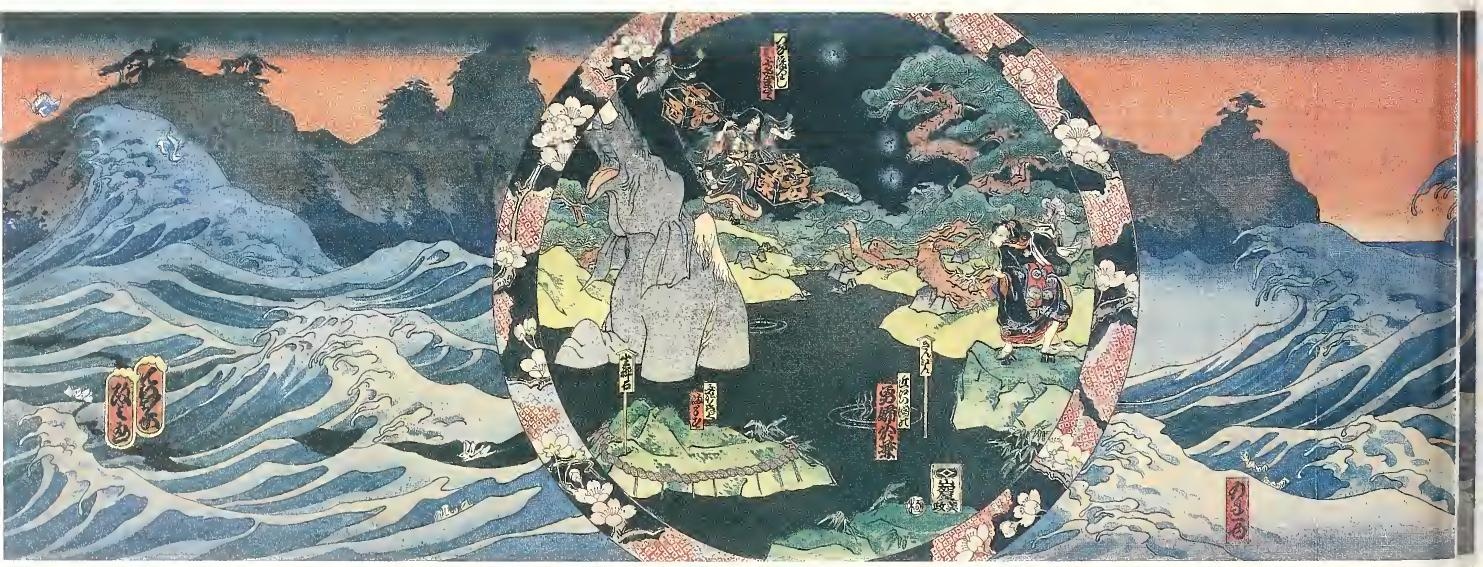


There are problems, however, with understanding Teraoka's multifaceted art within this framework alone. It is questionable just how much Teraoka has contributed to what cultural critic Homi K. Bhabha describes as the new "internationalism," wherein national cultures around the world are being produced from the perspective of "disenfranchised minorities." He writes, "The demography of the new internationalism is the history of postcolonial migration, the narratives of cultural and political diaspora, the major social displacements of peasantry and aboriginal communities, the poetics of exile, the grim prose of political and economic refugees."' But Teraoka does not regard himself as a "disenfranchised minority," nor are the racial issues he addresses necessarily politically charged. His perspective is more satirical than activist, and his jibes are aimed at "uncool" Japan rather than bigoted white America. A sign in La Brea Tar Pits Amusement Park admonishes the exploitative Japanese businessmen, "Don't pee in the tar pits"- - a typical Teraokaism.

Unlike the work of artists whose passions are informed by multiculturalism and identity politics, Teraoka's elaborate narratives about the ways in which the East and West collide in a postmodern, highly consumerist society are constructed from an essentially detached, nonpartisan vantage point. His conflicts are fantastic in order not to be specific, and they are not specific in order to be about broad human pathos.

Teraoka's background differs from that of most Asian-American artists active today. He was not raised in an environment of radical pluralism. Born in 1936 as Japanese fascism was escalating, Teraoka was relieved that America had stopped the war and rescued Japan from an imperialist disaster course. To most Japanese of Teraoka's generation, the United States provided welcome and rich respite. To see Teraoka solely in terms of contemporary American cultural studies is thus to ignore the more complex context of his modern Japanese being.

That Teraoka has recently gone beyond his signature pop ukiyo-e style with its familiar bicultural themes (his new work is drawn from Renaissance painting and deals with violence) confirms his independence from various movements that have too eagerly claimed him as theirs. Ultimately, Teraoka has never been concerned with "blending into" contemporary American art movements. Protecting the vestiges of modern Japanese humanism, with its particular love of the macabre, perverse, and ephemeral, he remains obsessed by one thing: to paint his vision of humanity's bizarre, often terrifying destiny. "I don't want my paintings to preach," he has said. "I am 
interested in that moment of confrontation with life when our psyche becomes shocked and naked - a vacuumed mind-set situation. A strong art is direct, but does not have any facade. It comes in a raw state."

\section{Drama and Destruction}

In 1986 Teraoka embarked on a series of paintings devoted to the specter of AIDS. To symbolize the plague's menacing power, he began working in a scale larger than ever before and in a dark, brooding palette. His first work in the series, American Kabuki/Oishiiwa (no. I), is a watercolor on paper mounted as a four-panel folding screen. It depicts an AIDS-stricken mother clutching her dying child. Her blackened teeth suggest that she is a married woman of the Edo period, while the swimming goggles she carries may refer to a contemporary news account of a Japanese woman who walked into the ocean off Santa Monica, California, wishing to kill herself and her two small children. The title also alludes to Oiwa, the female protagonist in the famous ghost tale and Kabuki play Yotsuya kaidan. Oiwa is murdered by her husband and returns from the grave to exact revenge, her face hideously deformed. In the convention of Kabuki posters, Teraoka announces AIDS as the subject of this "American drama" and then describes the scene in the adjacent inscription:

In the evening, clouds are very turbulent, storm-bearing. The sound of the waves is loud and black clouds are beginning to spread over the shoreline. As the evening wears on the full moon is revealed when the clouds part. Suddenly a cry is heard: "Help us! Help us!' But it is so faint that the audience is uncertain as to whether they heard a voice or if it is only the sound of the waves. ${ }^{10}$

Although Teraoka's work has always expressed his impassioned concern for current events, especially environmental disasters, AIDS changed the course of his art. Bhopal, Chernobyl, the grave pollution of the Rhine and the Alaskan shoreline, the rapid depletion of the ozone layer, and the greenhouse effect were abstract disasters compared to the systematic scourge of AIDS. 


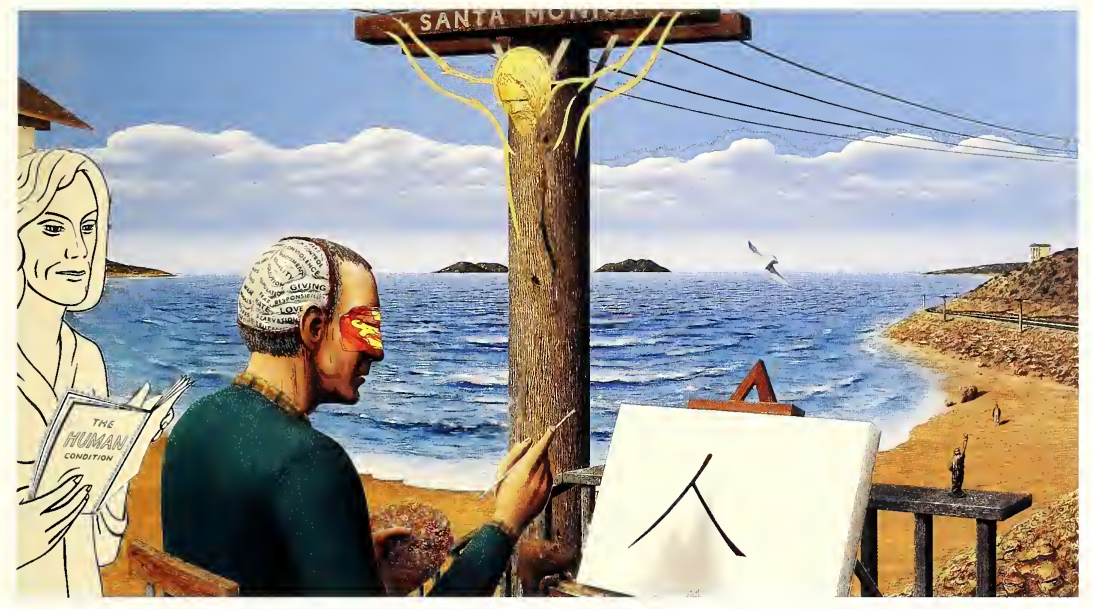

Figure 6 Llyn Foulkes, The New Renaissance, 1991. Mixed media painting, $255.3 \times 457.2$. Collection of Asher Faure, Los Angeles.
Confronting AIDS, Teraoka was challenged to go beyond the glib use of art as a tool of social protest and bitter satire to express the irate sadness of random loss. His paintings appeared, in the words of critic Dana Friis-Hansen, "soaked in the tragedy of AIDS." " As he began to relinquish the stylistic conventions of ukiyo-e, Teraoka's iconography gradually became more personal and his subject matter more emotional. He found new inspiration in grotesque Japanese ghost tales and various motifs of Kabuki theater (such as mie, the stylized gesture of concentrated emotion and drama), both of which can be filled with ominous innuendo and symbolism. Bloodsucking bats, predator frigate birds, monstrous snakes, and the trickster fox represent the new plague in a range of theatrical narratives chronicling the rituals of safe sex, the elusive cure for AIDS, and the tragedy of young death.

Extraordinary in their sheer beauty and majesty of execution and prescient in their message, Teraoka's paintings of real and fantastic figures in battles against the dread disease gained wide critical acclaim in the late 1980s, when art about AIDS was just emerging. But if representative artists of the so-called AIDS activist aesthetic - such as New York-based collectives Gran Fury and Testing the Limits - rarely produced their socially critical assaults for gallery walls, Teraoka disguised his rage behind ravishing style and comical allegory. Reviewing his "AIDS Series" show at New York University's Grey Art Gallery in 1989, New York Times critic Michael Kimmelman wrote, "Mr.Teraoka's offbeat but impassioned approach is by no means the only way to deal with this difficult subject, but it is one of the best we have had so far." 12

Allegorical narratives of "the human condition" are also the subject of recent work by 


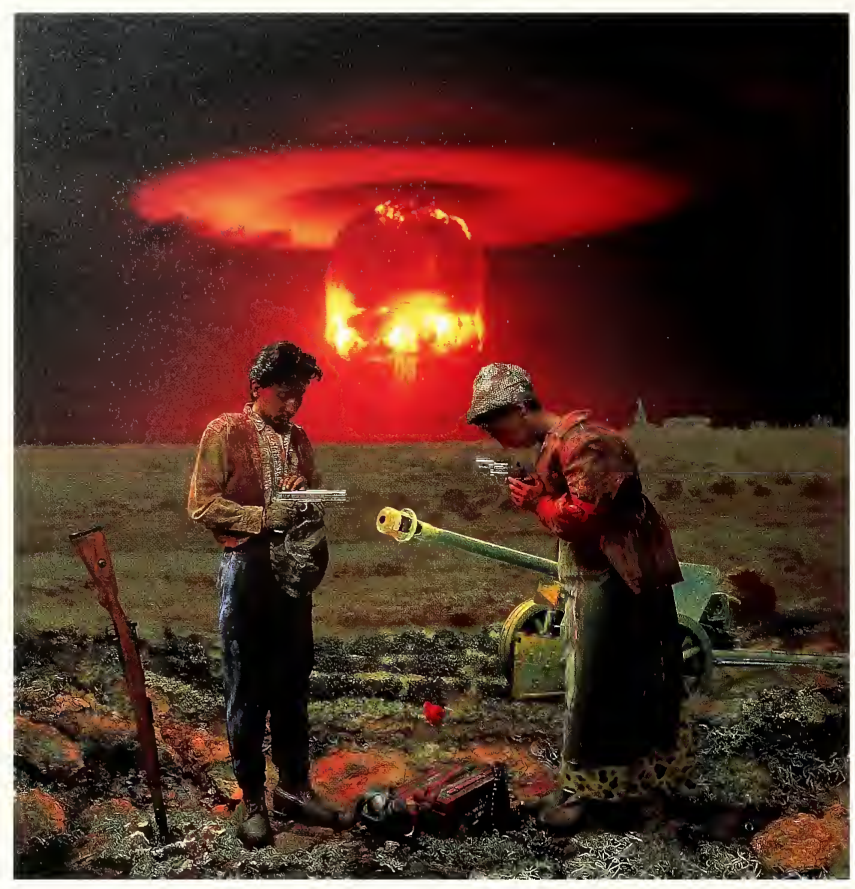

Figure 7 Morimura

Yasumasa, Brothers (A Late Autumn Prayer), 1991. Photograph and transparent medium, $276.9 \times 269.6$. Kawaguchi Museum of Contemporary Art, Saitama, Japan.

Los Angeles artist Llyn Foulkes (born 1934). The New Renaissance (fig. 6) depicts the painter at a California beach facing a canvas inscribed with the Chinese ideogram for "human." His eyes are blindfolded with scraps from a poster - a vestige of commercial or ideological propaganda - and across his exposed brain are written the urgent topics of the late twentieth century: AIDS, homelessness, starvation, pollution, gun control, and war. Foulkes shares with Teraoka the baroque futuristic qualities of Los Angeles pop, a cinematic painting style that draws from multiple image sources and focuses on front-page issues. Ultimate faith in the goodness of human nature (equality, nonviolence, and love are branded on the painter's brain as well) also informs the libertarian ideals of both West Coast artists.

In 1992 Teraoka went to Europe for an extended art tour with his partner, artist and critic Lynda Hess, a trip that was a catalyst for change. Teraoka's abiding interest in painting as allegory of human folly and psychic pain led him to Hieronymus Bosch (ca. 1450-1516) and his hallucinatory marvels of life in hell. Further, Teraoka's obsession with the extent to which contemporary media are saturated with violence - on television shows, Hollywood films, and CNN live broadcasts from the front lines of the Gulf War, Rwanda, and Bosnia - triggered his fascination with the bloody iconography of Christian saints and martyrs. Returning to Hawail, Teraoka 
embarked on a new style of painting inspired by northern European and Renaissance art. Biblical figures living present-day incarnations are the subject of his "Tree of Life" and "Adam and Eve" series. In these works, the artist casts Eve as a shaven-headed refugee in Bosnia, as a lost soul in the cyberspace era entangled in the cords of a computer mouse, and as a pregnant woman in labor beside a skeletal Adam, who is dead from a random shooting. Conceived in the vertical format of hanging scrolls but suggesting fresco tableaux, several of these paintings display patterns of what appear to be cracked, bleeding walls, as if they had been found in an old church or ancient ruins - a motif Teraoka inserts to suggest the volatile and timeless conditions of violence and war.

Departing from his earlier style, the artist uses a negative white space to define form and contour rather than the ink-black, calligraphic outline learned from his ukiyo-e training. Kimono fabric patterns are replaced with those of leather and fur, and the Kunisada features of Japanese courtesans and samurai types are replaced

Figure 8 Cindy Sherman, Untitled, 1992. Color photograph, $172.7 \times$

1 14. Courtesy Metro Pictures, New York.

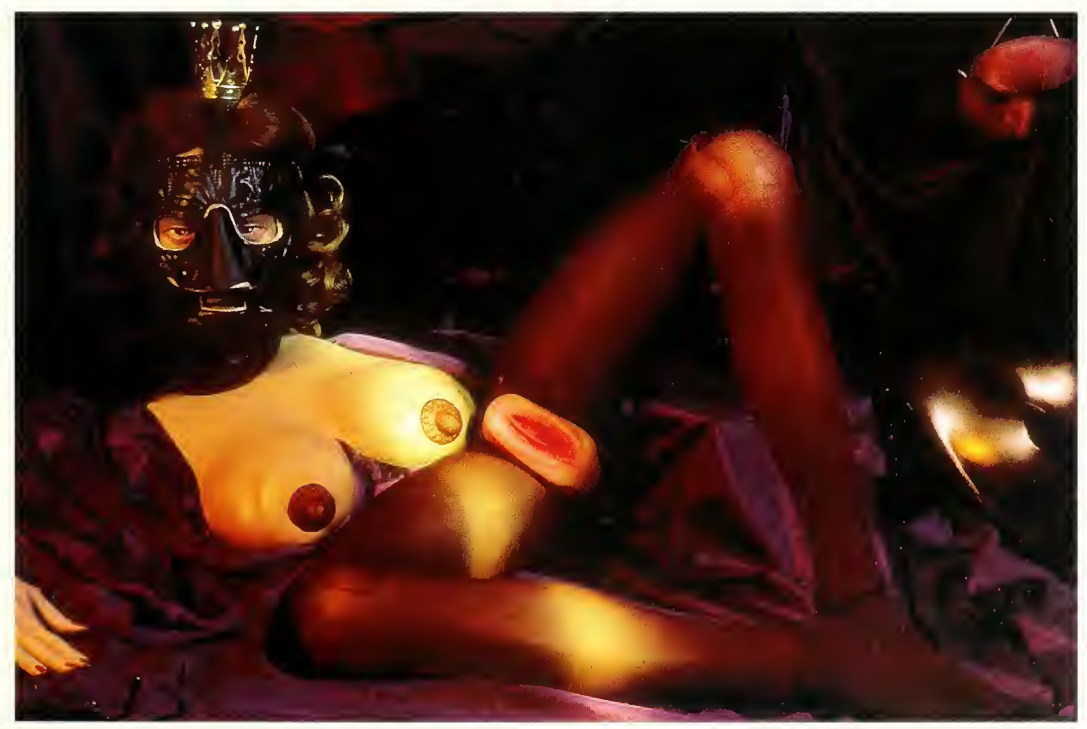


with Teraoka's deft watercolor caricatures of specific people. Finally, the artist's signature cartouches with Japanese inscriptions written in cryptic Edo-style kana script, a holdover from his pop ukiyo-e style, gradually disappear. The attachments Teraoka had to the look of Nihon-teki, or "the Japonesque," have loosened as he braves being an artist of no particular nationality engaged with the dilemmas of life at the millennium.

The conspicuous artifice of Teraoka's recent paintings and their disturbing references to classical European sources are reminiscent of work by Morimura Yasumasa (born 1951), internationally recognized as the leading figure of contemporary Japanese postmodern art. Manipulating images of European masterpiece paintings via the computer, Morimura transposes himself into the role of various iconic protagonists to produce a freakish play of inverted gender, race, and cultural epoch. Like Teraoka, he laces his bizarre juxtapositions with allusions to Armageddon, such as the mushroom cloud exploding on the horizon of Millet's pastoral Angelus (fig. 7); and, as in his hysterical rendering of Cranach's famous version of Golgotha, he aims to expose how mass media and commodification have thoroughly disrupted "traditional" notions of culture and religion.

Teraoka's ornate fictions, lewdly suggestive of drama and destruction, also recall the work of Cindy Sherman (born 1954; see fig. 8). Both Teraoka and Sherman focus on women as objects of perverse fantasy and abuse, and both use theatrical scenes to narrate the empty excesses of contemporary society. Most significantly, the central issue of their respective work is the pernicious influence of the media. Indeed, this is the theme of Teraoka's huge watercolor masterpiece, the Guernica-like Media Bacchanalia (no. 39).

By far the largest painting of Teraoka's oeuvre, Media Bacchanalia combines all the elements of his personal art-historical iconography. Cast, as is the artist's custom, in the guise of a contemporary topic (here, Bill and Hillary Clinton being devoured by rapacious press over the Whitewater affair) and executed in a mannerism rich with cultural referents both Eastern and Western, the "mural" is a postmodernist allegory of purgatory, American-style. Yet however menacing the violence - fires, blood, and human bones are repeating motifs in this ghoulish narrative - Teraoka himself survives, and we through him, by staging irony and painting well. Observing millennium's end, he mocks all but the profound power of Art to ravish. 
I. This and all subsequent quotations by the artist are taken from interviews with the author between September and December 1995.

2. Gerard Haggerty, "Making Great Waves," in Masami Teraoka (Oakland, Calif: Oakland Museum, 1983), p. 5.

3. Ushio Shinohara, Zen'ei no michi (The Road of the Avant-Garde), trans. Kazu Kaido, in Reconstructions: AvantGarde Art in Japan 1945-1970 (Oxford: Museum of Modern Art, 1985), p. 70.

4. James Jensen, interview with the author, Honolulu, September 22, 1995.

5. Richard Marshall," Preface and Acknowledgments," in Masami Teraoka (New York:Whitney Museum of American Art, 1979), n.p.

6. Ibid., n.p.

7. Elisabeth Sussman, "Coming Together in Parts: Positive Power in the Art of the Nineties," in Elisabeth Sussman et al., 1993 Biennial Exhibition (New York:Whitney Museum of American Art in association with Harry N. Abrams, Inc., 1993), p. 15.

8. Margo Machida, "Out of Asia: Negotiating Asian Identities in America," in Margo Machida, Vishakha N. Desai, and John Kuo Wei Tchen, Asia/America: Identities in Contemporary Asian American Art (New York: Asia Society Galleries and the New Press, 1994), p. 100.

9. Homi K. Bhabha," Beyond the Pale: Art in the Age of Multicultural Translation," in Sussman et al., 1993 Biennial Exhibition, p. 66.

10. Howard A. Link, Waves and Plagues: The Art of Masami Teraoka (Honolulu:The Contemporary Museum, 1988), p. 55 .

1 I. Dana Friis-Hansen, Simple Pleasures (Cambridge, Mass.: MIT-List Visual Arts Center, 1990), p. 26.

12. Michael Kimmelman, "Review/Art: An Approach to AIDS," The New York Times, February 24, 1989. 


\section{MASAMI TERAOKA with LYNDA HESS}

HOUGH I WAS BORN and raised in Japan, I feel lucky

to have lived more than half my life in America. It has been exciting and inspiring for me to experience two such disparate cultures. When I strained my wrist lifting my first American coffee cup, I realized there was more to the differences between the two cultures than I had anticipated. Subtlety is appreciated in Japan, while straightforward, bold (and large!) approaches carry more weight in America. Compassion (nasake) and obligation (giri) hold Japan and Japanese families together, while Americans value independence of mind, and people may experiment with a multitude of lifestyles and ideas. American freedom is addictive. My creativity flourished here because individualism is cherished and nurtured.

I arrived in Los Angeles at the age of twenty-five and submerged myself in the liberating spirit of the American 1960s. By the 1970s I realized it was important for me to explore my Japanese cultural roots as well. Until recently my work focused on social and cultural issues in and between my two "home" countries. I now live in Hawaii, a great place to observe both Americans and Japanese. Although Japanese tourists look Westernized, they think very differently from Americans. In my paintings, I often depict Japanese with samurai-era hairstyles to symbolize their traditional attitudes. When such people come into contact with Westerners on the beach in Hawail, they face culture shock, unsure whether to be seduced or repelled by American excesses and freedom.

My earlier paintings were inspired by ukiyo-e (literally, "pictures of the floating world") woodblock prints and by pop art. I had always been fascinated by the strong compositions of Japanese woodblock print artists Utagawa Kunisada (1786-1865) and Katsushika Hokusai (I759-1849). I learned figure drawing from Kunisada and wave drawing from Hokusai. On the 
American side, the works of pop artists Claes Oldenburg (born 1929) and Tom Wesselmann (born 1931) inspired me, especially Oldenburg, whose ideas are outrageous and, I thought then, the most appropriate example of what American art is supposed to be. The American artists' boldness was loud but dynamic. Reflecting a consumer orientation, pop art seems to me the ideal product of American culture. America is an extremely consumer-oriented society, and in recent years the Japanese have also adopted this attitude. At Hanauma Bay, Hawail, civilized consumer tribes of both nationalities haul recreational devices to the beach: cameras, snorkels, fins, scuba diving equipment, radios, ice chests - everything you can imagine. Why don't they just take the whole house? Sometimes they seem to leave it all on the beach. I find plastic bags, cigarette butts, and Styrofoam cups scattered in the sand every day. Massive pollution is the obvious result of mass consumerism.

After I worked with themes such as intercultural relations, consumerism, and environmental degradation, the issues surrounding AIDS (acquired immunodeficiency syndrome) seemed a natural progression. Expanding my subject matter compelled me to synthesize a variety of aesthetic traditions in an effort to create an effective visual language. In retrospect, I believe this stylistic and conceptual evolution began with my AIDS paintings in 1986.

The AIDS theme encompasses many serious issues. First, it decimates the comfort of love, awarding the lover with a death sentence, an unthinkable trap! In the early eighties attention was focused on the spread of AIDS in the gay community, which raised gender and sexual issues. Proponents of increased AIDS awareness and funding used the media to advance their message. Safe sex and the open promotion of condoms and/or abstinence were framed as health or morality issues. AIDS quickly became a global concern, highlighting how interconnected the world has become. Whether technology could stem the plague became a crucial question. Science today is advanced enough to send satellites and shuttles into space, but still struggles with microscopic viruses that torment our earthbound race.

AIDS affects so many facets of the human condition that I was compelled to address the subject in depth. Tackling such a range of issues challenged me as an artist. I did my first AIDSthemed painting, American Kabuki/Oishiiwa (no. I), in 1986. Almost immediately the subject demanded modifications in my style and scale of work. 
For AIDS themes, the ukiyo-e technique of depicting one scene or moment from a play was useful in presenting both individual ideas and a broader, more resonant whole. Ukiyo-e often employs humorous juxtapositions, and I believe humor can be a relief when presenting a dread subject. Humorous works such as AIDSSeries / Geisha in Bath, 1988 (no. 2), and New Waves Series/Sarah and Dream Octopus, 1992 (no. 15), echoed erotic ukiyo-e subjects, and I painted them in woodblock print style.

However, as I became concerned with more complex problems such as AIDS, random violence, war, and the loss of privacy, which define the darker side of modern life, ukiyo-e became less relevant as an aesthetic, and my style had to evolve. I felt the serene, subtle colors of ukiyo-e generally inappropriate for conveying the intensity of emotion surrounding the pandemic. I needed to illuminate tension with a more textural and expressive surface than I had previously explored (see "On Technique," page 54). In addition, I found myself doing large-scale paintings in an effort to express the overwhelming nature of AIDS.These complexities required a dynamic approach and fresh imagery.

In AIDS Series/Picnic at Iris Pond, 1990, the protagonist has just received a blood report confirming that he has AIDS, while his deceased girlfriend hovers as a ghost. A picture like this draws on darker elements of ukiyo-e, the ghost story depictions, in which a blue tint on a face indicates that a person is dying or a ghost. Whether or not people know this symbolism, a blue cast on a face still imparts an otherworldly feeling. A ghost often represents someone who died young or unwillingly. AIDS Series / Geisha and AIDS Nightmare, 1990 (no. 3), shows a young woman who unexpectedly

I was born in Onomichi, a town with a hundred old temples on the Inland Sea of Japan, in 1936. As a child I spent much of my time in the surrounding mountains doing sketches, drawings, and paintings. One day I told my parents that I did not want to go to kindergarten anymore because my teacher did not give me time to draw. My mother talked to the teacher the next day. When I was seven years old, my parents encouraged me to take private watercolor lessons from a local artist. In 1959 I graduated from Kwansei Gakuin University with a bachelor's degree in aesthetics. I came to the United States in 1961 and earned an M.F.A. degree in painting at the Otis Art Institute, Los Angeles, in 1968. I have lived in Hawaii since the 1980s. 
contracted the AIDS virus. Even after death, she haunts the world, trying to complete her life. She reminisces by counting the falling petals of cherry blossoms. Ghosts haunt my AIDS series as vestiges of envy, longing, revenge, and death.

In Tree of Life Series/Eve with Eggplants, 1993 (no. 31), few remnants of the floating world can be discerned. Adam is dead, crushed beneath the foliage. Eve carries eggplants both for sustenance and as sexual/safe-sex symbols (Japanese eggplants are very phallic and as such make perfect models for demonstrating condom use), reminding us that AIDS may forever shadow our lives. This portrayal owes more to Western imagery than Japanese, in particular to Christian icons of saints and martyrs.

Humanity embodies many positive attributes but is also tied to suffering. Bloody imagery both attracts and repels. Graphic television news stories and violent movies are the norm in contemporary U.S. culture, bringing atrocities of crime and war from all over the world into our homes. Many of us have personal experiences with violence. In Los Angeles in 1994 I witnessed two drive-by shootings. In direct response to these incidents, I did Adam and Eve/Eve's Delivery, 1995 (no. 38), in which a skeleton Adam is killed - a second time-by random gunfire as he helps a very pregnant Eve to the delivery room. I have depicted random shooting as an abstract element to contrast with my figurative drawing in much the same way I formerly used boxes of text. Visually, this started with red clay-colored cracks that I first used to mimic aged religious icons. The "cracks" evolved into splotches of blood, as in Media Bacchanalia, 1995 (no. 39). These "bullet wounds" and splatters break the picture plane in the same random way - any way, anywhere - that violence happens, highlighting the risks of our contemporary society.

Dutch artist Hieronymus Bosch (ca. |450-1516) worked at a time when plague and pestilence were devastating society, and the church was the dominant moral and social force. His images went beyond straightforward observation and religious belief. He created elaborate and fantastical scenes that mixed daily life, religious mores, and parables with a visionary intensity, much like the ukiyo-e artists I admire. Bosch's paintings carry forceful, timeless, and universal messages and show a human nature and experience not very different from ours today. Perhaps the only things that are new in our world are the accessories - personal computers, computer mouses, e-mail, and the Internet. 
On Technique In my early paintings I used watercolor on paper to mimic woodblock prints. But the magnitude of the AIDS epidemic seemed to demand large-scale paintings.I had to move away from paper and create a way to adapt canvas for watercolor. Developing a method of preparing raw canvas for the application of watercolor was not easy. Sizing such a big piece of fabric was the essential challenge. If I put the canvas on the floor, it became slippery with wet glue sizing.At the very moment I thought that rolling the sizing onto the canvas with the long-handled paint roller was sort of like skiing, I slid and fell on my bum. The roller stick flew vertically while my body slid horizontally. I was covered with wet glue; its organic smell and gooey tactility were almost sensual.

I then experimented with another method I called sailing-style sizing. This one develops arm and stomach muscles as well as coordination. The canvas is hung from the wall and stapled, top and bottom, to poles. It should look like the sail of a Chinese junk. The whole canvas is then dipped into a long sizing-filled trough. While you raise the wet canvas from the trough with one arm, you scrub it with your other arm using a coarse brush, so that the sizing saturates the fiber.When it is completely dry, you repeat the process. Each canvas needs about a dozen dip-scrubbings during preparation. By the time you finish, you will be physically fit and won't need to buy elaborate exercise machines. This sailing method is not as much fun as the ski style, but it is more effective for the canvas and safer for the artist, if less erotic.

Painting on these large canvases required a different approach from painting on paper. The canvas did not easily take detailed work. The fabric's roughly woven texture called for bolder, looser strokes and provided less leeway for mistakes. Ukiyo-e prints always measured about thirty-eight by twenty-five centimeters because of the technicalities of printing from a block of wood. By way of contrast, the smallest of my canvas pieces was about three by two meters. Painting the huge brushstrokes necessary for this scale became an aerobic dance for me. I used ink and watercolor to create my own free-form style. The lines I drew on canvas were softer on the edges and more expressive in texture than a woodblock print line could ever have been. In retrospect, I realize that experimenting with this scale changed the general stylistic direction of my painting. 
The speed of today's high-tech revolution and the global invasion by the AIDS virus are not equaled by the speed of human evolution. Our knowledge and understanding have not developed fast enough to address these new challenges. Our spiritual and philosophical development seems to have reached its limit, but eternal human dilemmas continue. The panorama of life from the bright to the dark sides is vast. It is important to have an overall view.

I am concerned with the relationship between aesthetics and real life experiences. Each painting is a diary page, documenting my thoughts about the time and society in which I live. Expressing my being is crucial to creating art. Often I am drawn to subjects that are difficult and provocative because they make life compelling.

Although I depict challenging subjects, I feel that the supporting actors of humor, satire, sensuality, and strong aesthetics are always at my service. I construct my image by putting these elements together in a cohesive way. Mere depiction of social and cultural issues is not enough. My work has to create something that goes beyond simple perception. To make a strong statement, art needs timeless aesthetic qualities. These can take any subject matter to a higher level of experience. That is the essence of what I am pursuing. Happiness, pain, sorrow, and death mark our experience as human beings. The contradictory elements of life are gifts that drive my every brushstroke. The changing nature of our world motivates me to creatively monitor our times. 
BORN

1936 Onomichi, Japan

\section{EDUCATION}

1959 Kwansei Gakuin University, B.A. in Aesthetics, Kobe, Japan

1968 Otis Art Institute, B.A., M.F.A., Los Angeles

\section{SELECTED SOLO SHOWS}

1973 David Stuart Gallery, Los Angeles

1975 Space, Los Angeles (1977, '79, '80, '82, '85, and '86)

1977 Santa Barbara Museum of Art, Santa Barbara, CA

1979 Whitney Museum of American Art, New York

1980 Newport Harbor Art Museum, Newport Beach, CA

Honolulu Academy of Arts, Honolulu

1983 Oakland Museum, Oakland, CA

1985 Santa Barbara Contemporary Arts Forum, Santa Barbara, CA

1988 The Contemporary Museum, Honolulu

1989 Grey Art Gallery, New York University, New York lannetti/Lanzone Gallery, San Francisco

Victorian College of the Arts, Melbourne, Australia

1990 Henry Art Gallery, University of Washington, Seattle Pamela Auchincloss Gallery, New York Montgomery Museum of Fine Arts, Montgomery, AL

1991 Schmidt/Dean Gallery, Philadelphia Indianapolis Museum of Art, Indianapolis

1992 Pamela Auchindoss Gallery, New York Macquarie Galleries, Sydney, Australia Rebecca Hossack Gallery, London

1994 Pamela Auchincloss Gallery, New York 
1995 Hui No'eau Visual Arts Center, Maui, HI

University of Colorado at Boulder

Pamela Auchincloss Gallery, New York

1996 Arthur M. Sackler Gallery, Smithsonian Institution, Washington, DC McKinney Art Center, Dallas

\section{SELECTED GROUP EXHIBITIONS}

1974 Baxter Art Gallery, California Institute of Technology, Pasadena, CA

1975 Newport Harbor Art Museum, Newport Beach, CA Los Angeles Municipal Art Gallery, Los Angeles Los Angeles Institute of Contemporary Art, Los Angeles

1976 Museum of Modern Art, New York Los Angeles County Museum of Art, Los Angeles

1978 Whitney Museum of American Art, New York Frederick S. White Art Gallery, UCLA, Los Angeles

1980 Albuquerque Museum of Art, History and Science, Albuquerque, NM

1983 Corcoran Gallery of Art, Washington, DC American Academy and Institute of Arts and Letters, New York

1984 Museo Rufino Tamayo, Mexico City

1986 Walker Art Center, Minneapolis Willard Gallery, New York

National Gallery of New South Wales, Sydney, Australia Amerika Haus/United States Cultural Center, Berlin

1987 Los Angeles County Museum of Art, Los Angeles Taipei Fine Arts Museum, Taiwan

1989 Washington State University Museum of Art, Pullman, WA

1990 MIT-List Visual Arts Center, Cambridge, MA Fukuoka Prefecture Museum of Art, Fukuoka, Japan

199I National Museum of American Art, Smithsonian Institution, Washington, DC

1992 Whitney Museum of American Art, New York American Center, Paris, France Grey Art Gallery, New York University, New York

1993 Sonia Henie-Niels Onstad Foundation, Hovikodden, Norway Museum in Schloss, Bad Pyrmont, Germany International Center for Graphic Art, Tiboli, Ljubljana, Slovenia

1994 Spiral/Wacoal Art Center,Tokyo Australian National Gallery, Canberra, Australia Asia Society Galleries, New York Guggenheim Museum, SoHo, New York 
1995 Long Beach Museum of Art, Long Beach, CA Walker Art Center, Minneapolis San Francisco Museum of Modern Art, San Francisco Center for the Arts at Yerba Buena Gardens, San Francisco

1996 Contemporary Art Center, Escondido, CA Los Angeles County Museum of Art, Los Angeles University of Hawaii Art Gallery, Honolulu Walsall Museum and Art Gallery, Walsall, U.K.

\section{ARTIST IN RESIDENCE}

1989 School of Art, Victorian College of the Arts, Melbourne, Australia

\section{SELECTED LECTURES}

1979 Whitney Museum of American Art, New York

1987 Los Angeles County Museum of Art, Los Angeles

1989 Oakland Museum, Oakland, CA Victorian College of the Arts, Melbourne, Australia School of Visual Arts, New York

I 992 Henry Art Gallery, University of Washington, Seattle Institute of Fine Arts, New York University, New York New Canberra School of Art, Canberra, Australia

1994 Asian Art Society (panel discussion), New York

1995 University of Colorado at Boulder San Francisco Art Institute, San Francisco

\section{SELECTED PUBLIC COLLECTIONS}

Achenbach Foundation for Graphic Arts/Fine Arts Museums of San Francisco, San Francisco Albuquerque Museum, Albuquerque The Contemporary Museum, Honolulu Frederick R. Weisman Foundation of Art, Los Angeles Hawaii State Foundation on Culture and the Arts, Honolulu Honolulu Academy of Arts, Honolulu Jacksonville Art Museum, Jacksonville, FL Long Beach Museum of Art, Long Beach, CA Los Angeles County Museum of Art, Los Angeles Metropolitan Museum of Art, New York McKinney Art Center, Dallas 


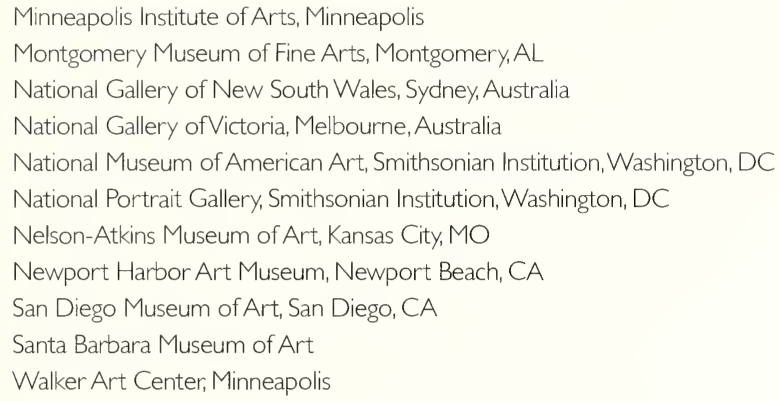




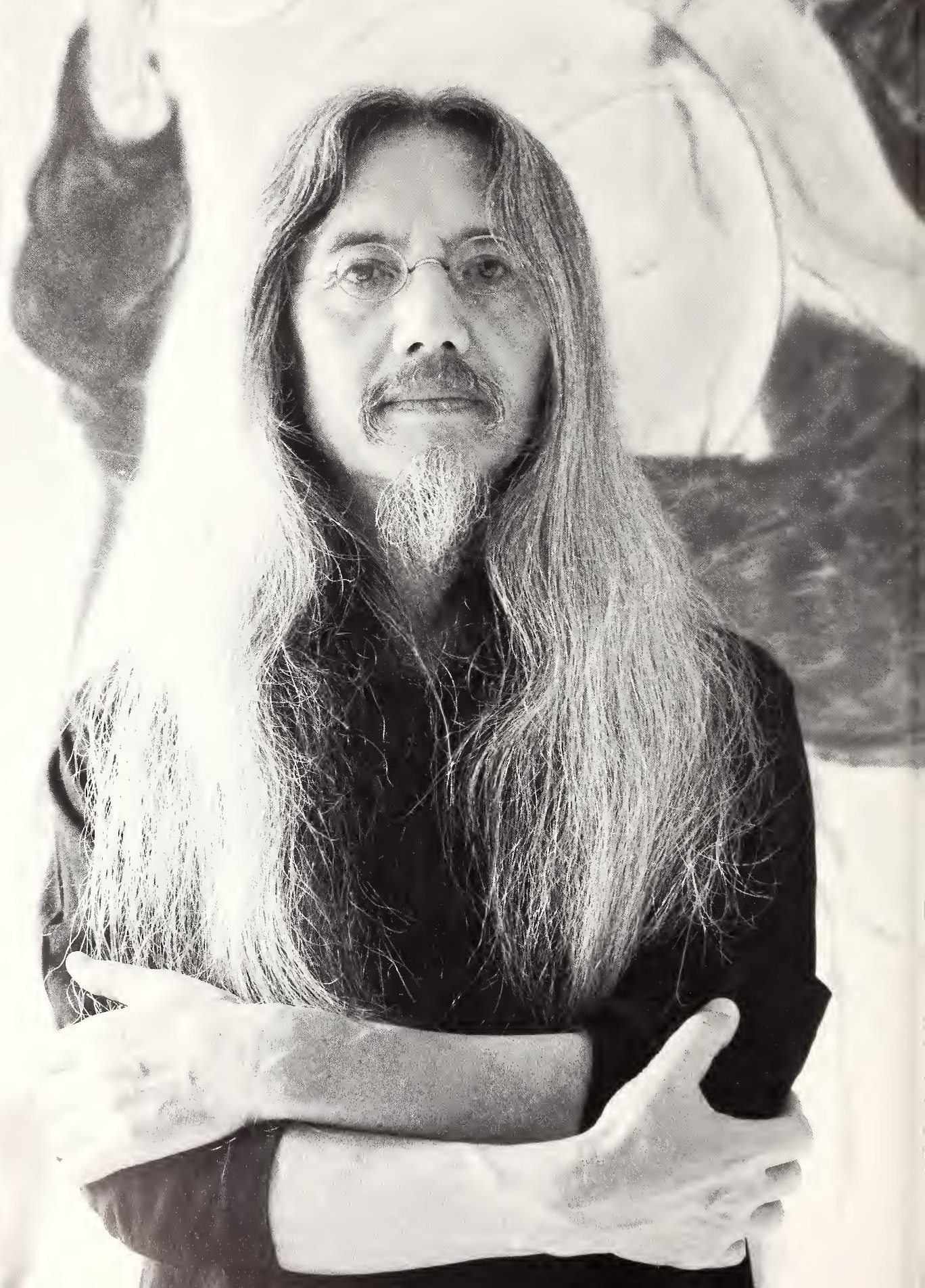




\section{PORTFOLIO}

Comments by Masami Teraoka

Masami Teraoka, 1995. 


\section{American Kabuki/Oishiiwa}

1986

Watercolor on paper, mounted as a four-panel screen

$196.9 \times 393.7$

Courtesy of the artist

In the early eighties I couldn't begin to grasp the devastation that AIDS could cause. I didn't even know how the disease was transmitted. In 1986 I discovered that a friend's baby had contracted AIDS through a blood transfusion. I had to take a deep breath to confront my friend's painful isolation. For the first time I understood that AIDS was not someone else's problem. That experience led to my first AIDS theme painting, American Kabuki/Oishiiwa. Kabuki is a traditional form of
Japanese play that originated among the merchant class in the Edo period (1615-1868).

For Oishiiwa I combined two Japanese words. Oishii means "delicious," and Oiwa is a scary female ghost who had a bruised, swollen eye. The image flows from the mother and child's isolation from friends and family. The mother's swim goggles hang at her wrist to symbolize her connection to a happier life. (See page 44.)

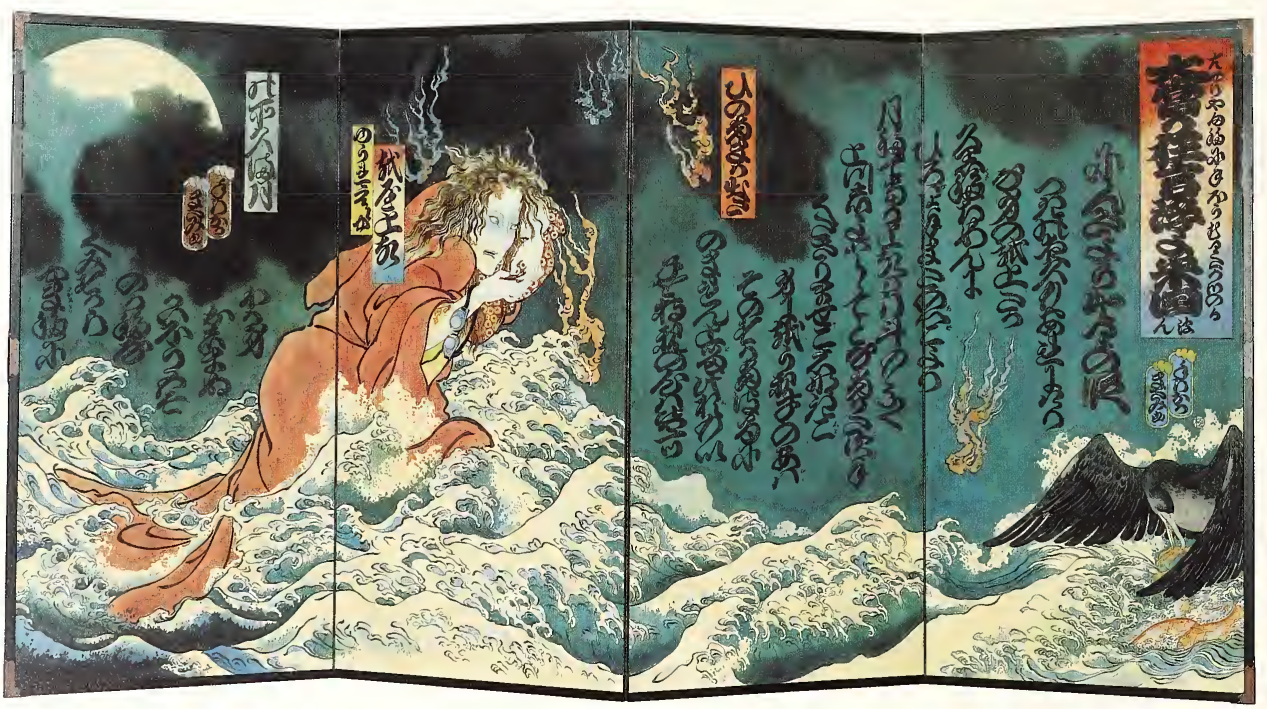


2 AIDS Series/Geisha in Bath

1988

Watercolor on unstretched canvas

$274.3 \times 205.7$

Artist's collection

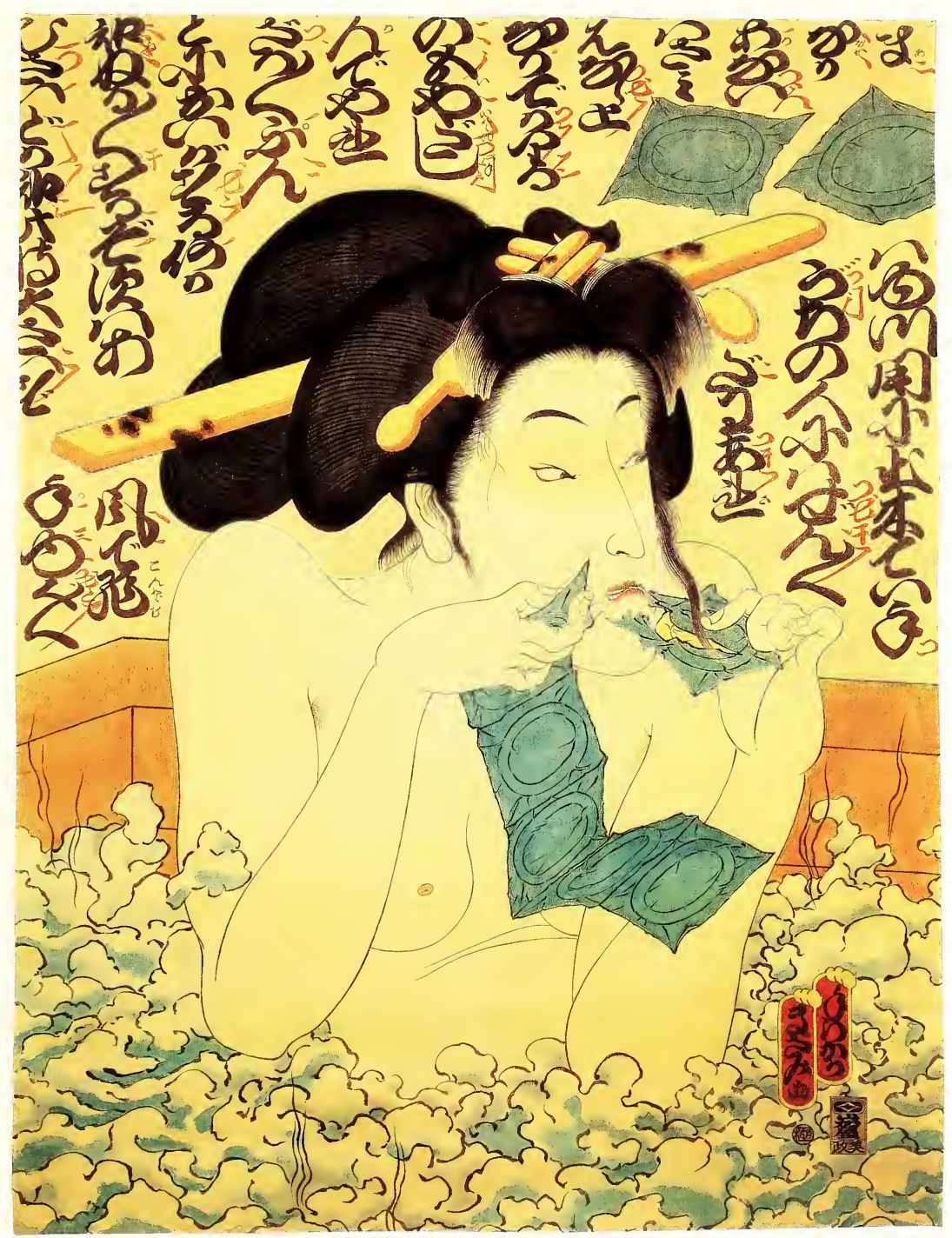




\section{AIDS Series/Geisha and AIDS Nightmare}

1990

Watercolor on unstretched canvas

$269.9 \times 188$

Courtesy of the artist

In 1989 I was a visiting artist at the Victorian College of the Arts in Melbourne, Australia. During a slide lecture, I spoke about AIDS. Someone asked me a question about eyes, and I was confused. Soon I realized the students were talking about AIDS with an accent. At that time Australians, even doctors and nurses, didn't seem to worry about contracting AIDS. When I asked what kind of protection surgeons and nurses used, they showed me paper hats and shoe covers.

The geisha in this work represents an oldstyle Japanese woman, not necessarily a traditional geisha. She followed the condom instructions carefully, but still contracted AIDS. The falling cherry blossom petals represent the beautiful memories of her life. 


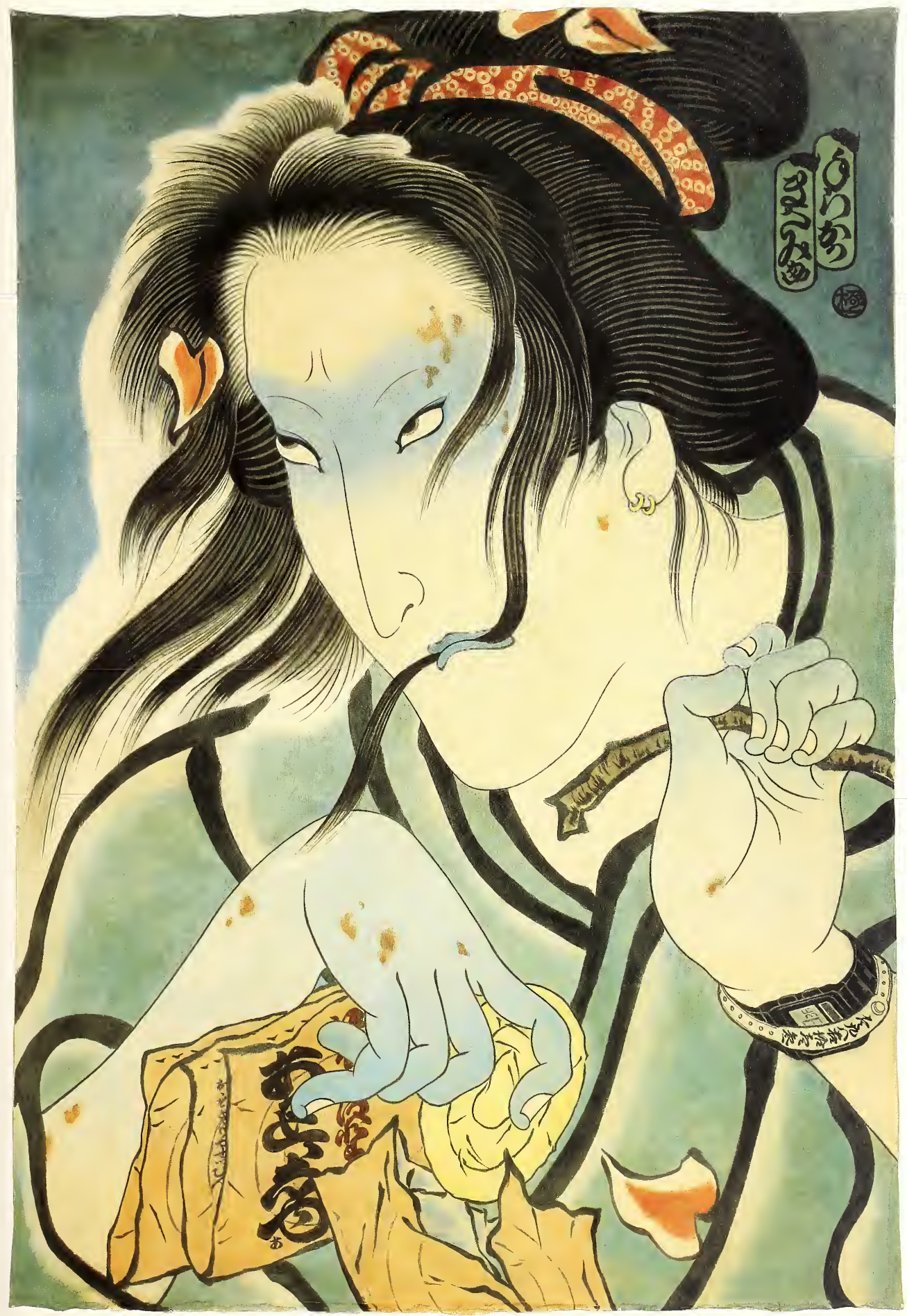




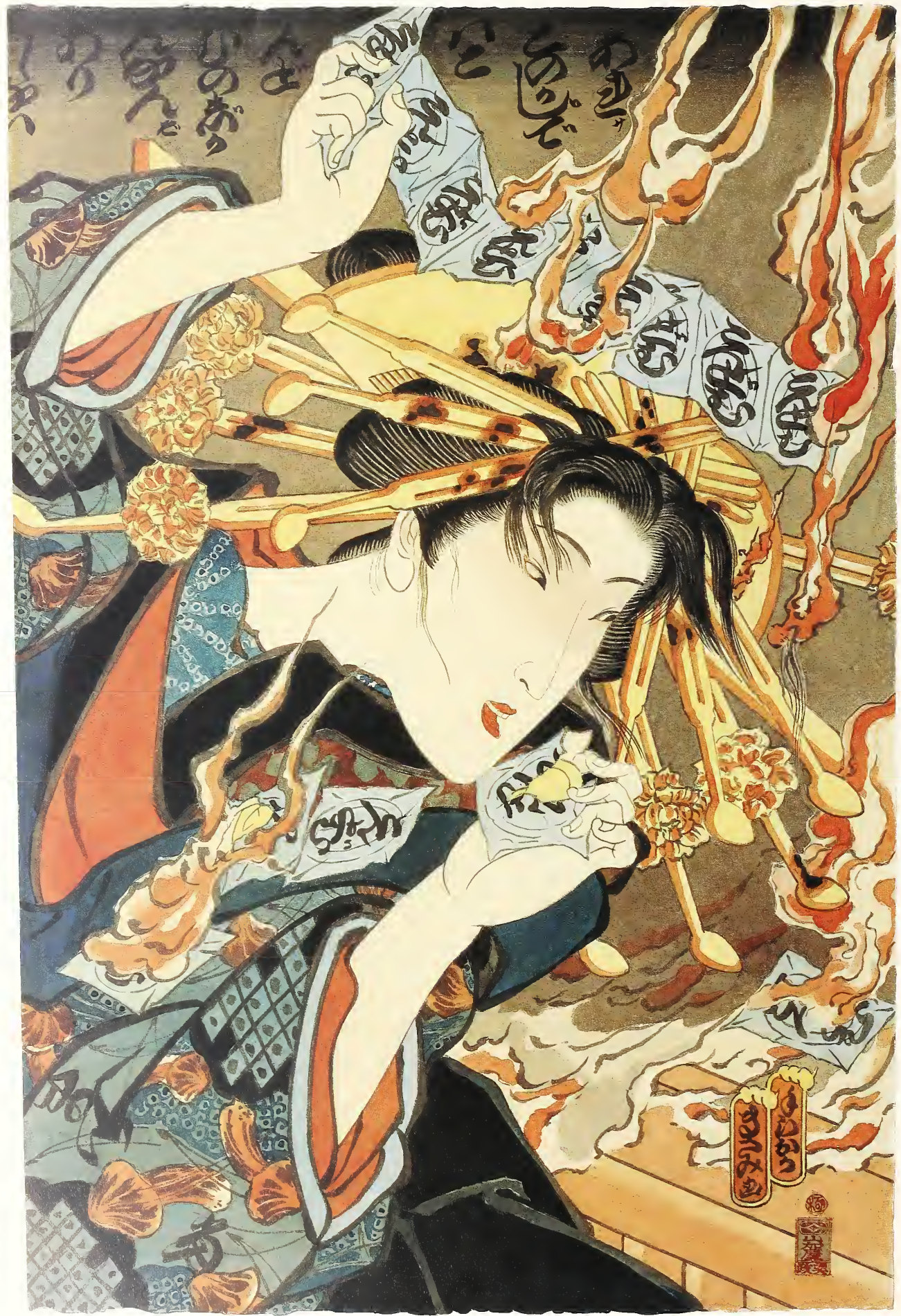


44 AIDS Series/Oiran and L.A. Fire

1988

Watercolor on paper $56.5 \times 38.1$

Courtesy of the artist.
5 AIDS Series/Samurai Twist

1988

Watercolor on paper

$56.5 \times 38$

Courtesy of the artist

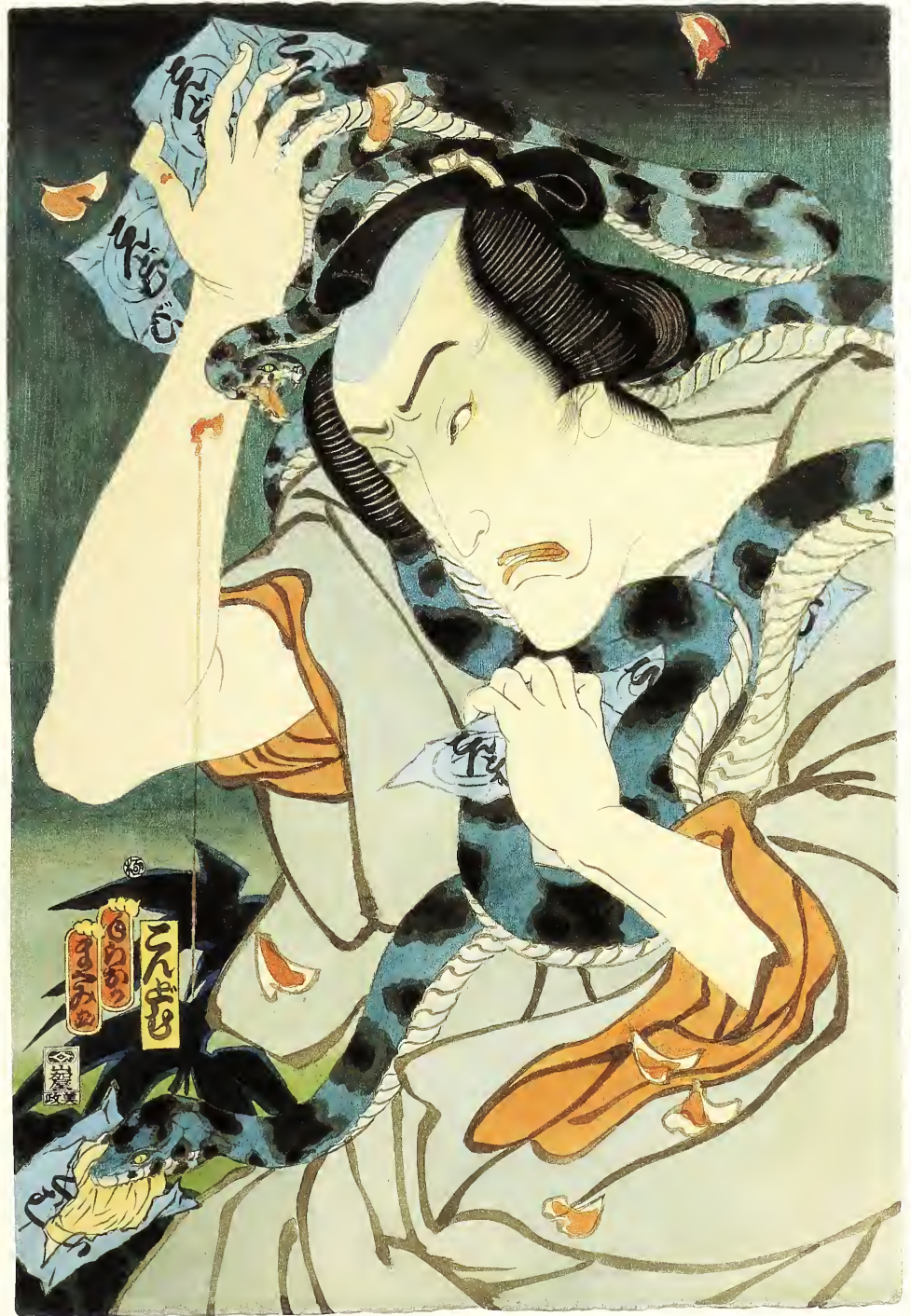


6 AIDS Series/Tattooed Woman and Flying Saucers

1988

Watercolor on paper

$74.3 \times 104.8$

Courtesy of the artist

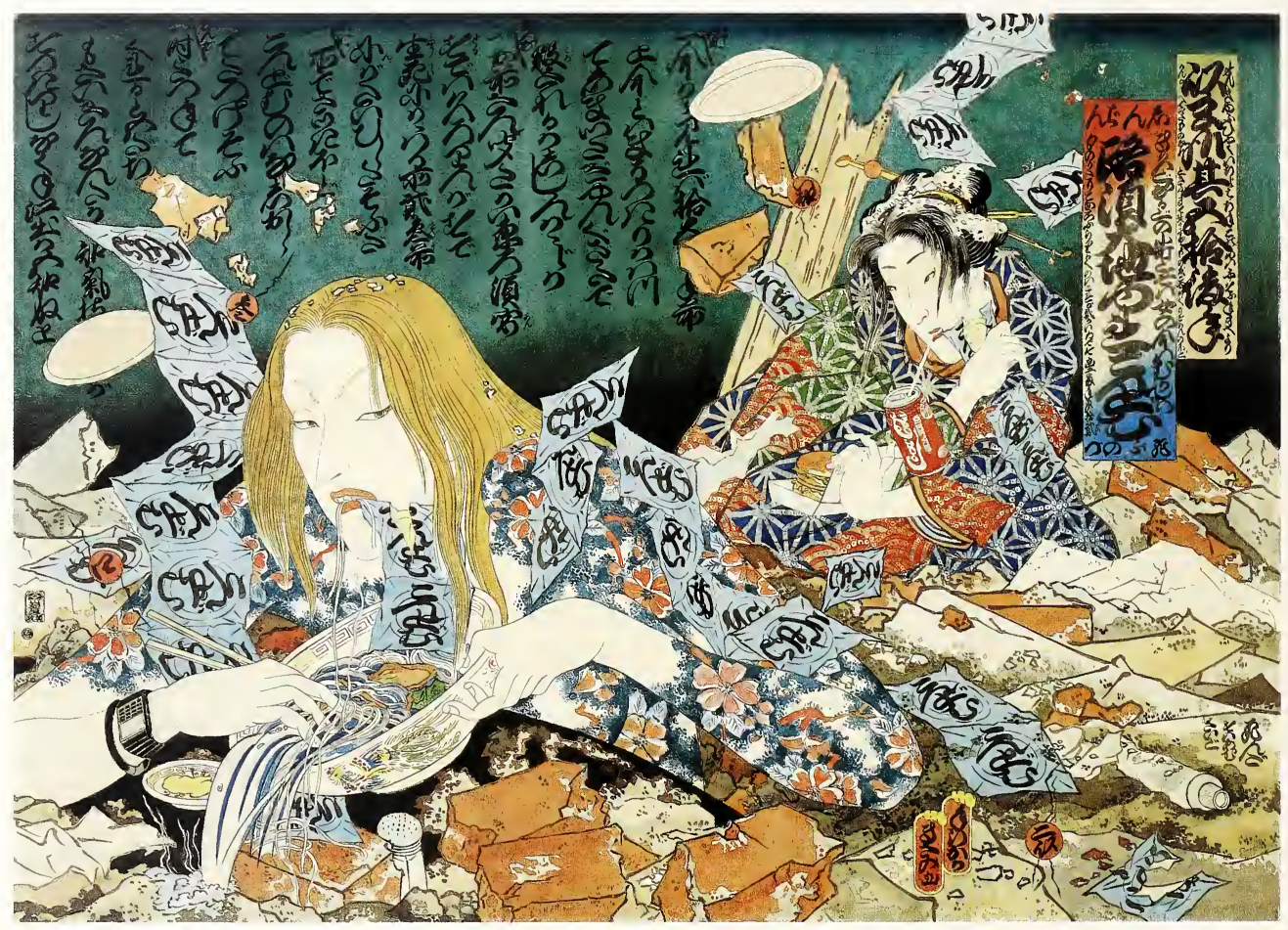


7 AIDS Series/Harajuku Boy

1988

Watercolor on paper

$56.5 \times 38.1$

Courtesy of the artist
Harajuku is a popular district in Tokyo where

young people gather on weekends to sing and dance to American music. Dressed like Elvis and other rock stars, the bands try to attract a crowd by singing in English. In my painting a Harajuku boy struggles with his fear of AIDS, wondering when the virus might attack. He reminisces about the bright, fun days in Harajuku.

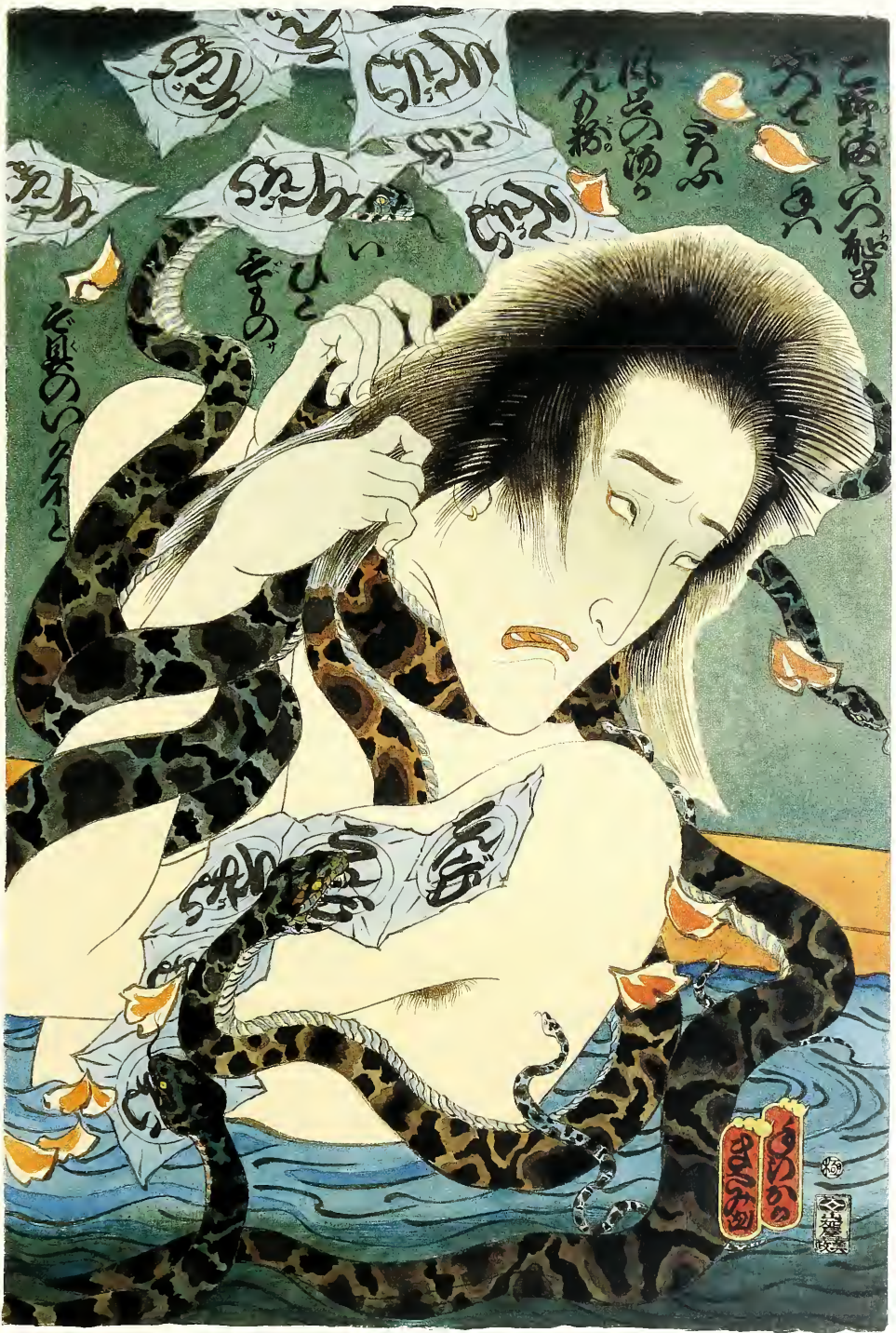


8 AIDS Series/Punk Woman

1988

Watercolor on paper

$56.5 \times 38.1$

Courtesy of the artist

\section{AIDS Series/Oiran and Kite}

1988

Watercolor on paper

$56.5 \times 38.1$

Courtesy of the artist

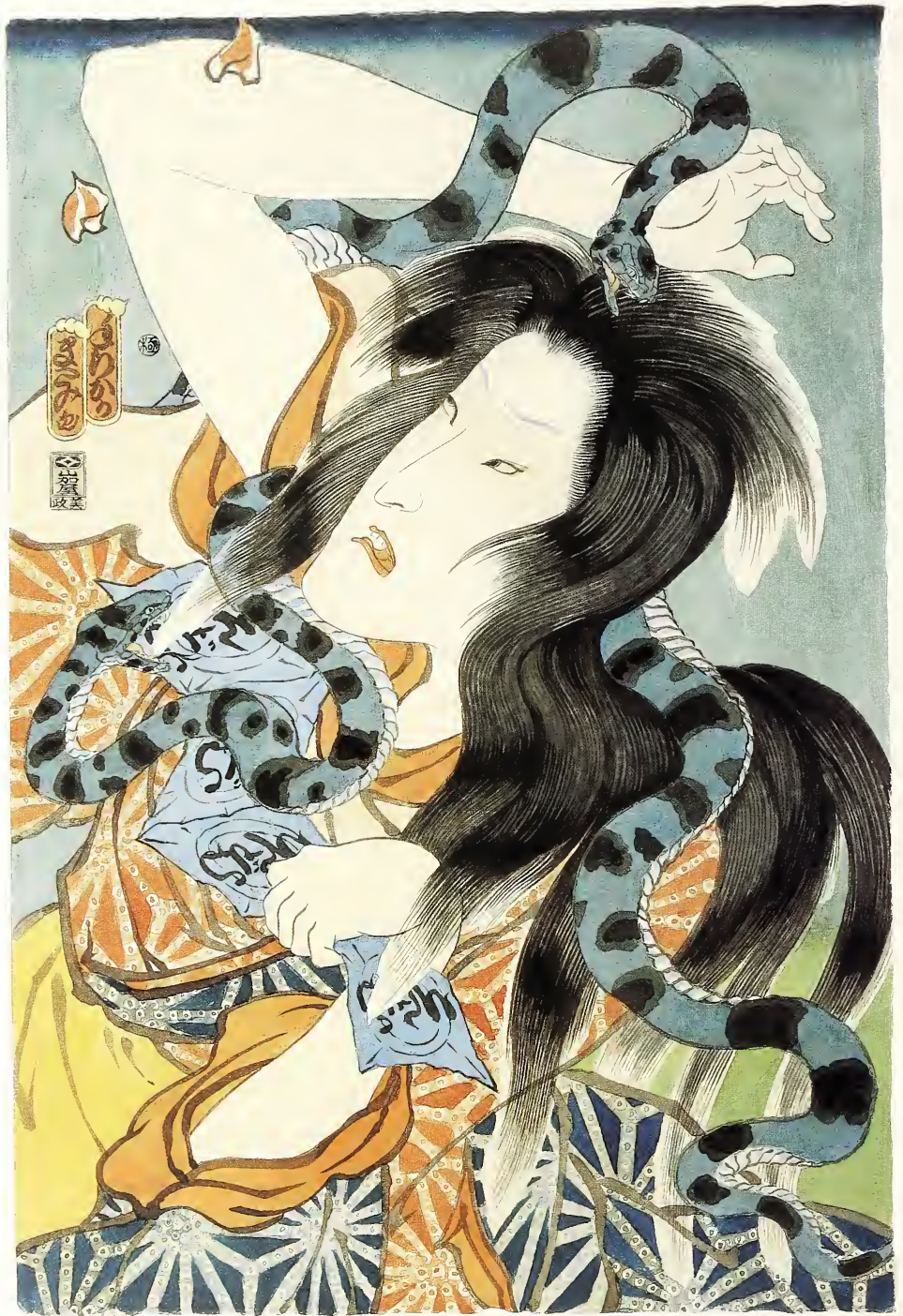




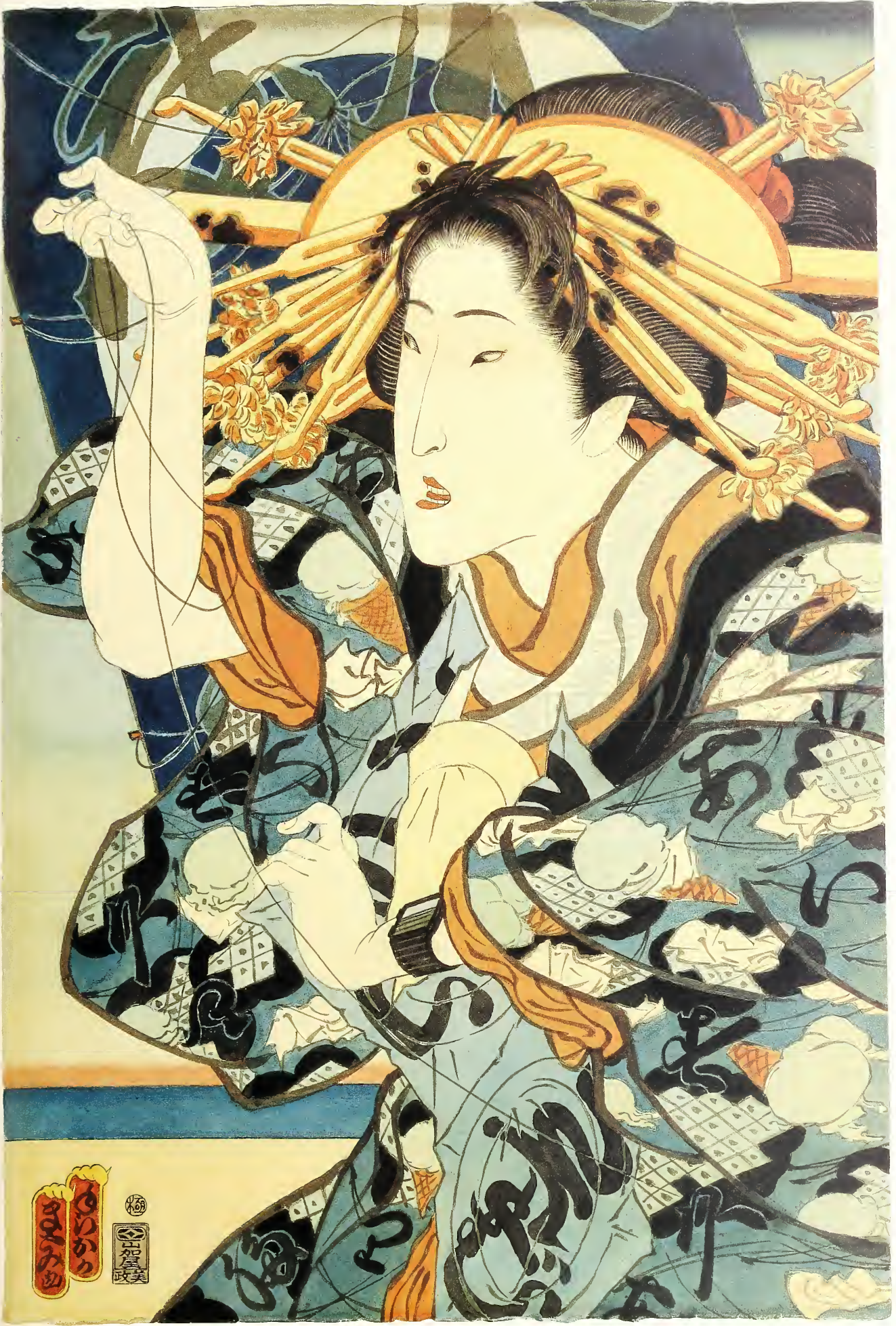


1990

Watercolor study on paper

$75.4 \times 111.3$

Courtesy of the artist

Hanging Rock is an outcropping of oddly shaped giant rocks near Melbourne, Australia. Climbing up is easy if you stick to the path. Coming down seems easy, too, but there's an overwhelming temptation to try to make your own way. That is a mistake. Halfway down on a slope, I almost got wedged permanently between two massive stones. I knew that retreat (back up) was impossible and hoped gravity would be gentle with me. In a famous movie about Hanging Rock, young girls mysteriously vanish between the rocks, and when climbing, you do feel that you'll disappear and never be heard from again.

I thought Hanging Rock would be a good setting for a piece about Robert Mapplethorpe (1946-1989), whose photography has been so controversial for government officials. They would like to make him disappear. In my painting Mapplethorpe's ghost assistant helps him dry photographs.

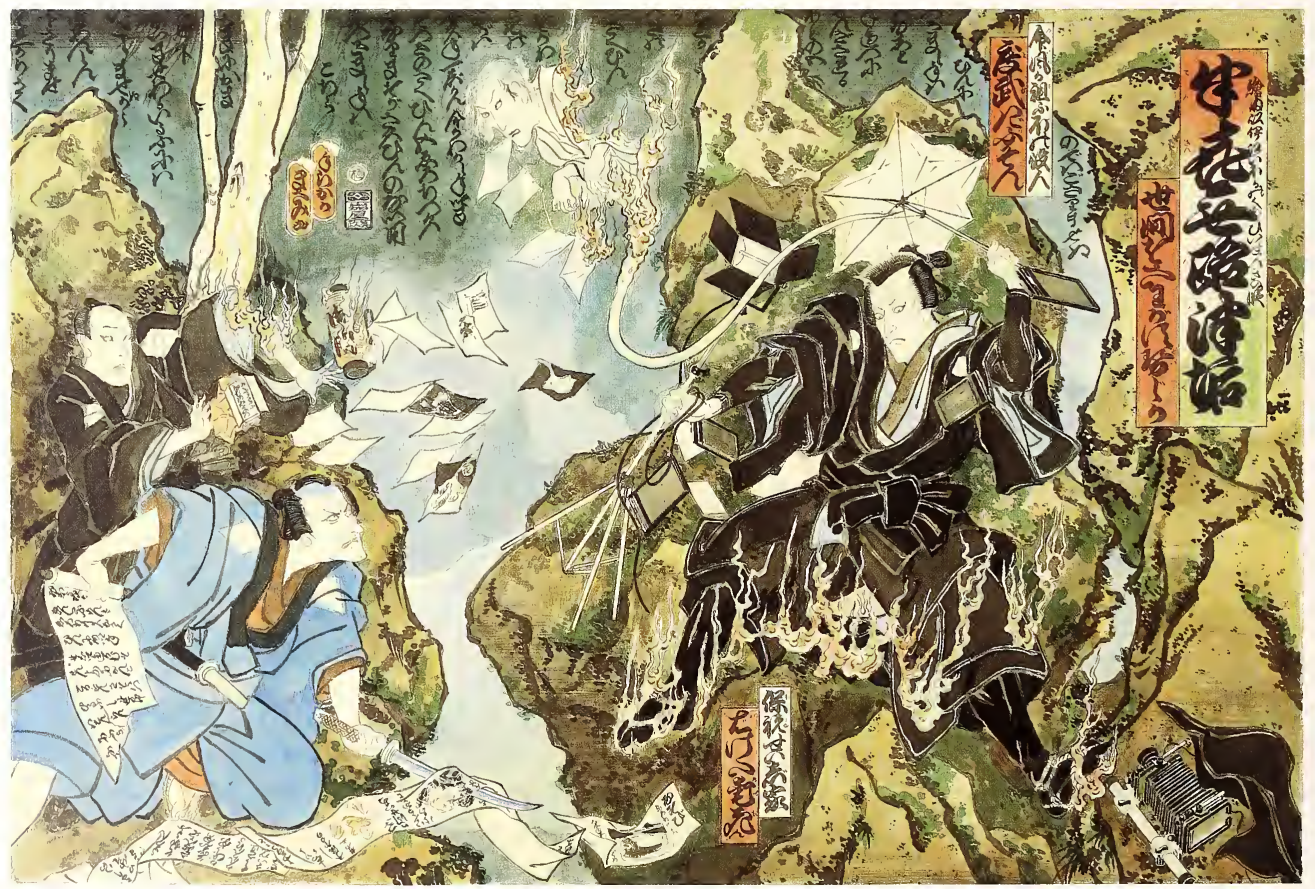




\section{AIDS Series/Surgeon and Space Mask}

\section{0}

Watercolor on unstretched canvas

$276.9 \times 189.2$

Courtesy of the artist

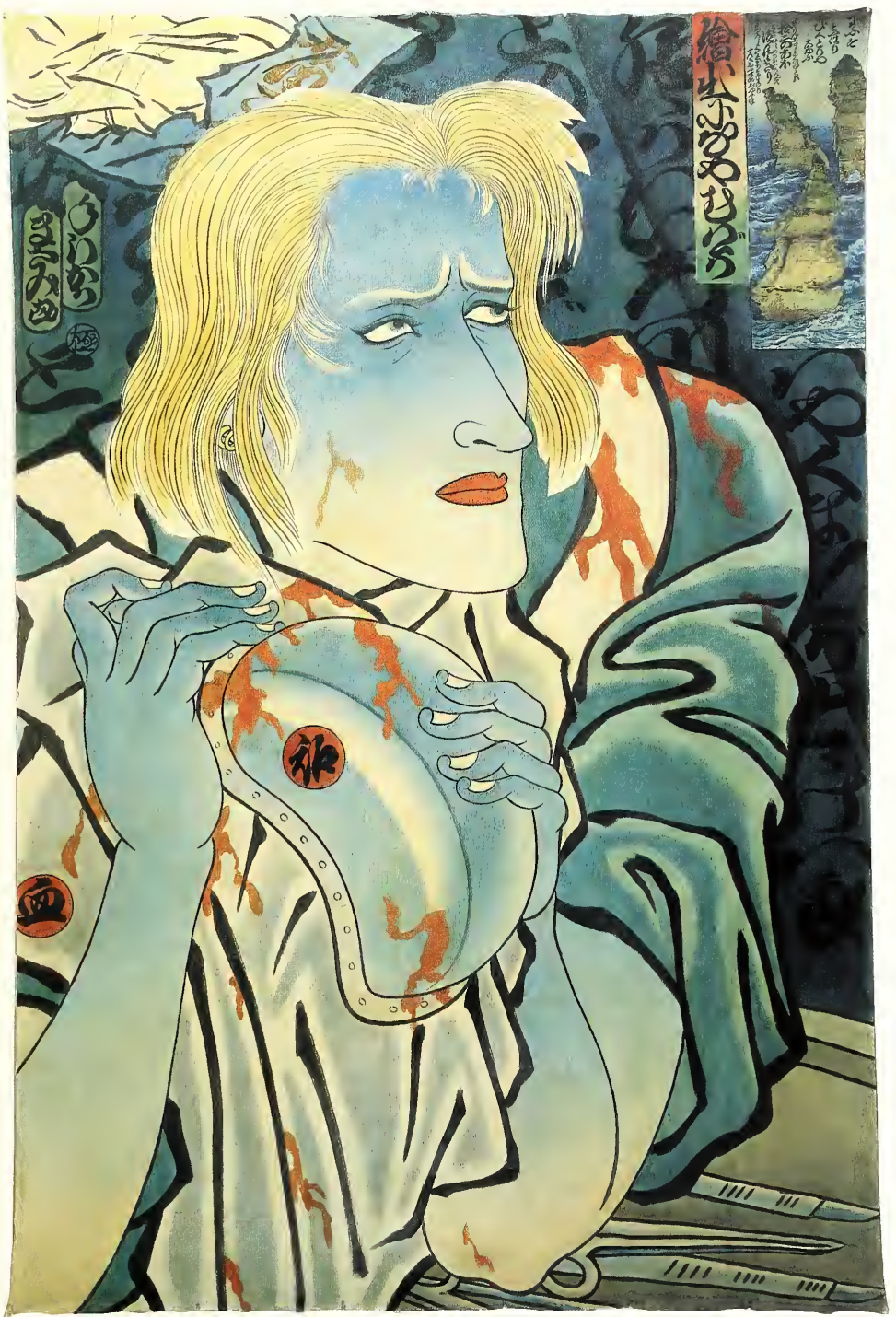


12 AIDS Series/Mother and Child

1990

Watercolor on unstretched canvas

$274.3 \times 213.4$

Courtesy of the artist

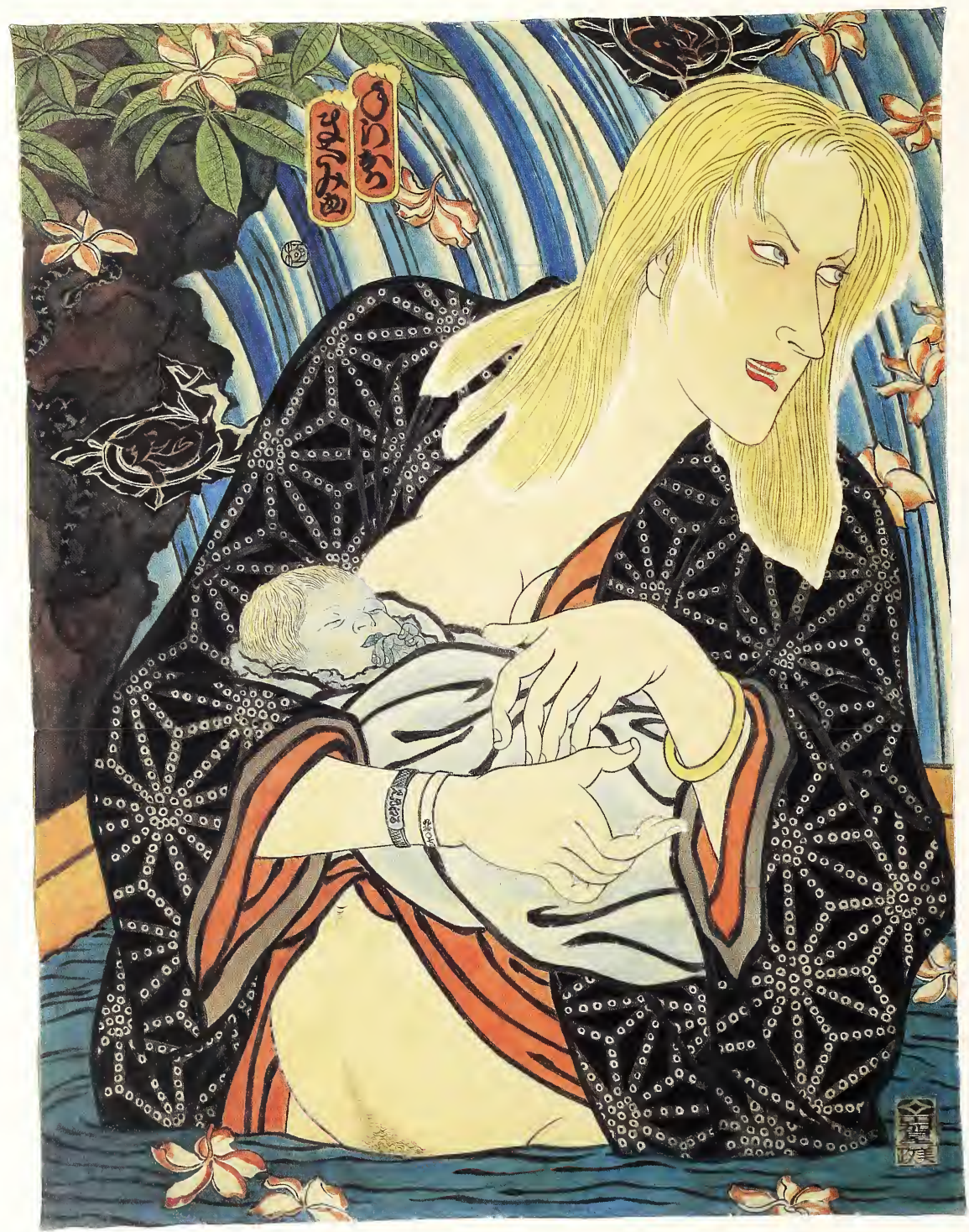


13 AIDS Series/Father and Son

1990

Watercolor on unstretched canvas

$274.3 \times 213.4$

Courtesy of the artist

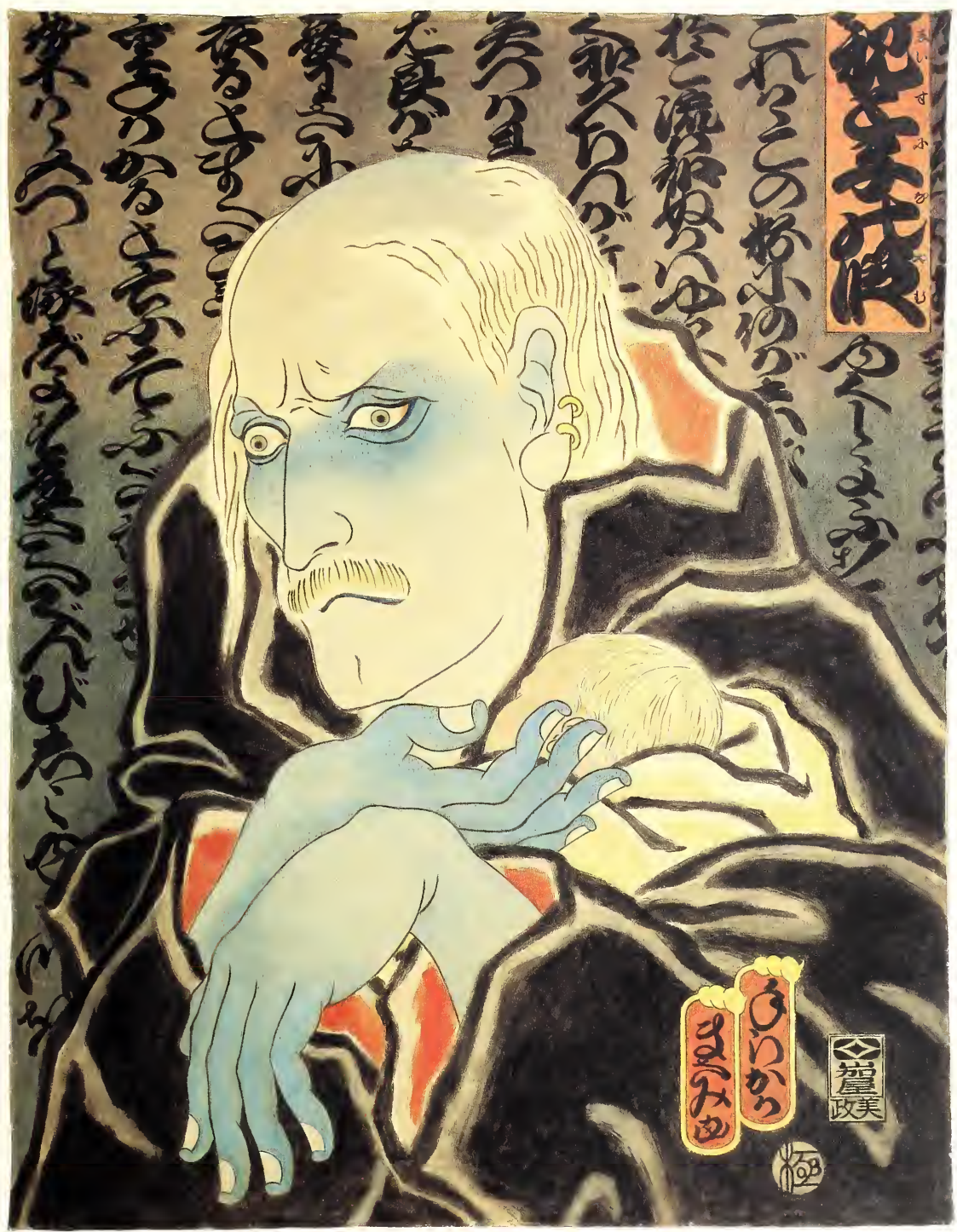




\section{I4 AIDS Series/Dody and Fox II}

1991

Watercolor on paper

$75.4 \times 111.3$

Courtesy of Misty and Lewis Gruber, Chicago

Living in the age of the AIDS epidemic, Dody fears contracting the disease. The fox tries to persuade her to navigate the dangerous path of a sexual relationship. The burning lava flow surrounding them is a warning sign to Dody of the danger that lies ahead.

Inscribed on the painting is: "The fox tells her he can guide her through safely. She cannot trust the fox unless he shows her his membership card in the 'AIDS Free' club." Since the fox is known as a trickster, Dody decides that life is too precious for just a momentary pleasure.

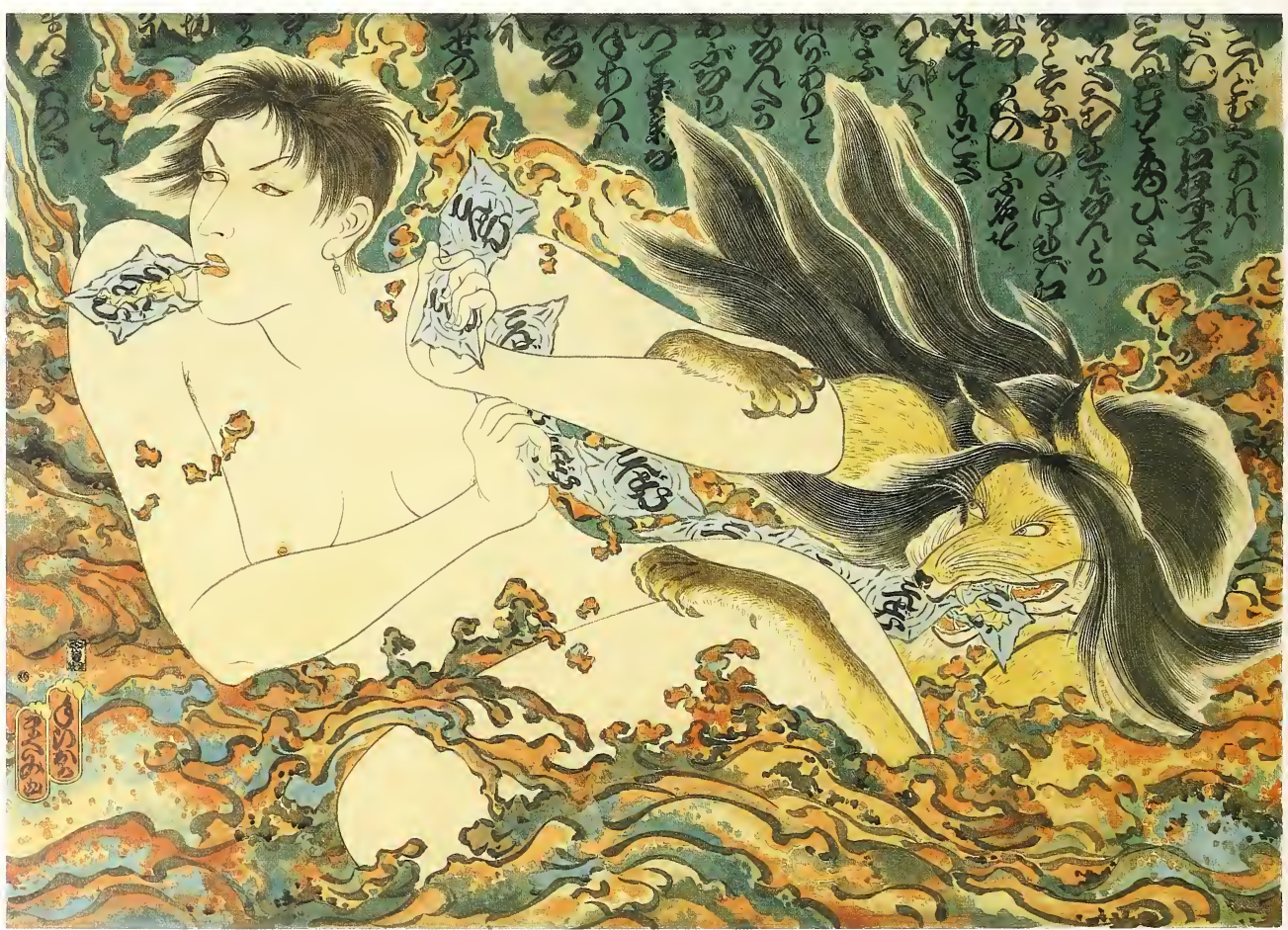




\section{New Waves Series/Sarah and Dream Octopus}

1992

Watercolor on paper

$51 \times 75.9$

Artist's collection

I am always astonished by how eloquently

Katsushika Hokusai, an ukiyo-e artist of the Edo

period, expressed eroticism in his Pearl Diver and

Two Octopuses, 1814. In considering how to rein-

terpret his work, I made a number of study draw-

ings and paintings. Times have changed since I first

explored this theme in the 1980s. For the nineties,

I thought Sarah should be careful to use con-

doms, even with her fantasy octopus

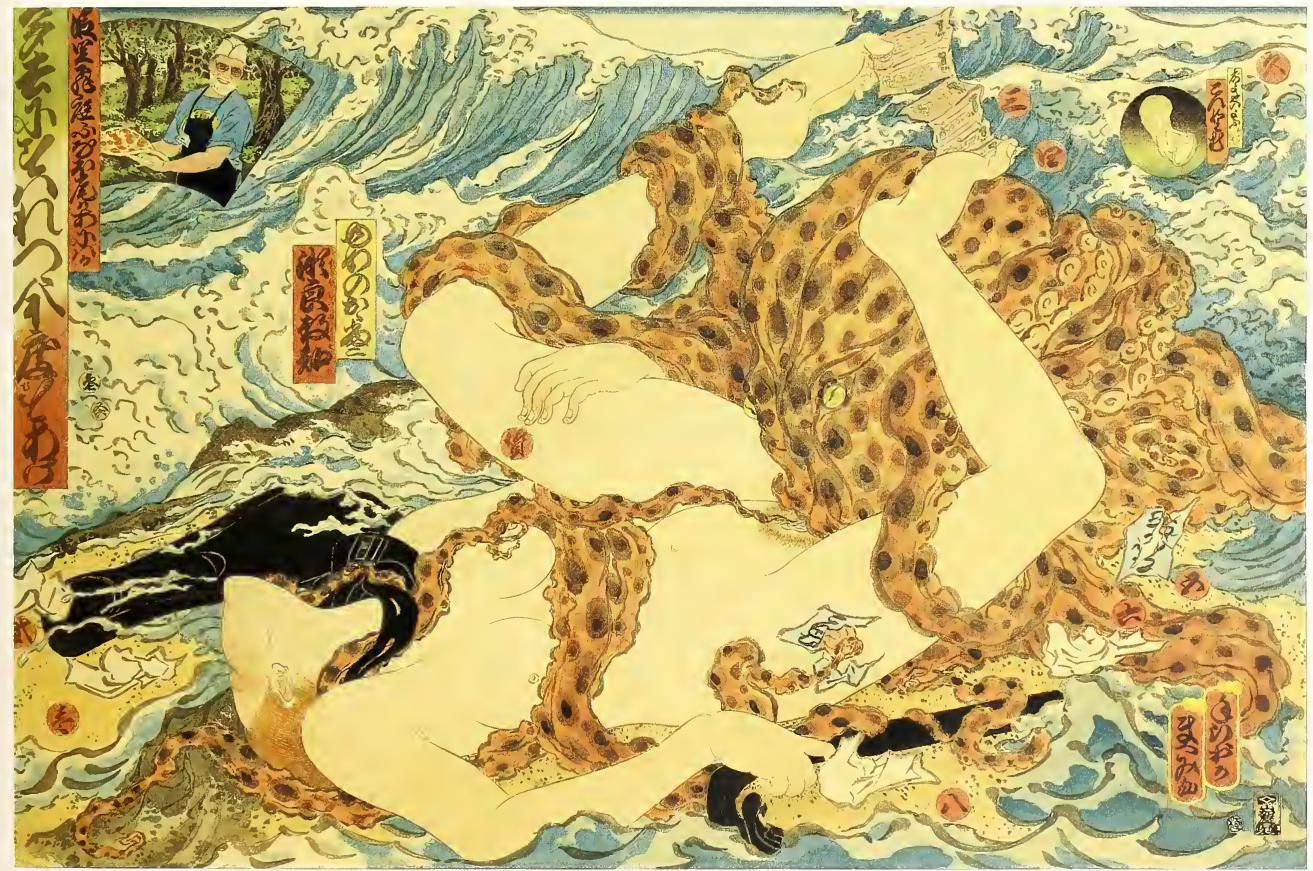


I6 New Waves Series/Female Condom Tale

1992

Watercolor on paper

$38.1 \times 56.8$

Courtesy of the artist

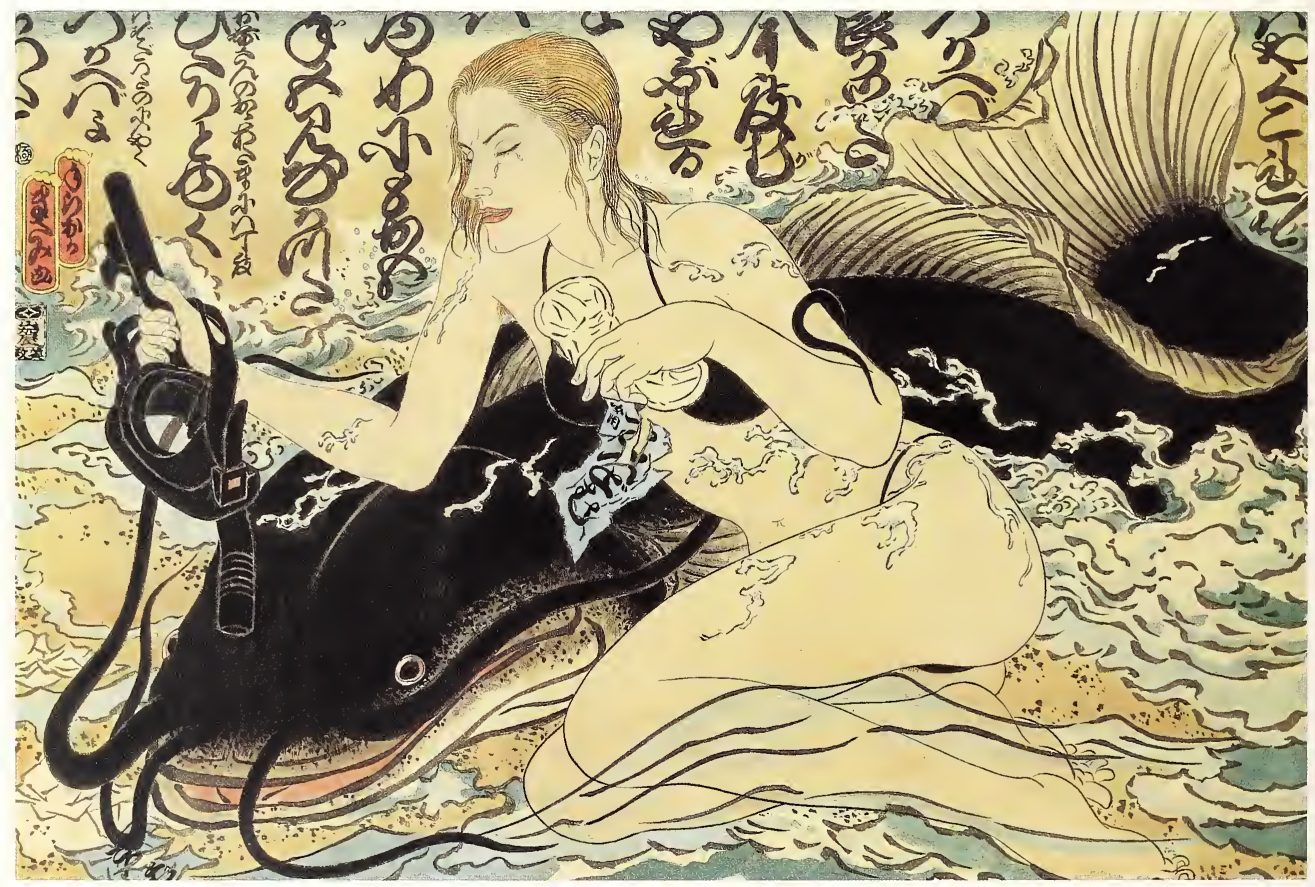


17 New Waves Series/Rabbit Island Catfish

1992

Watercolor on paper

$38.1 \times 56.8$

Courtesy of the artist

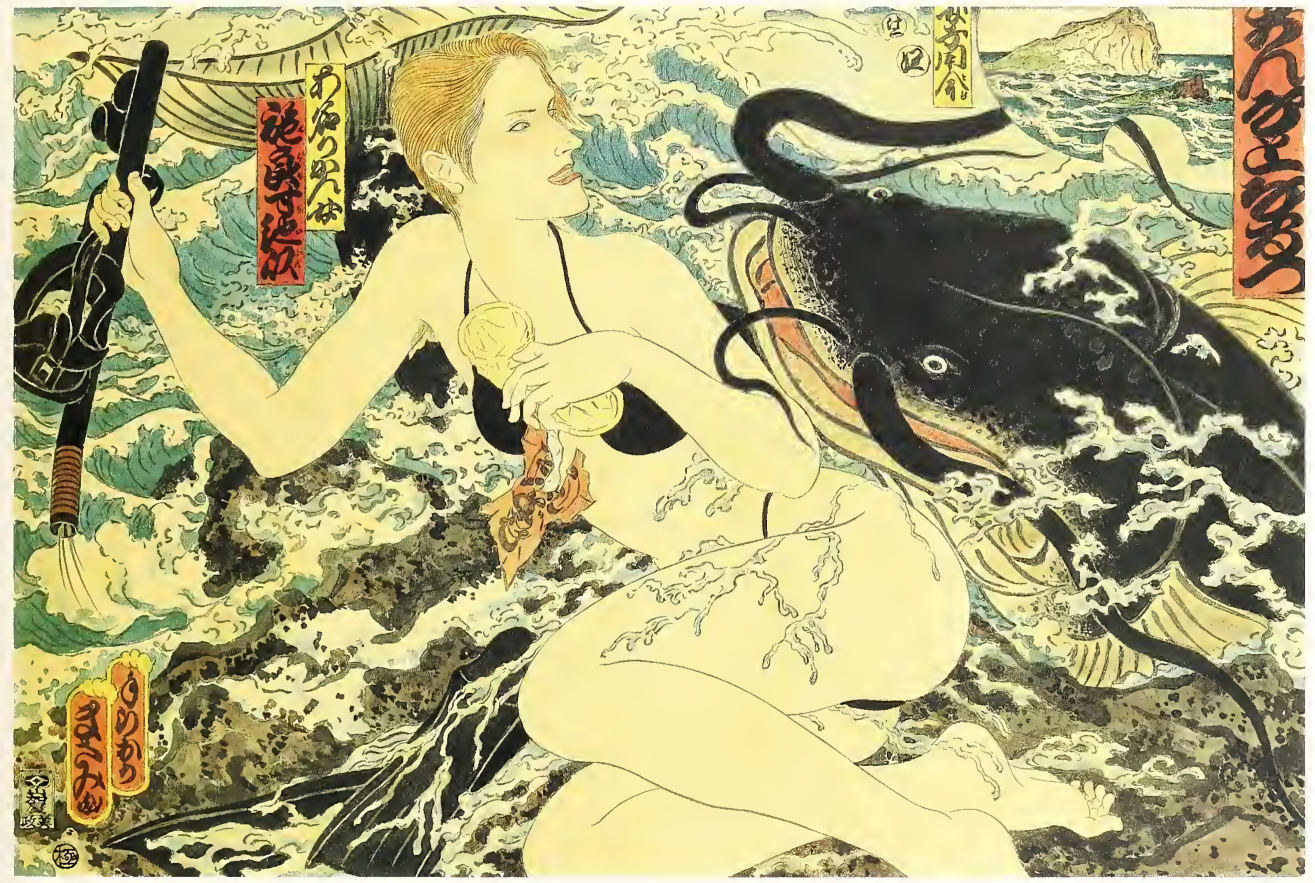




\section{New Waves Series/Makapuu Twist}

1992

Watercolor on paper

$56.5 \times 76.2$

Courtesy of the artist

A Japanese tourist emerges from the water. In front of him stands a Western woman almost losing her balance on the rocky reef. Overcome by the wondrous scene, he ponders taking a snapshot. The crucial photo opportunity disappears, however, when he takes a moment to think about his Japanese girlfriend.

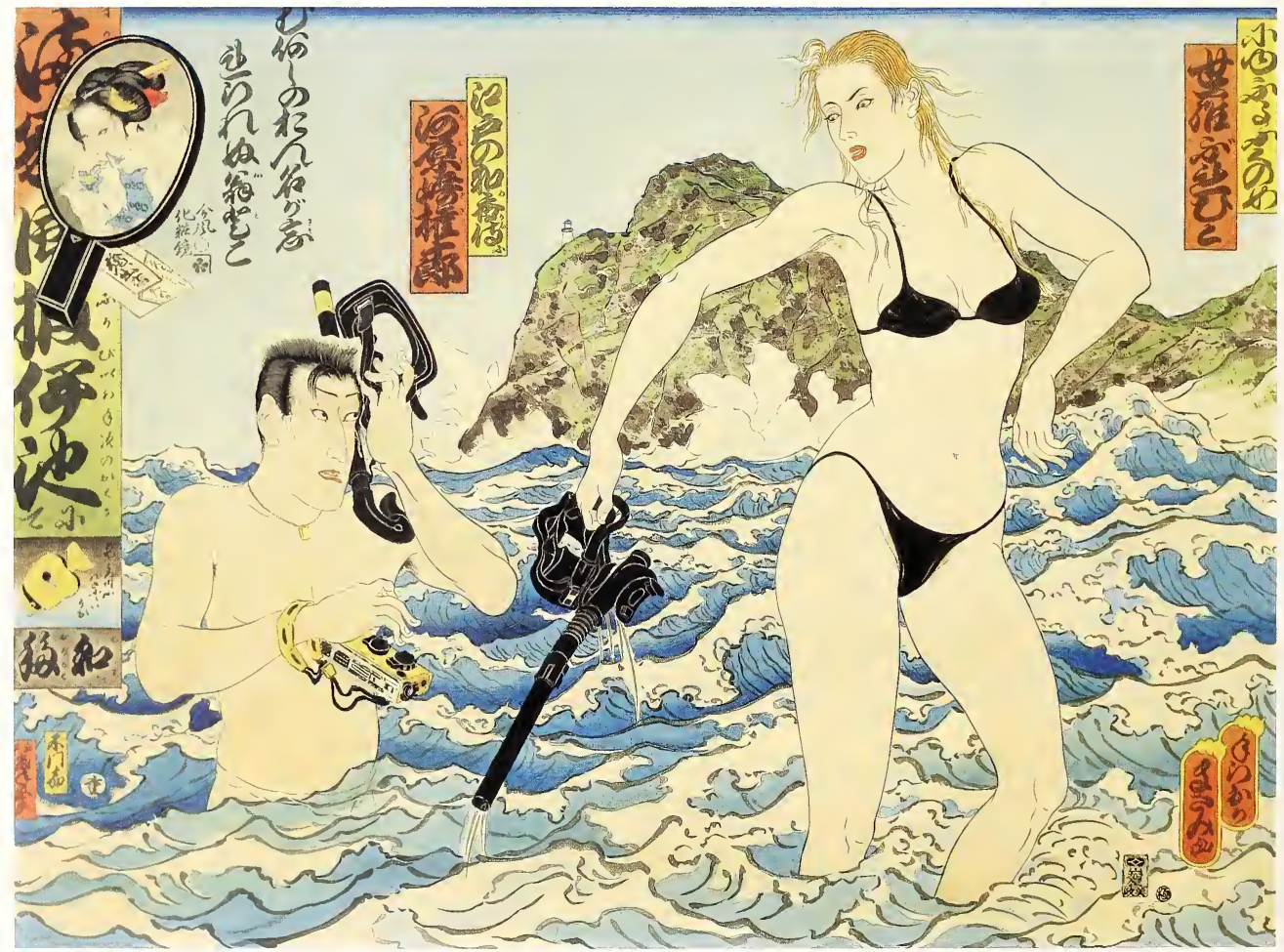


19 New Waves Series/Malibu Woman

1992

Watercolor on paper

104.1 $\times 74.9$

Courtesy of the artist

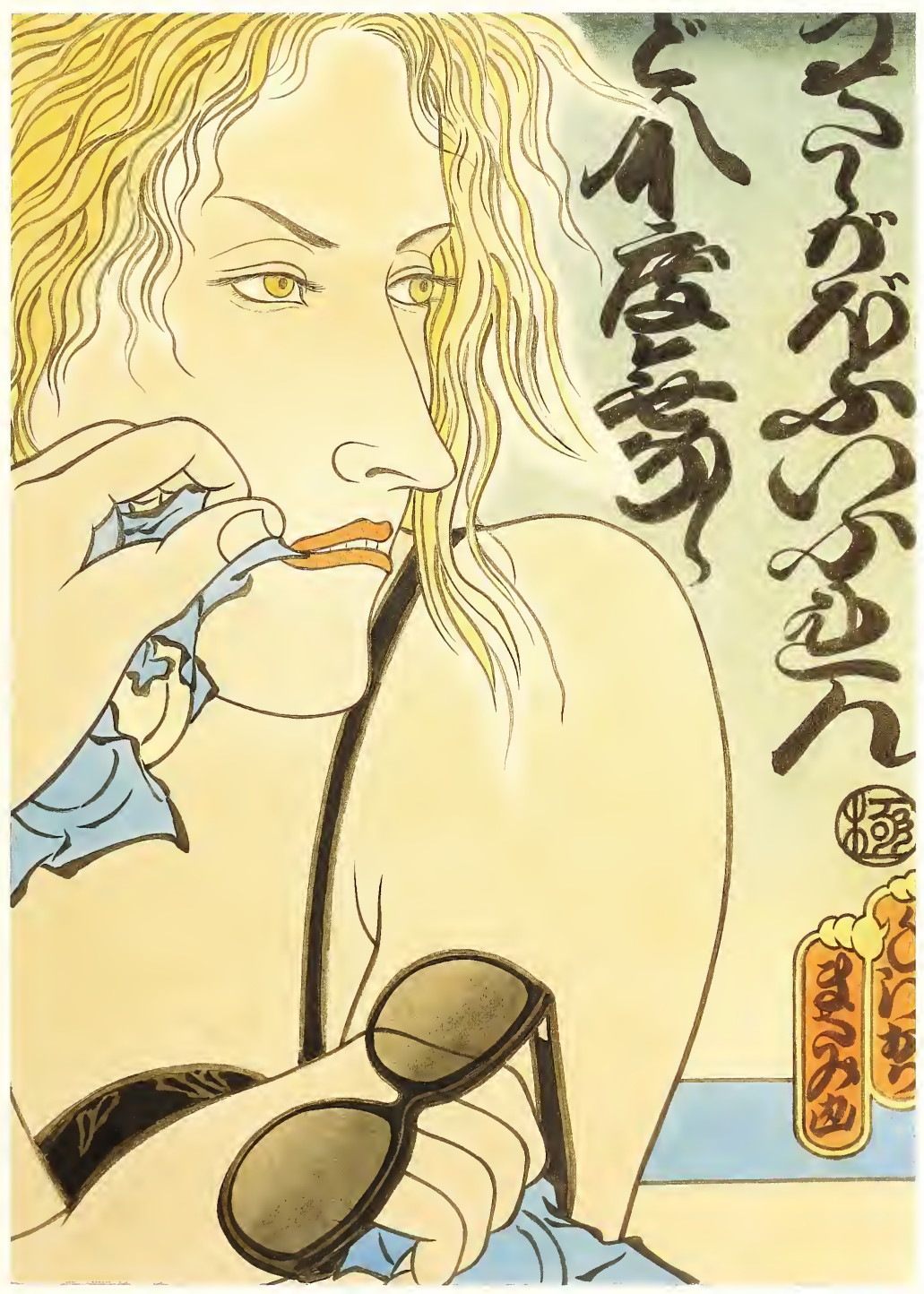




\section{New Waves Series/Eight Condom Fantasy}

1992

Watercolor on paper

$56.8 \times 76.2$

Courtesy of the artist

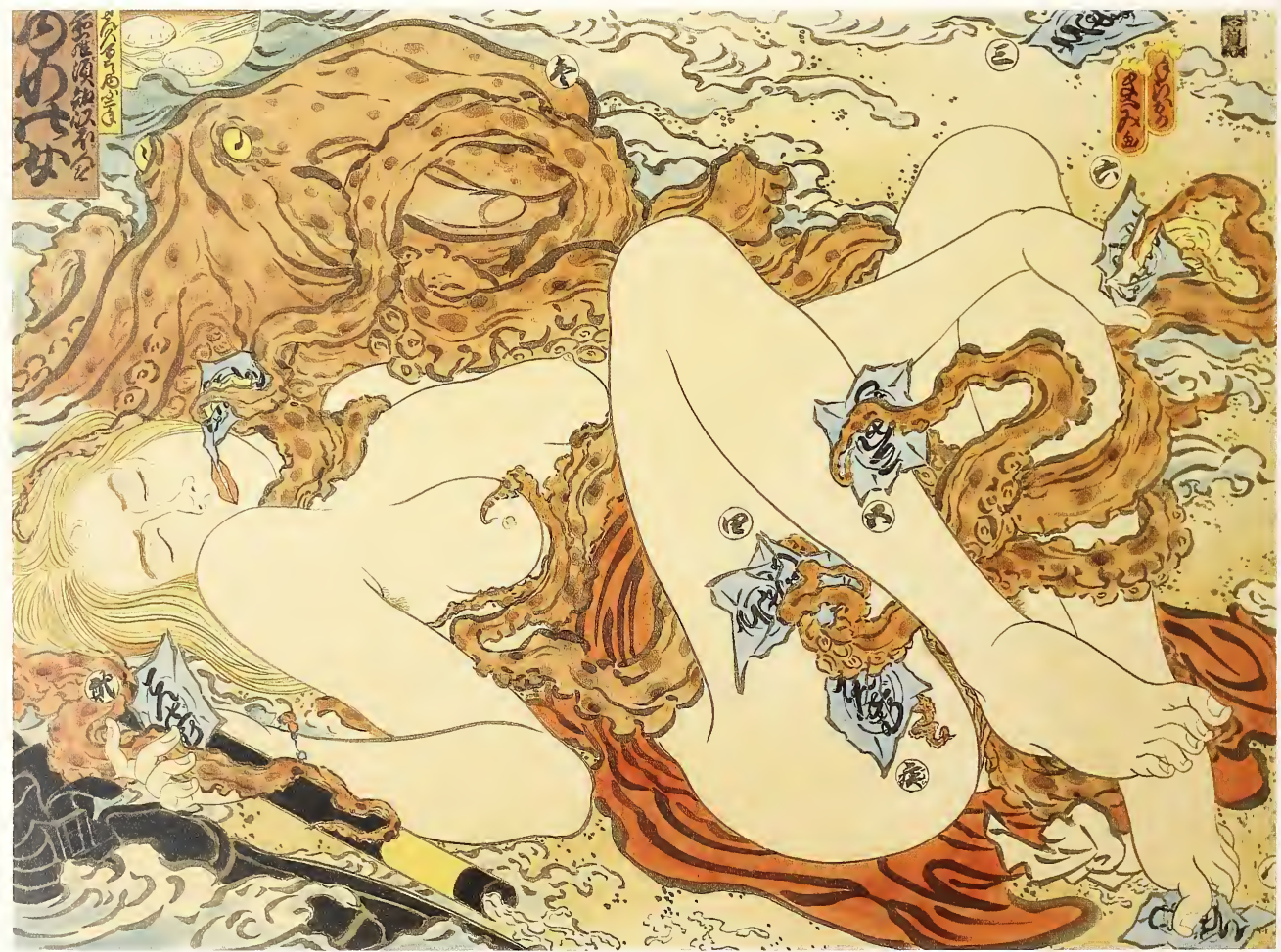




\section{I New Waves Series/Christine at Hanauma Bay}

1992

Watercolor on paper

$57.2 \times 75.2$

Courtesy of the artist

I depict traditional Japanese men as samurai.The younger man shown here is more Westernized, as signified by his punk hairstyle. Both are male chauvinists, or perhaps they are just in awe of American women. As Christine walks by, she feels their intense stares on her back.

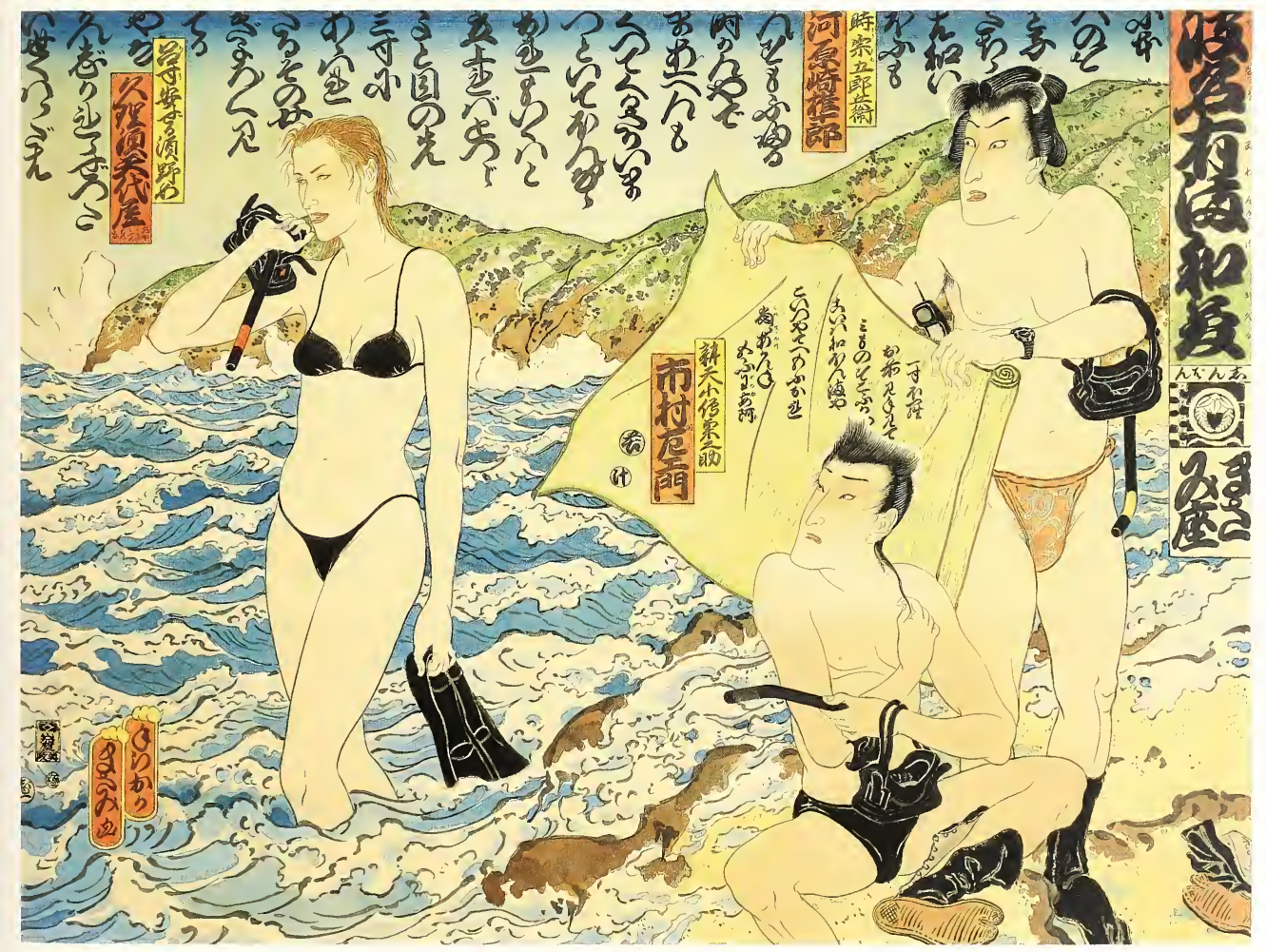




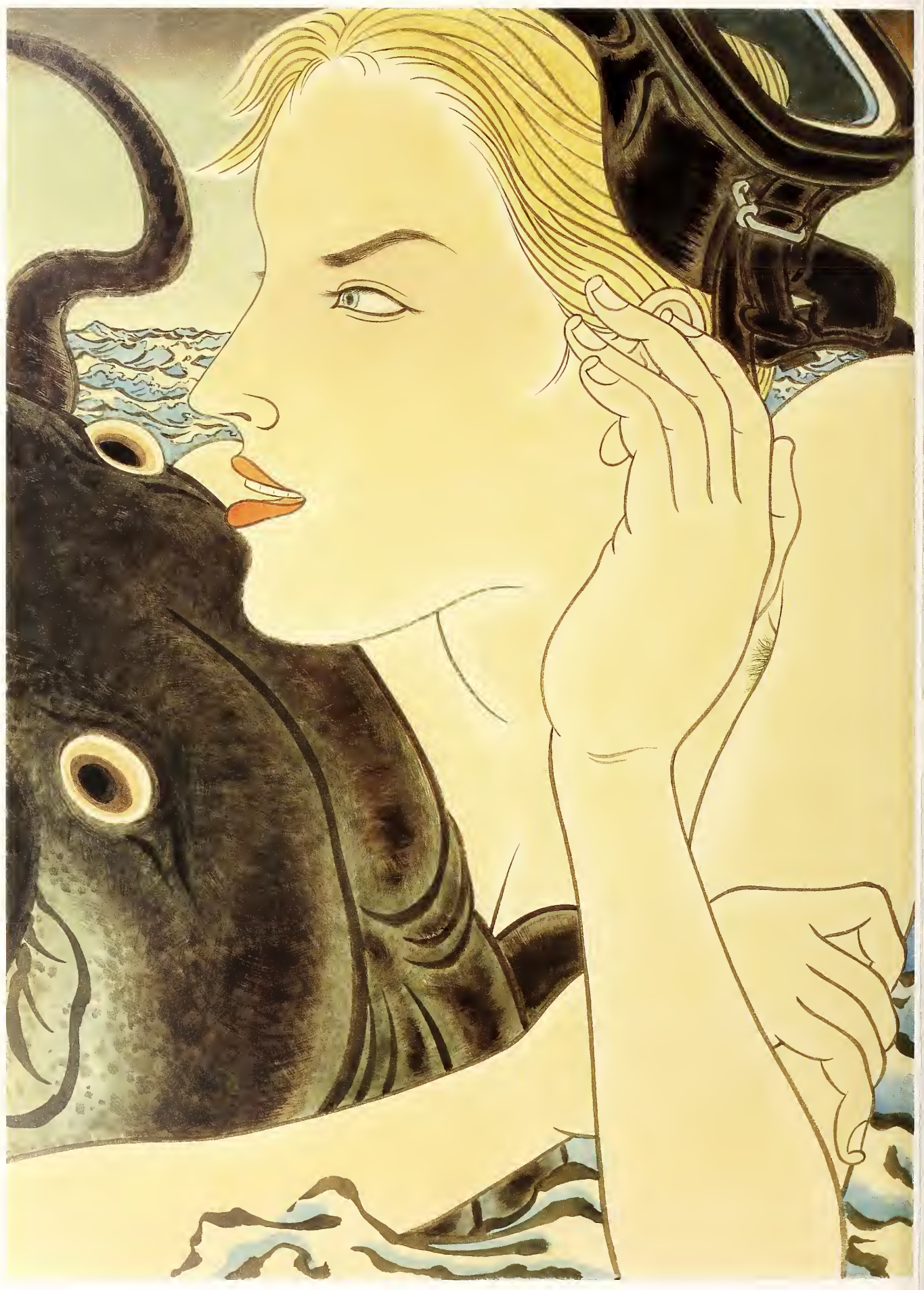




\section{Hawaii Snorkel Series / Kunisada Eclipsed}

\section{3}

Woodcut, etching, and aquatint on paper

$66 \times 115.6$

Courtesy of Tyler Graphics, Mount Kisco, N.Y.

I often wish my sensei (teacher) Utagawa Kunisada

(I786-1865) were alive. I would love to see how and what he would draw in America. I depict a fantasy scene of Kunisada in Hawail watching the solar eclipse. His view is obscured by the sight of an American woman who diverts his attention, changing his sightseeing plans, as well as eclipsing the eclipse.

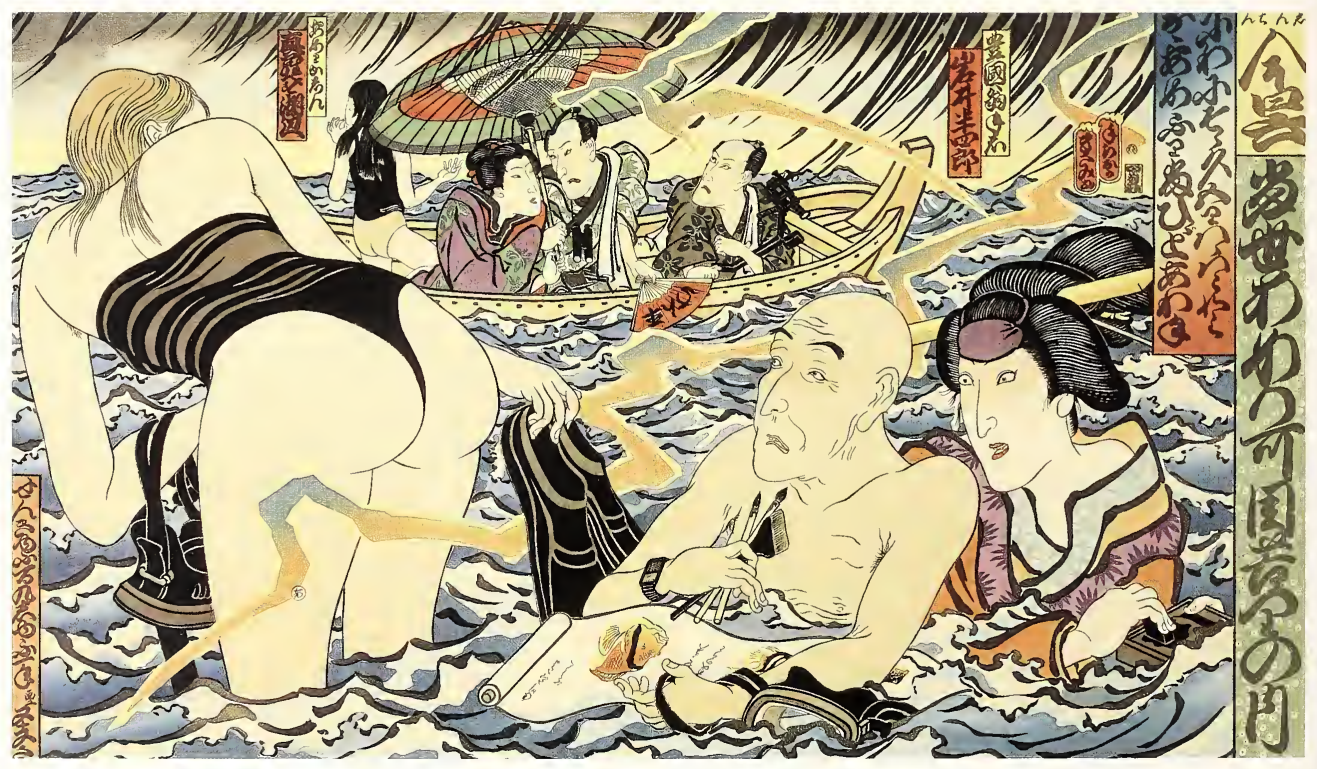




\section{Hawaii Snorkel Series/Longing Samurai}

\section{3}

Woodcut, etching, and aquatint on paper

$64.8 \times 97.2$

Courtesy of Tyler Graphics, Mount Kisco, N.Y.

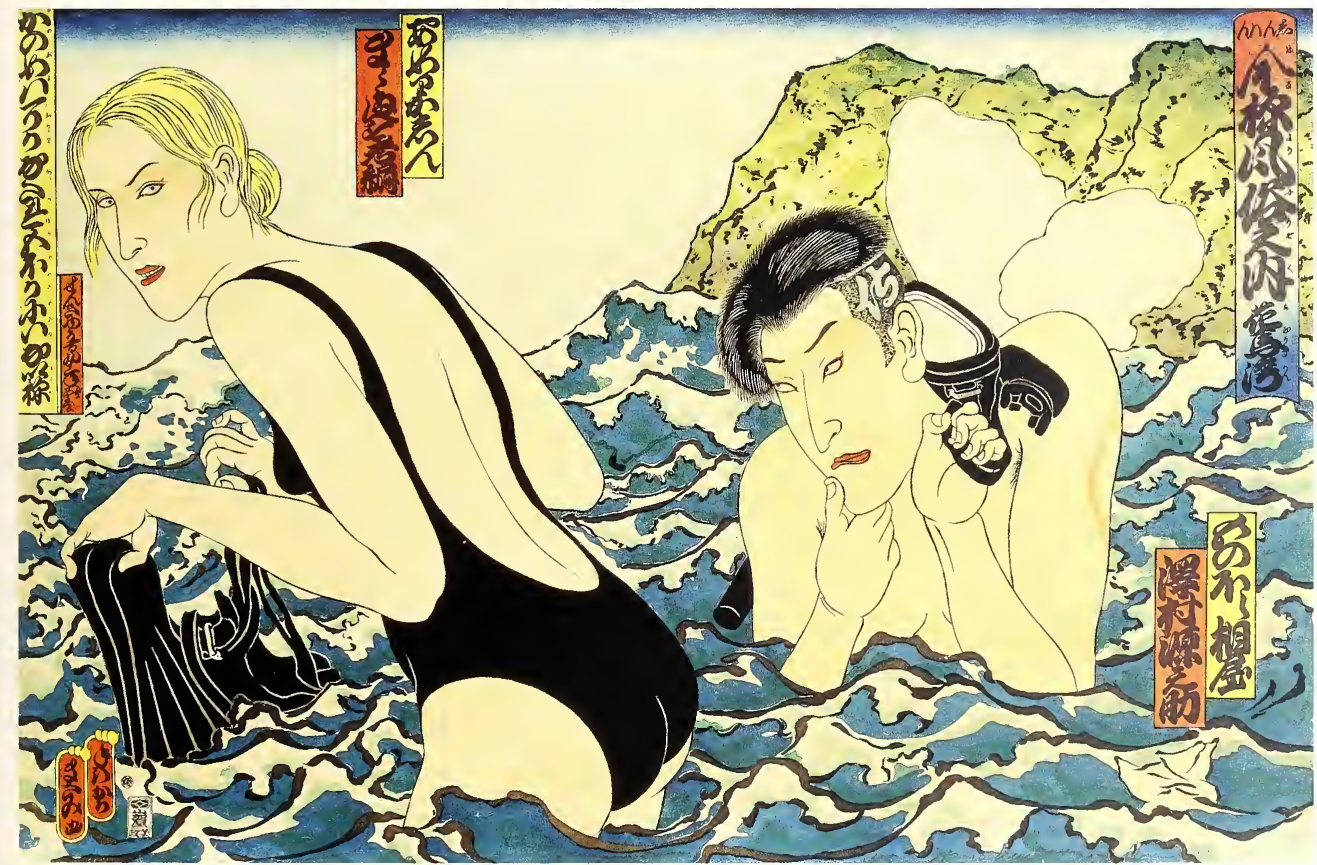




\section{Hawaii Snorkel Series/Catfish Envy}

\section{3}

Woodcut, etching, and aquatint on paper

$67.9 \times 97.8$

Courtesy of Tyler Graphics, Mount Kisco, N.Y.

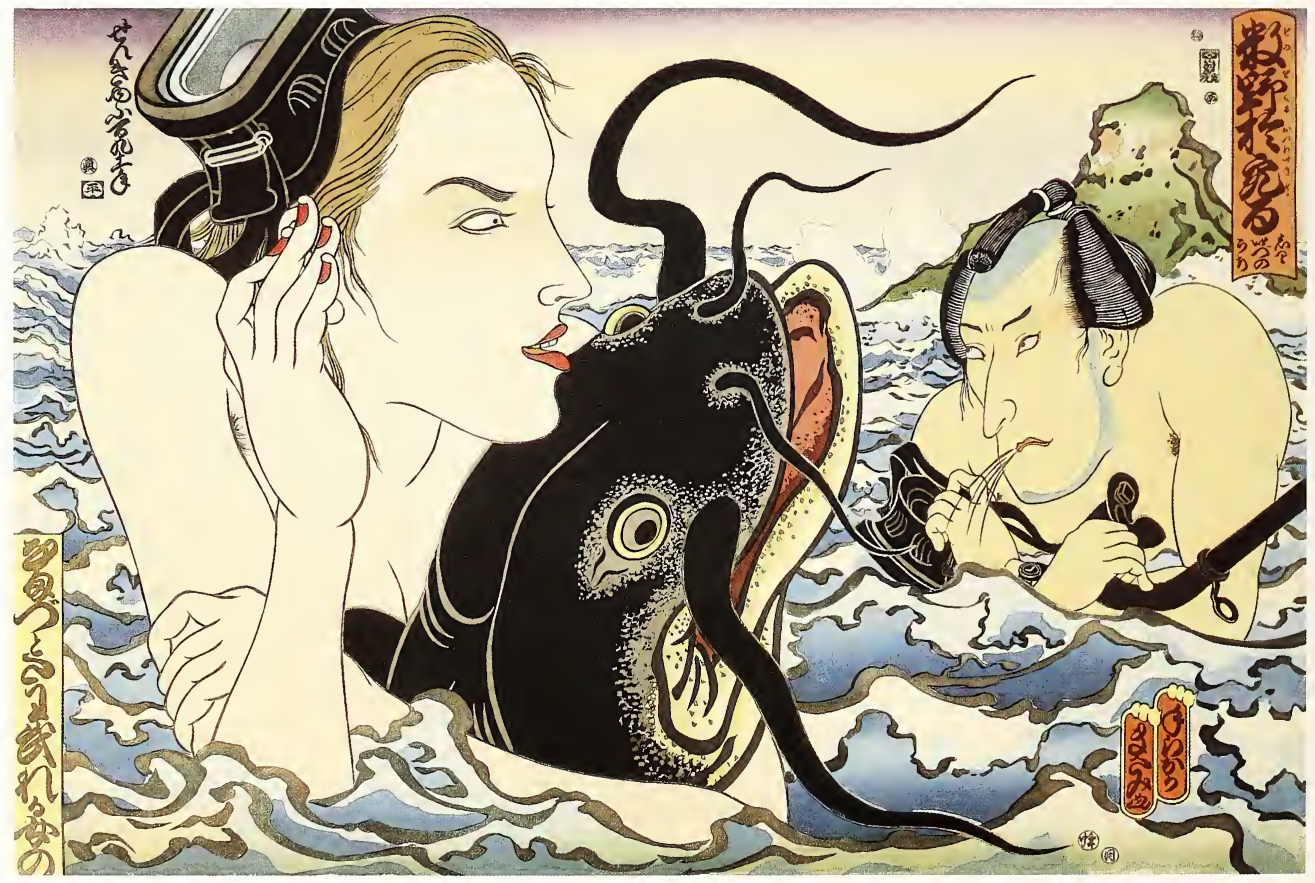




\section{Tale of a Thousand Condoms/Samurai and Razor}

1989

Watercolor on unstretched canvas

$212.7 \times 332.1$

Courtesy of the artist

In Japan, samurai would never have tattoos. The tattoo is still considered a lower-class macho symbol, traditionally practiced among yakuza (gangsters) and construction workers. A samurai with a tattoo could exist in America, where I painted this picture, because there are no such class restrictions. The recent phenomenal popularity of tattooing shows how liberated American people are. If people like something, nothing keeps them from pursuing that desire.

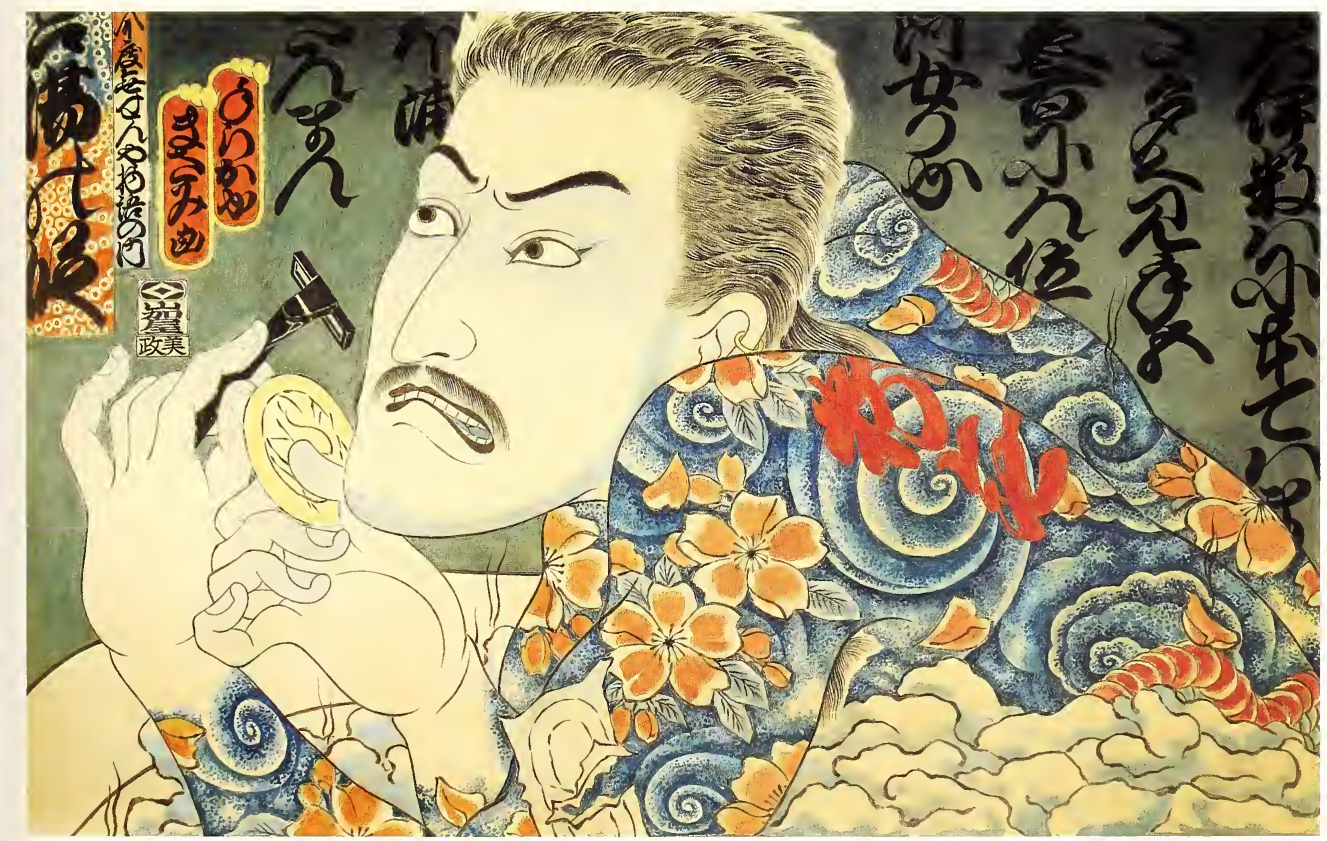




\section{Tale of a Thousand Condoms/Geisha and Skeleton}

1989

Watercolor and sumi-e ink on unstretched canvas $337.8 \times 209.6$

Courtesy of the artist

When the fear of AIDS first spread in Japan, people acted as if it was not their problem or even a reality. Perhaps it could only happen in the pleasure quarter? Or maybe in the floating world of a geisha house? This scene represents a geisha's uncontrollable fear of contracting AIDS.

Thinking about AIDS, a geisha holds several condoms as she awaits her customers for the evening. Suddenly, a cold draft creeps through her shoji window. The haunting sound of a winter wind is heard in the distance. Soon the fingers of a skeleton pull the shoji screen open. The geisha feels a chill in her body as she senses the supernatural power approaching her.Without making a sound, bony fingers grasp the windowsill, pulling the skeleton's head into view. A former customer, who died of AIDS, has come back for a visit. The geisha views the skeleton, recognizing her former customer. Inscribed on the painting is this conversation:

Geisha: On my God, it's you that came back?

Skeleton: Yes, it's me again. I took a subway to get here. I felt bad on the train because everybody was afraid of me. 


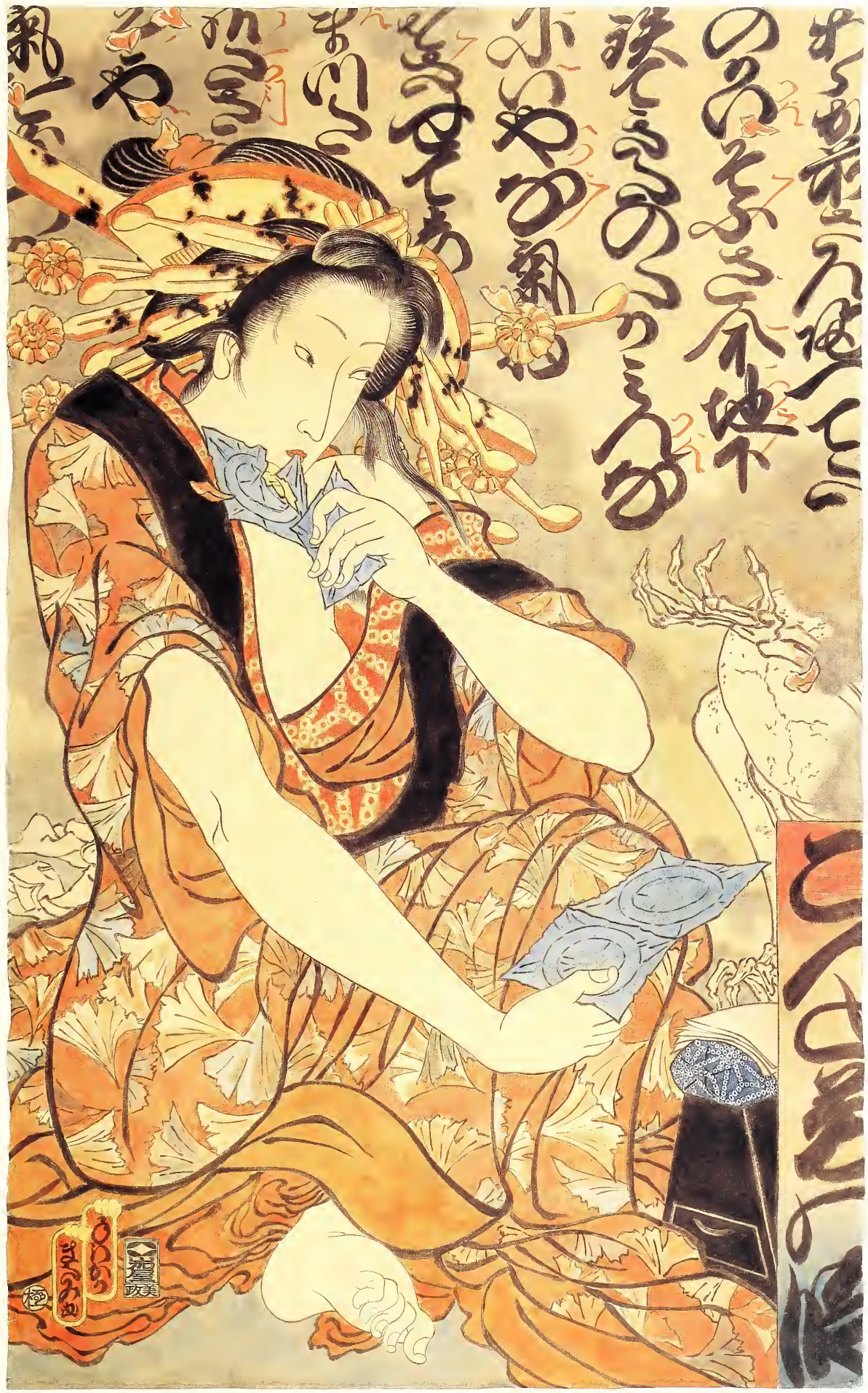




\section{Tale of a Thousand Condoms/Mates}

1989

Watercolor and sumi-e ink on unstretched canvas

$207 \times 345.4$

Artist's collection

I love the rich, dark color of people's clothing and the bright red buses in London. And British green. I especially love London taxis, which remind me of shiny beetles. They are very sensuous and tactile and the interior particularly appeals to me. The sofa and folding chair in the back of large London taxis make my fantasies expand. How many people view this as a sexy arrangement? I imagined a couple in the back of a London taxi. Perhaps a Japanese punk boy is anxious to get to his girlfriend's apartment. The inscription reads::
London Woman: Would you calm down, please? We are near Kensington Street, where my apartment is.

Punk Boy: Great! I bought a bunch of condoms for tonight.

There is a warning written on the English condom package - - "Do not use twice!' The London Woman imagines she has to worry about contraceptives. Why do women have this responsibility? How come men do not have to worry over these preparations?

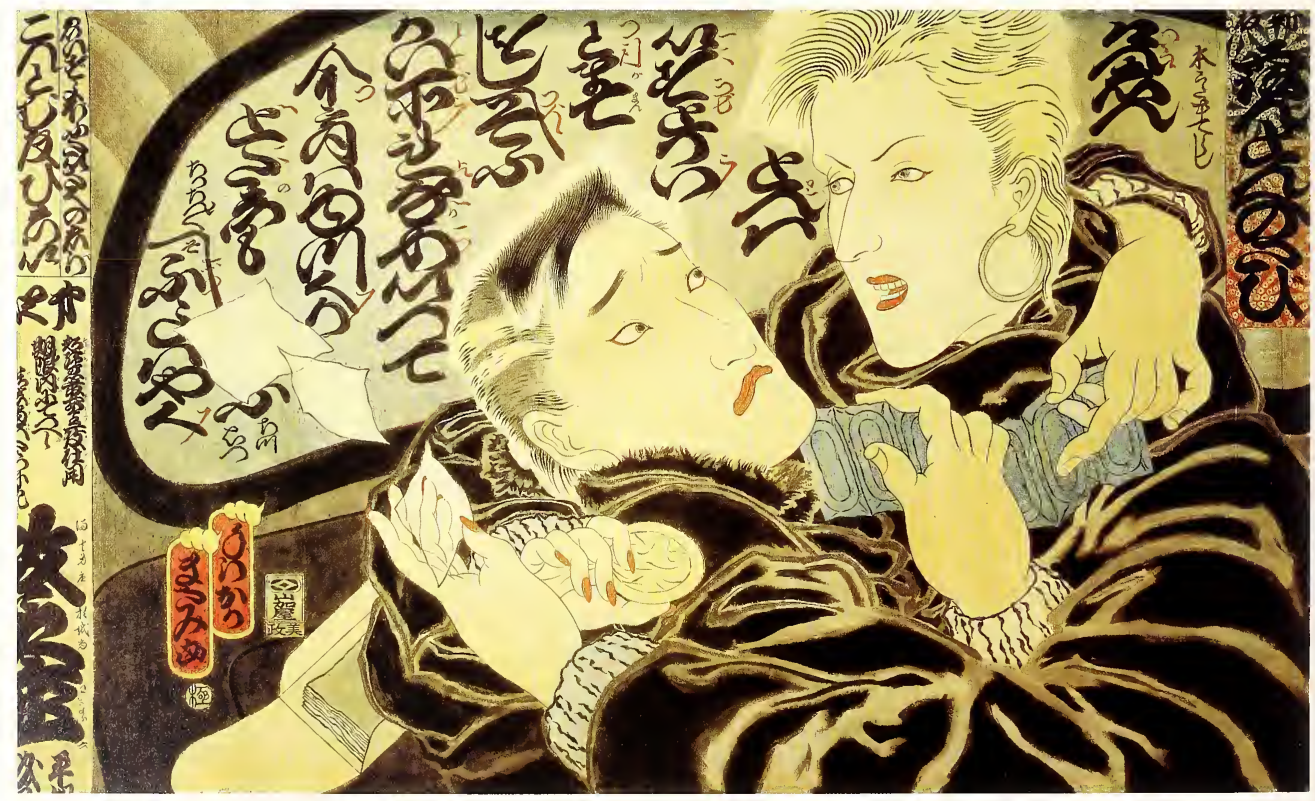


1993

Watercolor on paper, mounted as a scroll

$302.7 \times 144.1$, scroll

Courtesy of Pamela Auchincloss Gallery, New York

A woman on the tube (subway) at Camden Station in London grasps her handbag. As it changes into an imaginary eggplant, her thoughts drift to fantasy She daydreams that she has become Eve in the Garden of Eden. A giant snake crawls around her, trying to seduce her. Eve prepares to eat a pomegranate that the snake has given her Suddenly a ninja appears to rescue her from the temptation. Instead of throwing the usual shurikens (small knives) to assassinate his opponent, the giant snake, the ninja throws safe sex condoms to Eve, successfully saving her life. In the lower right-hand corner is inscribed: "Camden Subway Station, London Woman."The upper left comer says "Eve."

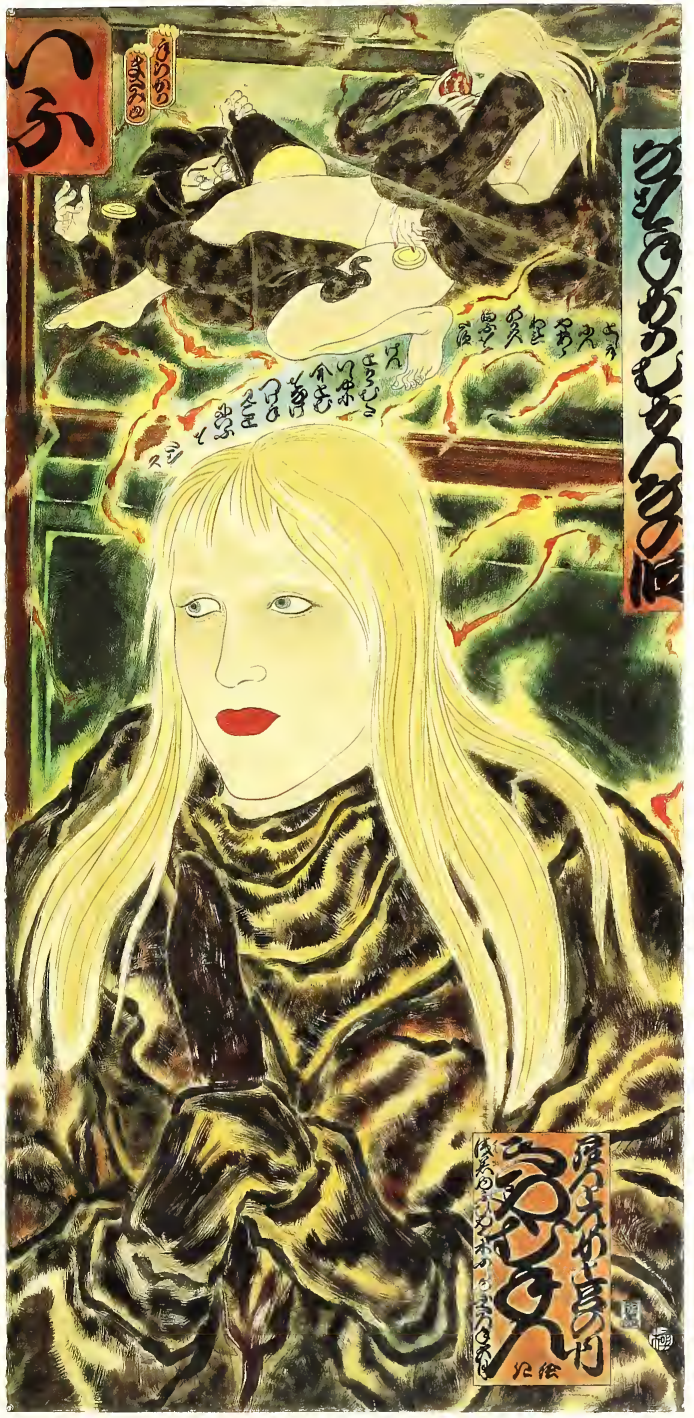




\section{Tree of Life Series / Eve with Eggplants}

1993

Watercolor and gold leaf on paper, mounted as a scroll $274.3 \times 100.3$, scroll

Courtesy of Misty and Lewis Gruber, Chicago

Eve, fresh from the Garden of Eden, strolls in a Bosnian war zone. Although Bosnia is not particularly known for an AIDS epidemic, the fear of contracting AIDS worries her. Adam is already dead, crushed under the snake. The cause of his death is unclear. Did he die of AIDS or was he hit by a bullet? With educational eggplants, Eve needs to learn how to use condoms before she can express her sexuality. This is not the earth she expected when she left paradise. 


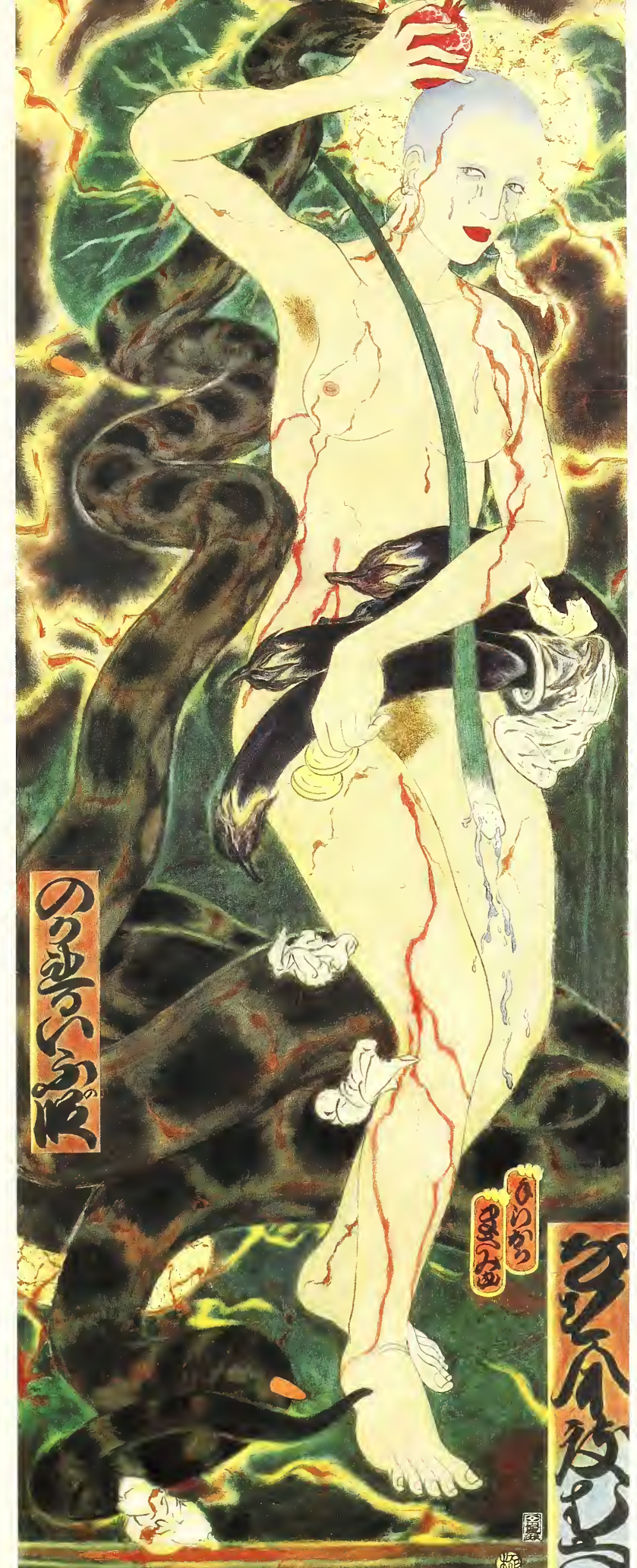




\section{Tree of Life Series/Eve with Cucumber}

\section{3}

Watercolor and gold leaf on paper with construction

$157.5 \times 74.3 \times 15.2$

Courtesy of Pamela Auchincloss Gallery, New York

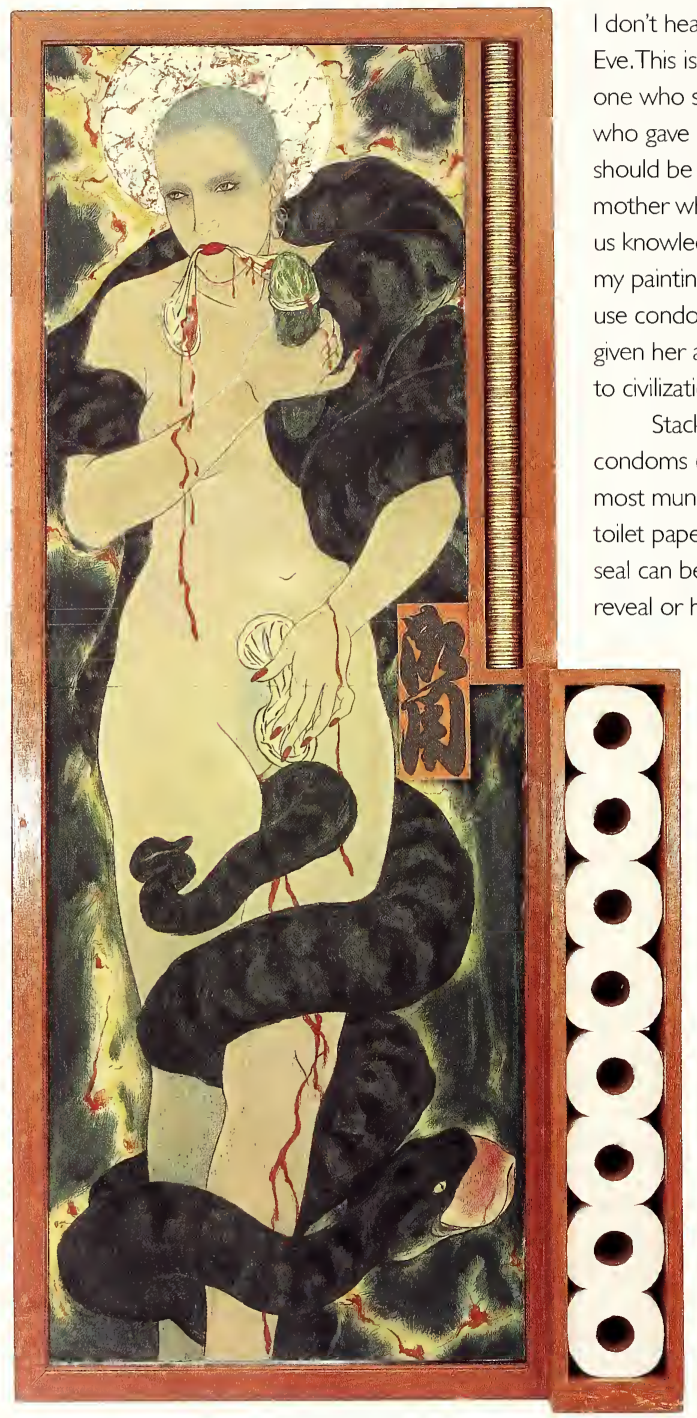




\section{Adam and Eve/Malibu Fire}

1995

Watercolor on paper

$234.3 \times 151.8$

Courtesy of Pamela Auchincloss Gallery, New York

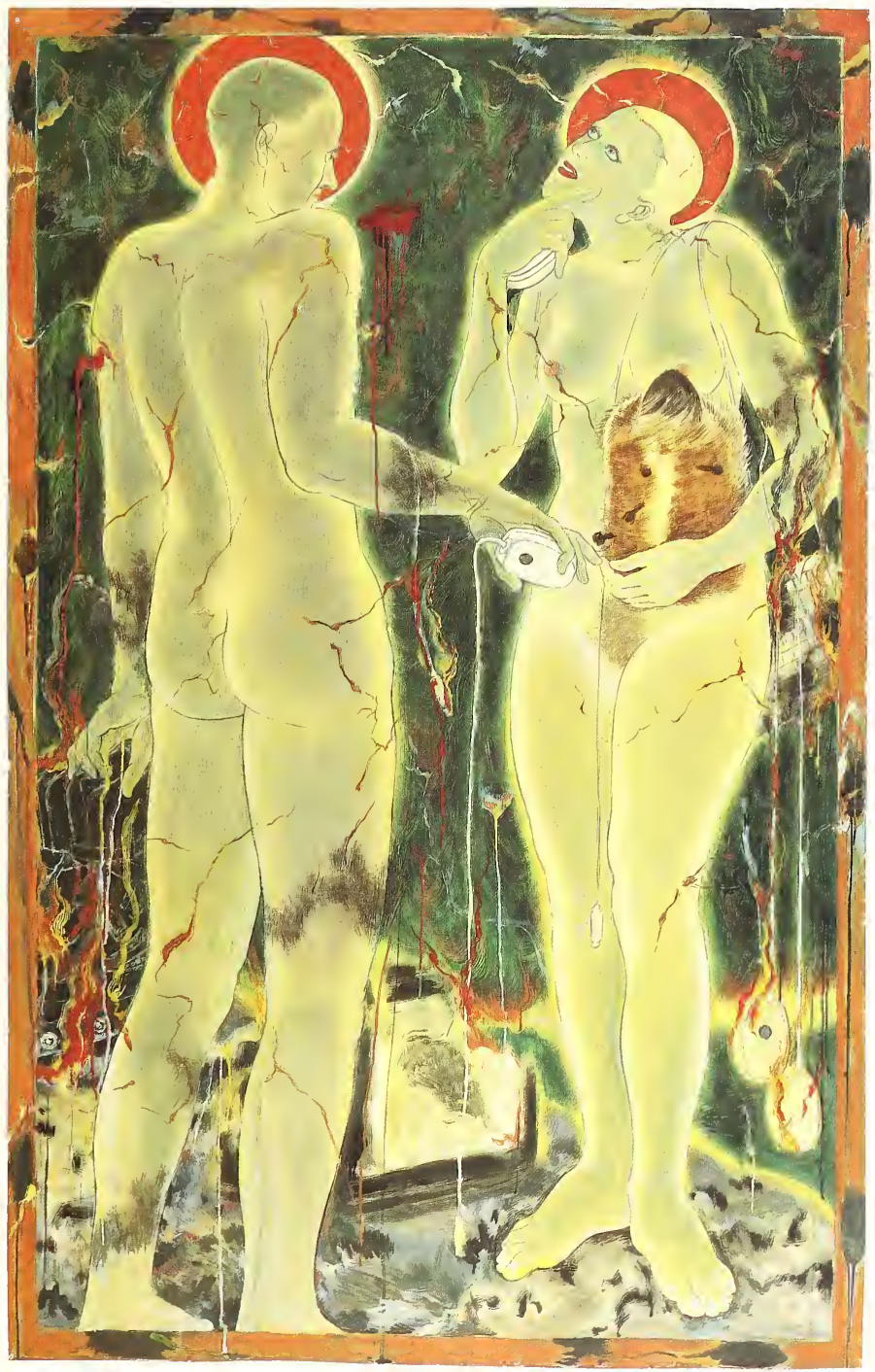




\section{Adam and Eve/Surge Protector}

1995

Watercolor on paper

$233.7 \times 106.7$

Courtesy of Pamela Auchincloss Gallery, New York

In the painted world of Hieronymus

Bosch (ca. |450-15|6), Adam and

Eve did not have condoms and computers. When Adam and Eve descend from heaven this time around, they are caught in a spiderweb of modern technology. They don't need to see other humans in person because they can find friends through e-mail and communicate with "electronic people." By moving a mouse they can travel, visit virtual museums, and learn about nature and animals, including the ones that are extinct. They can even study the paradise they lost! Adam and Eve are seduced by the American lifestyle. They enjoy this virtual life, but when the mouse no longer moves and the computer shuts down, they panic. They are Americans now!

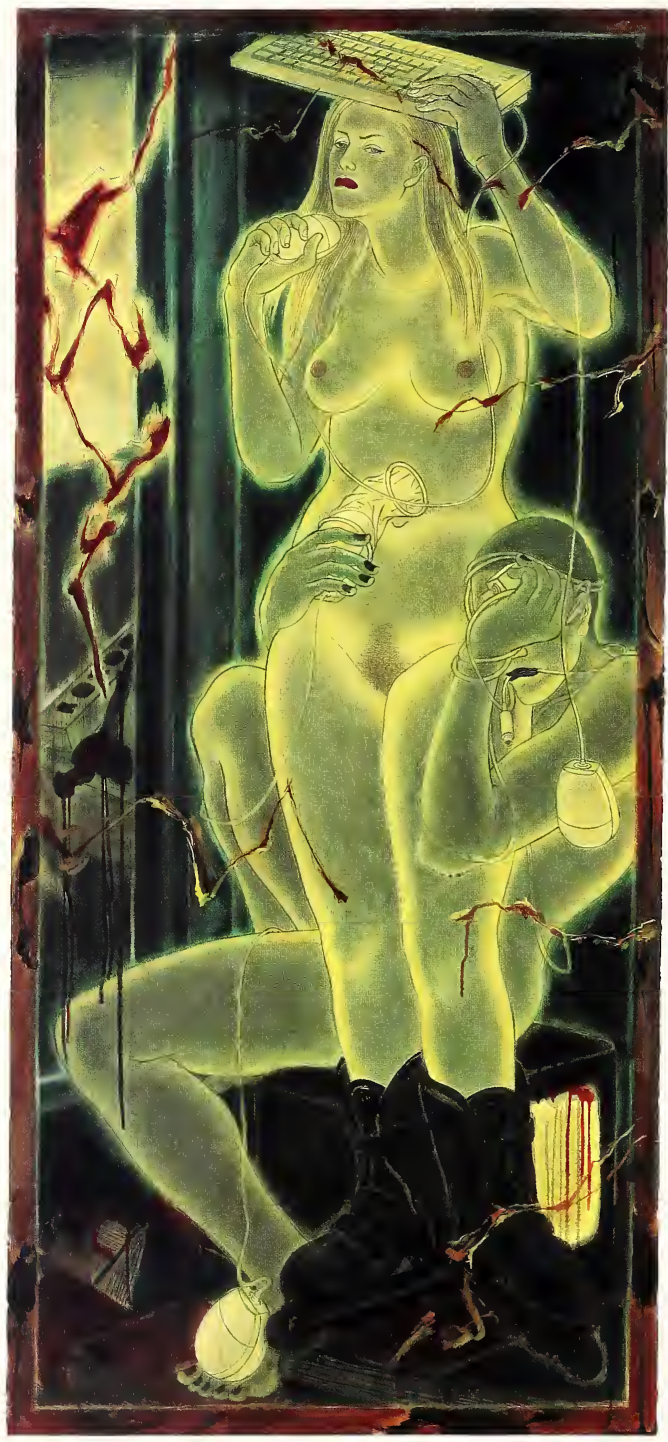




\section{Adam and Eve/Virtual Reality}

1995

Watercolor on paper

$233.7 \times 106.7$

Courtesy of Pamela Auchincloss Gallery, New York

Adam, dead of AIDS, has returned to earth as a skeleton because he longs for Eve. This time, when he wants to make love with her, he is more cautious, using a female condom in order to protect them both from the AIDS virus.

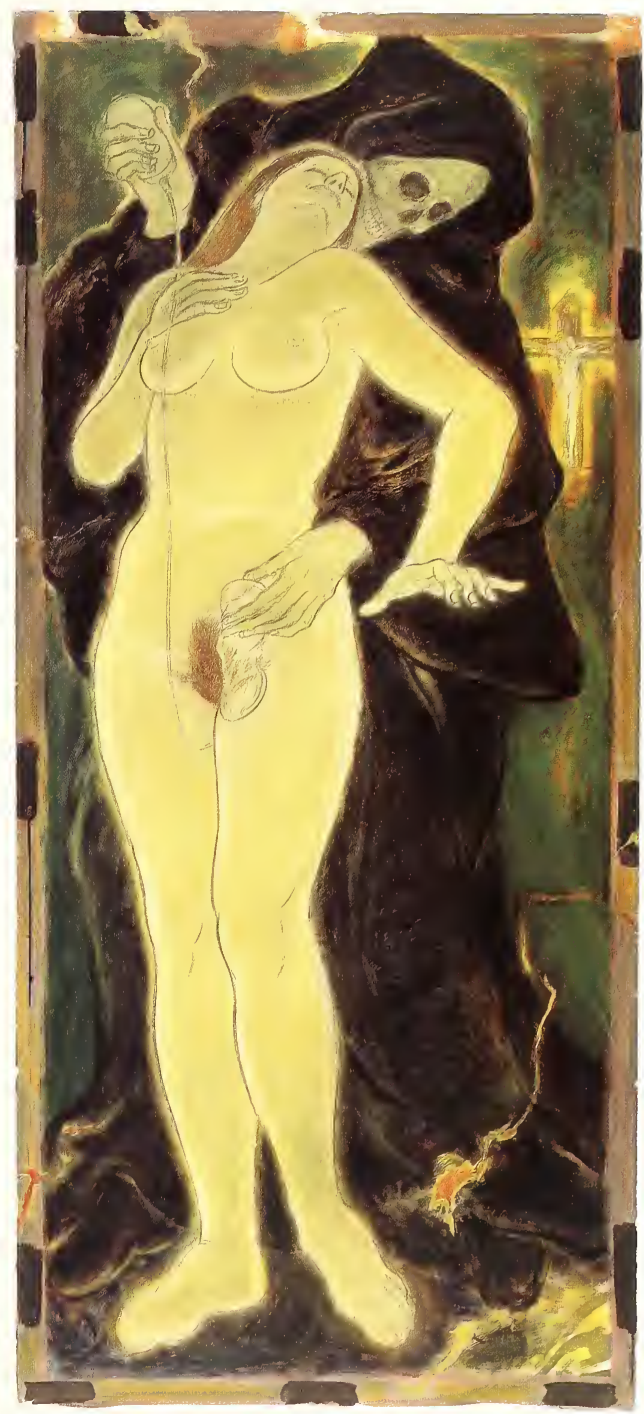




\section{Adam and Eve/Mousetrap}

1995

Watercolor on paper

$228.6 \times 162.6$

Courtesy of Pamela Auchincloss Gallery, New York

My personal high-tech revolution started late in my life. When I was fifty, I started watching television. This eventually led to my possessing a fax machine and a personal computer. Now, getting the most advanced equipment and programs is almost an addiction. I have to admit I am an obsessed consumer.

Mouses are all over the house and the neighborhood. With high tech, we must use tremendously high voltage, which might overload the electrical wires and cause a blackout. Then trees would get blamed (a notorious power outage in Hawaii was blamed on a "killer tree"), and crews would be chopping down ancient trees all over town.

I wondered how Adam and Eve would adjust to modern high-tech culture. We are all being trapped by computer mouses, so perhaps Adam and Eve would be the same. The high-technology/cyberinformation highway is spreading virtual asphalt globally. My Adam and Eve are perhaps the first casualties of this high-speed rush hour.

But a computer helps my writing, and sometimes I use it to draw sketches. It's OK to have a personal computer, isn't it? 


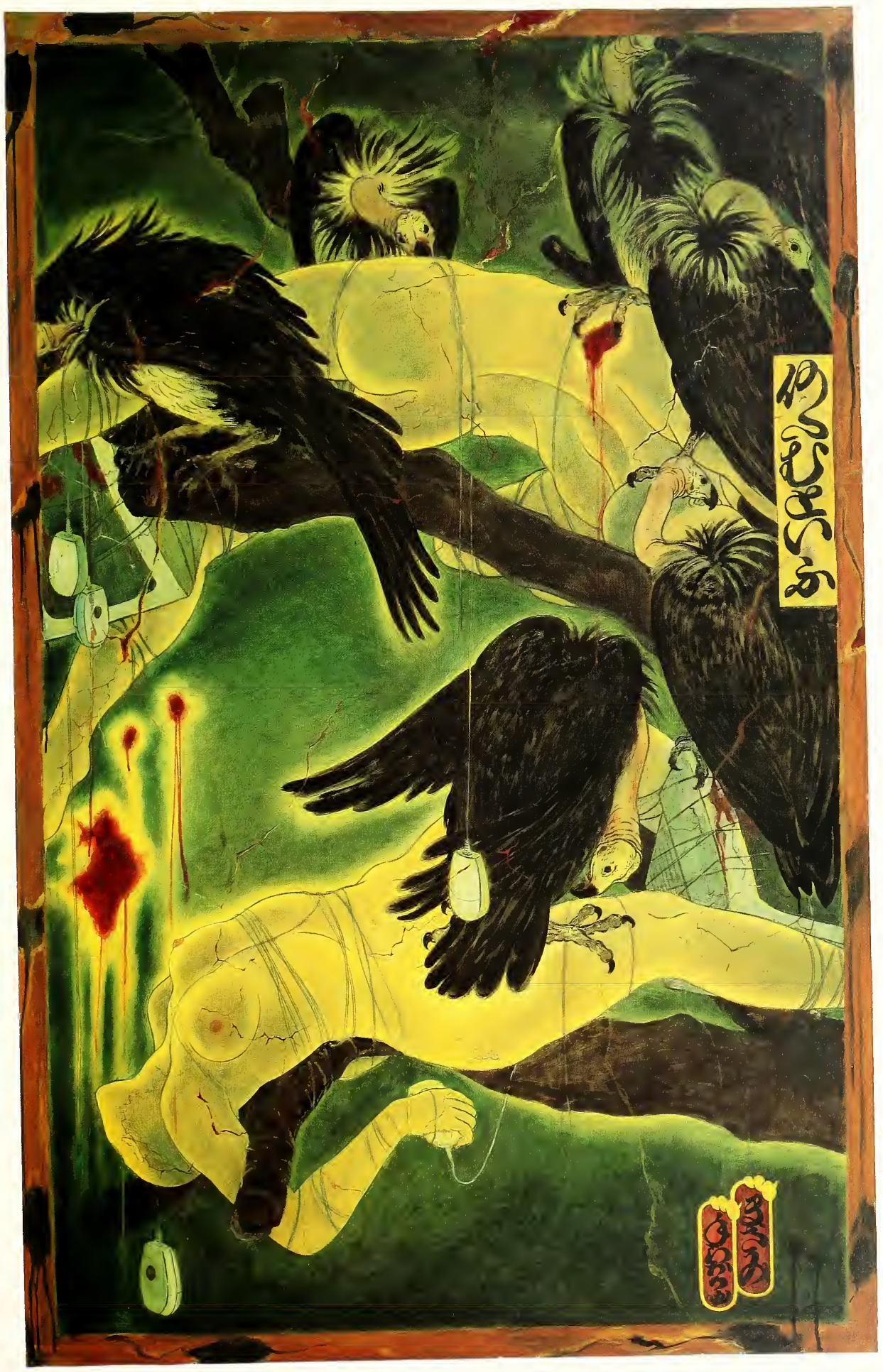


37 Eve with Three Blind Mice

1995

Watercolor on paper

$228.6 \times 106.7$

Private collection

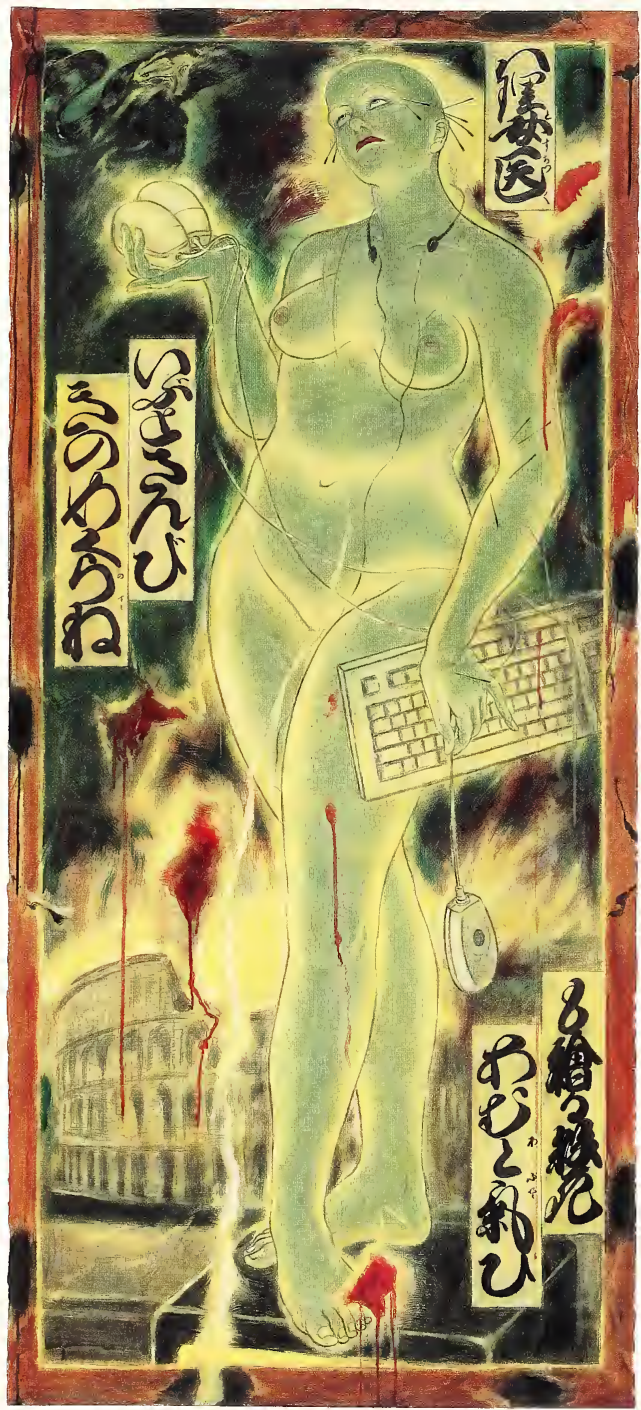




\section{Adam and Eve/Eve's Delivery}

1995

Watercolor on paper

$233.7 \times 106.7$

Courtesy of Pamela Auchincloss Gallery, New York

Eve is about to give birth. A moment ago, she was at her gym doing aeroboxing (a combination of aerobics and boxing — there's an exercise video on it!) and hoping she would have a natural birth. Suddenly she feels labor pains. Adam, who died of AIDS and is now a skeleton, swoops in on

Rollerblades to help Eve. On the way to the hospital,Adam the skeleton is shot by a random killer.

Lynda Hess and I were having dinner at a restaurant in Los Angeles with our friends Carl and Felice. We heard sounds ... pu, pu, pu. "That was a drive-by shooting," Carl informed us. We looked across the street and saw a man doubled over, trying to hold on to a lamppost.

Seventeen hours later, we were sitting outdoors facing the ocean, having tea. Soon we heard the same sound as the night before. Six continuous pu, pu, pu's. This time we knew it was bullets. We were ready to duck under the table, but no one else moved. The people at the next table briefly interrupted their lunch. "That's shooting," they said. "Well, it's not us."

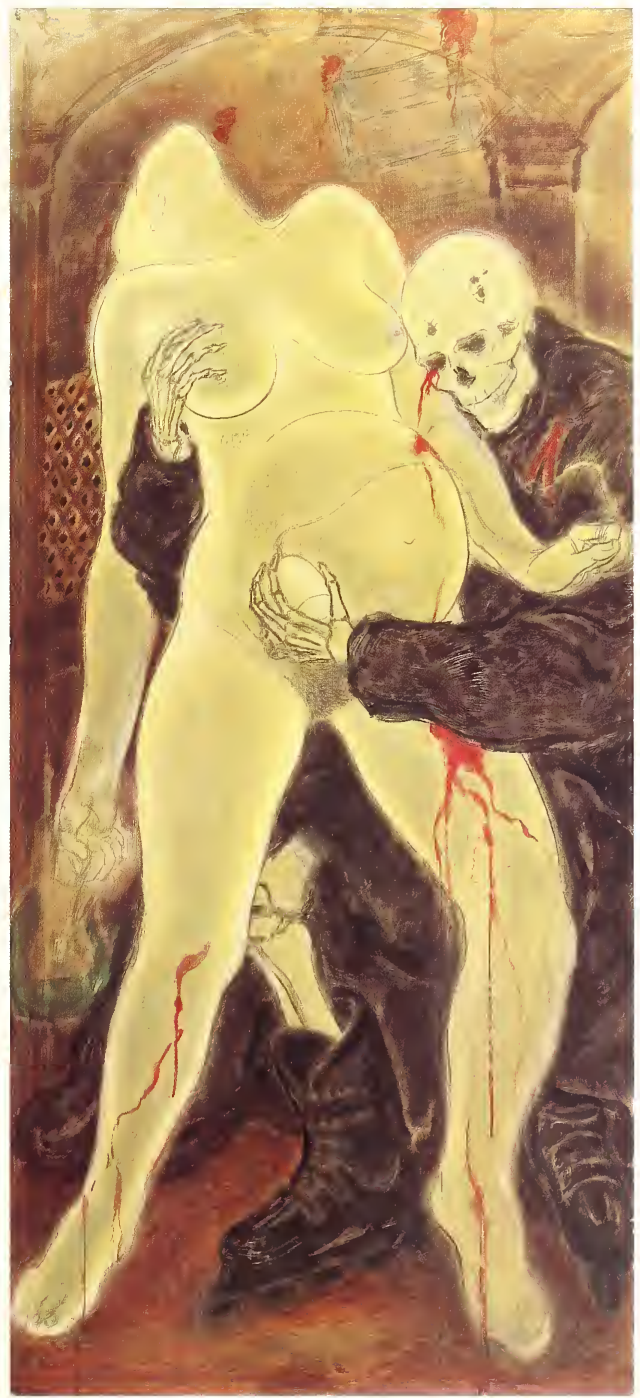




\section{Media Bacchanalia}

1995

Watercolor on paper, four panels

$238.8 \times 426.7$

Courtesy of Pamela Auchincloss Gallery, New York

Because the mass media need to have a competitive edge, sometimes they exaggerate stories and even report false statements, and some reporters are vicious as hyenas. I often wonder where they draw the line. Since the media are always hungry for information and gossip, icons of our society- politicians, actors, sports stars - have to be sacrificed. They are the martyrs of the information age. What about happiness, love, knowledge, and peace? We don't explore them enough to make us think about the positive things in life.

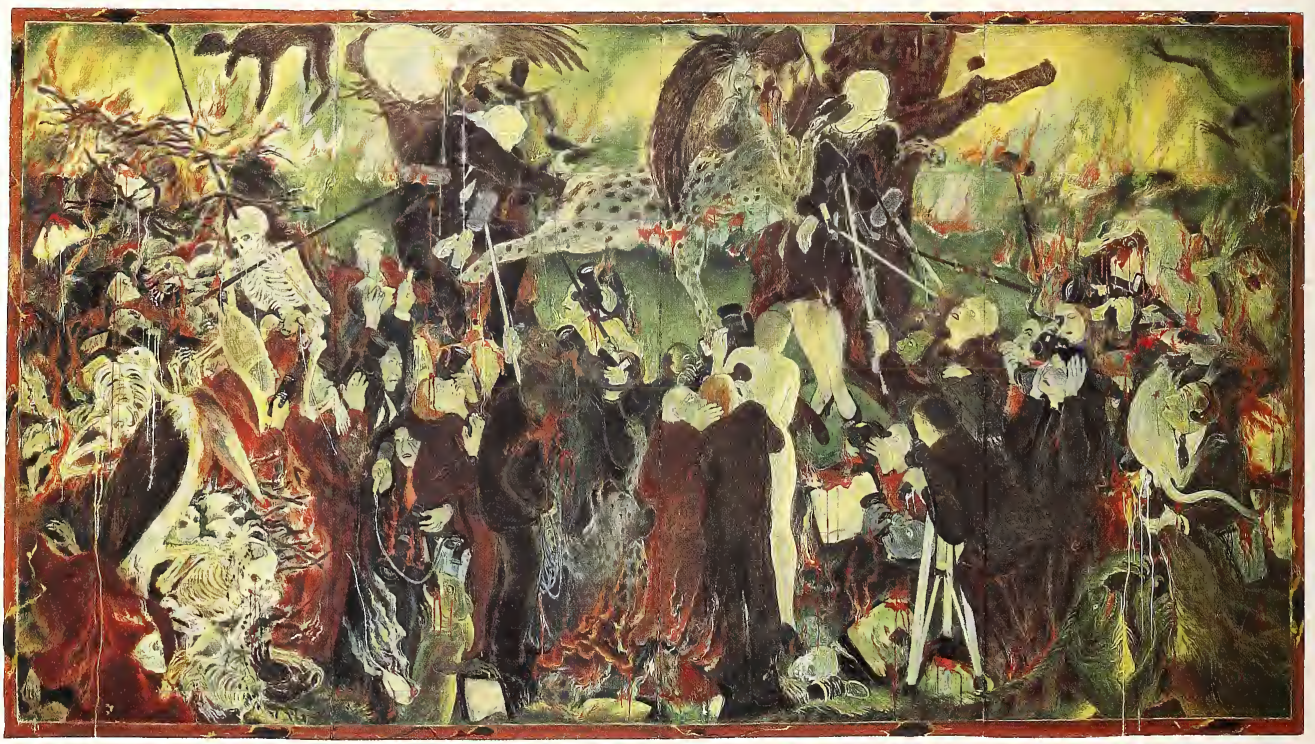




\title{
ANNOTATED BIBLIOGRAPHY
}

\section{Catfish in Love}

\begin{abstract}
Alter, Robert, and Frank Kermode, eds. The Literary Guide to the Bible. Cambridge, Mass.: Belknap Press, 1987. This important group of essays by various literary and biblical scholars stresses the methodology of literary analysis of biblical literature. It provides an excellent foundation for a grasp of the biblical themes that pervade Western literary and visual culture.J. P. Fokkelman's treatment of Genesis is especially helpful as it relates to Teraoka's most recent choice of themes.
\end{abstract}

Bonnefoy, Yves, comp. Mythologies: A Restructured Translation of "Dictionnaire des mythologies et des religions des sociétés traditionnelles et du monde antique" Prepared under the direction of Wendy Doniger. 2 vols. Chicago: University of Chicago Press, 1991. An adaptation of the French original, this is a collection of informative interpretive essays on world myth systems rather than a list of individual definitions. Some essays are organized by geographical categories and others by themes. Essays on Japan provide a basis for comprehending Teraoka's creative manipulation of mythic elements. Myth is not presented as monolithic dogma but as a dynamic and often ambivalent expression of various cultural truths.

Brown, Peter. The Body and Society: Men, Women, and Sexual Renunciation in Early Christianity. New York: Columbia University Press, 1988. Brown is one of the foremost authorities on late antique Mediterranean cultures. His important research and interpretations offer a context for early Christian attitudes about the body. These attitudes, sometimes anachronistically read as puritanical, were in their time radical. An appreciation of Teraoka's journey from Japanese to Western myth sources and the development of his "visual argument" can be enhanced by a reading of Brown's study. Brown's particularly incisive treatment of the writings of John Chrysostom and Augustine are best read in conduction with Elaine Pagels's somewhat more popular treatment (see below).

Dijkstra, Bram. Idols of Perversity, Fantasies of Feminine Evil in Fin-de-Siècle Culture. New York: Oxford University Press, 1986. Dealing with Western images of the feminine in fin-de-siècle culture, Dijkstra forcefully demonstrates the pervasive phenomena of misogyny and the demonization of women. Dijkstra's methodology is especially helpful in providing points of orientation from which to read Japanese images of related theme and content.

Doniger O'Flaherty,Wendy. Other Peoples'Myths: The Cave of Echoes. New York: Macmillan, 1988. This is an excellent introduction to the structure and functions of myth and mythmaking by a noted historian of religions. Doniger O'Flaherty offers approaches to contemporary issues of identity and meaning through an exploration of classic world myths and demonstrates how myth interpretation, properly understood, continues to be a viable route in the exploration of meaning. Mythmaking is at the heart of Teraoka's visual enterprise, and many aspects of this book can enrich a viewing of his art. "Other People as Animals: Rudra, Lord of Sacrificial Beasts" (ch. 4) may be helpful in understanding Teraoka's assumed identities.

Doniger O'Flaherty, Wendy. Dreams, Illusions and Other Realities. Chicago: University of Chicago Press, 1984. This is a sometimes dense but rich study of Hindu thought as it relates to the phenomenon of the dream. On a broader scale it is about myth and its epistemological efficacy, its ability to describe movements of transformation and to establish creative coexistence with contradiction. It may provide a productive framework for an appreciation of Teraoka's mythologizing process. 
Fox, Everett, trans. The Five Books of Moses: Genesis, Exodus, Leviticus, Numbers, and Deuteronomy. Vol. I of The Shocken Bible. New York: Shocken Books, 1995. Fox's superb translation and commentary reaffirm for the reader the radical nature of the Genesis message as it related to contemporaneous creation mythologies. This suggests that Teraoka's movement toward Genesis and related themes is not a random grazing at the banquet table of world myths but a choice of significant hermeneutic consequence.

Izzard, Sebastian. Kunisada's World. New York: Japan Society, 1993. This exhibition catalogue provides detailed information on more than one hundred prints and paintings and offers interpretive essays on the artist's biography and the literature and culture of nineteenth-century Japan. Kunisada's stylistic range and his pervasive influence in the ukiyo-e world are amply documented. This study is extremely helpful in understanding Teraoka's use and adaptation of images.

Jansen, Marius B., ed. The Nineteenth Century. Vol. 5 of The Cambridge History of Japan. Cambridge: Cambridge University Press, 1989. As a source of general historical information and interpretation, the Cambridge history project is unequaled. The format for the series is that of interpretive thematic essays rather than a narrative chronological presentation. Of particular relation to the subject matter treated by Teraoka are "The Tempo Crisis" by Harold Bolitho (ch. 2); "Late Tokugawa Culture and Thought" by H. D. Harootunian (ch. 3); "The Foreign Threat and the Opening of the Ports" by W. G. Beasley (ch. 4); and "Opposition Movements in Early Meiji, 1868-1885" by Stephen Vlastos (ch. 6).

Kitani, Makoto. Namazu-e shinko. Tsuchiura, Japan:Tsukuba Shorin, 1984. Until the appearance of Arata Shimao's study noted below, Kitani provided the most detailed information on the namazu (catfish) cult, its iconography, and its centrality in the vernacular of late-Edo-period culture. His work offers an intriguing selection of visual evidence taken mainly from mid-nineteenth-century prints.

May, Herbert G., and Bruce M. Metzger, eds. The New Oxford Annotated Bible, Revised Standard Version. New York: Oxford University Press, 1971. This is an excellent translation with a reliable appended critical apparatus. It offers an informative comparative reading with Fox's recent translation noted above.

Miles, Margaret R. Carnal Knowing. Female Nakedness and Religious Meaning in the Christian West New York: Random House, 1989. Miles explores cultural determinants for visual rendering of the human body as seen in Western religious iconography. The author is particularly interested in evidence that suggests oppression or subjugation of the female through imagery. "Adam and Eve: Before and After" (ch. 3) and "The Female Body as Figure" (ch. 4) offer enlightening discussions of iconography produced in the late Gothic and early Renaissance periods. The art of this era is influential on Teraoka, and Miles's interpretations shed light on his thematic interests. Her discussions of the portrayals of woman as seductress and witch and the possible imaging of women as influenced by the syphilis plague in Europe in the late fifteenth and early sixteenth centuries are stimulating,

Pagels, Elaine. Adam, Eve and the Serpent. New York: Random House, 1988. Pagels provides an excellent summary and interpretation of early Christian readings of the biblical creation narrative. She demonstrates the importance of the Genesis account to the development of Christian notions of free will, sin, and sexuality. Of considerable interest is her sympathetic reading of interpretive voices deemed heretical in the early Christian centuries. This study is useful in understanding the new symbolic system that Teraoka has recently chosen to explore.

Seznec, Jean. The Survival of the Pagan Gods: The Mythological Tradition and Its Place in Renaissance Humanism and Art. Princeton, N.J.: Princeton University Press, 1953. This important study points out the reasons for and range of intense Renaissance interest in pre-Christian mythology A resurgence of interest in the idealized human form influenced Christian iconography in the fifteenth and sixteenth centuries. Seznec offers weighty historical and literary insights into the images - insights that Teraoka has recently discovered by eye. 
Shimao, Arata. Josetsu hitsu Hyonenzu-Hyoton namazu no ikonoroji. Tokyo: Heibonsha, 1995. Shimao's highly creative assimilation and interpretation of salient cultural history from fifteenth-century Japan gives a fresh context to a famous Zen painting, Hyonenzu, by the monk artist Josetsu. This image of a man who seems to be attempting to subdue a catfish with a gourd is visually ambiguous and has been frequently interpreted as a kind of Zen riddle, or koon. Shimao offers extensive data on the cult of Chikubushima and the namazu (catfish), a phenomenon contemporary with the painting of the Hyonenzu, to explain that symbolic control or subjugation of the catfish as a creator element was a well-understood idiom in the fifteenth century. He brings the painting out of the aura of Zen mystery and suggests that its execution had much to do with affirming shogunal power. The study provides a wealth of detailed information on the namazu cult and its iconography throughout Japanese history.

Thompson, Sarah E., and H. D. Harootunian. Undercurrents in the Floating World: Censorship and Japanese Prints. New York: Asia Society Galleries, 1991. This work was published as a catalogue for an exhibition of the same title. It offers an excellent summary discussion of attempts at and subterfuge of ideological control in Edo-period society, particularly as seen in woodblock print images. The essays restore an important balance to the discussion of censorship of prints, noting that the sexually explicit works were understood as far less consequential than works that, by intimation of government ineptitude, satirized or subverted the established order. The pleasure worlds that the prints depicted were seen as baldly frivolous, and thus there were attempts to rein in such imagery in periods of enforced economic austerity. 


\section{Pulp Fiction and the Floating World}

Halbreich, Kathy. Culture and Commentary: An Eighties Perspective. Washington, D.C.: Hirshhorn Museum and Sculpture Garden, Smithsonian Institution, 1990. Commentaries by Maurice Culot, Vijak Mahdavi and Bernardo Nadal-Ginard, Michael M. Thomas, Sherry Turkle, and Simon Watney are included in this excellent study, which accompanied an exhibition. The book provides a rich cultural and political context for the understanding of fifteen artists, representing America, Japan, and Europe, whose work, in retrospect at decade's end, created the concept and style of eighties art. The Japanese artist included is Morimura Yasumasa.

Machida, Margo, Vishakha N. Desai, and John Kuo Wei Tchen. Asia/America: Identities in Contemporary Asian American Art. New York: Asia Society Galleries and the New Press, 1994. Essays by Margo Machida, Vishakha N. Desai, and John Kuo WeiTchen explore conceptual and practical questions of bicultural identity within the framework of the contemporary discourse on multiculturism. Twenty Asian-born artists working in America are included.

Munroe, Alexandra. Japanese Art after 1945: Scream Against the Sky. New York: Harry N. Abrams, 1994.This comprehensive study provides the first interpretive survey of postwar Japanese avant-garde art in the English language The book discusses the Japanese avant-garde within a broad context of the intellectual, cultural, political, and social history of Japanese modernism. Published in conjunction with a survey exhibition of postwar Japanese art, the book presents a history of art movements of the period, examines the cultural and critical environment of indigenous and emigrant artists, and includes an anthology of critics' and artists' writings, a glossary, and an extensive bibliography

Oikawa, Mariko, ed. Of the Human Condition: Hope and Despair at the End of the Century. Tokyo: Spiral/Wacoal Art Center, 1994. Contains essays by Susan Sontag, Fumio Nanjo, Hideo Fuse, and Dana Friis-Hansen and an interview with Alvin Toffler by Peter Schwartz. This catalogue accompanied an international exhibition of works by thirty-five artists dealing with questions of the human condition at the millennium.

Sussman, Elisabeth, et al. 1993 Biennial Exhibition. New York: Whitney Museum of American Art in association with Harry N. Abrams, Inc, 1993. This catalogue, which includes essays by cultural critic Homi K. Bhabha and artist Coco Fusco, marks the emergence of multiculturalism as mainstream art discourse. It explores the cultural politics of minority, immigrant, and ethnic groups in contemporary American society from a postmodernist point of view, defining their respective search for identity as a process of differentiation from the dominant white culture. AsianAmerican artists Bruce Yonemoto, Norman Yonemoto, Jamie Tanaka, Simon Leving, and Byron Kim are among those discussed.

Thompson, Sarah E., and H. D. Harootunian. Undercurrents in the Floating World: Censorship and Japanese Prints New York: Asia Society Galleries, 1991. An important historical investigation of this subject, it considers the ukiyo-e print as a subversive medium during the Edo period and suggests similarities to contemporary artists in their role as cultural critics. 
A la Maıson de M. Civeçawa, 41

actors: adaptation of pose of, 11 ; depictions of, in ukiyo-e, 17 Adam and Eve: Adam as AIDS victim, 99; Adam as victim of drive-by shooting, 53; Adam as war victim, 94; depicted in high-tech world, 98, 100; depicted in Renaissance, 14; Eve as Benzai-ten, 21; Eve in Bosnia, 94, 97; Eve contemplating the apple, 27-28; as Everyman and Everywoman, 31; Eve and condom use, 96; serpents and, 28, 31

aesthetics: mannerist, Teraoka as master of, 33; anti-aestheticism art environment of Los Angeles, 1960s, 39

AIDS (acquired immunodeficiency syndrome), 34; activist aesthetic, 45; as affecting transformational aspects of sex, 24; evolving treatment of by Teraoka, 12-13; paintings by Teraoka, $44-45,62,90,94,99$; symbols of, 28,45

Aloha, 36, 37

Ando, Hiroshige. See Hiroshige.

animals, real and mythological; bats, 45; cormorant, 19; dragon, 21; fox, 45, 76; frigate birds, 45; hyenas, 31; kappa, 27;

lizards, 31; octopus, 27, 77; serpents/snakes, 21, 28-30, 45, 94; vultures, 30, 31. See also catfish

art, as answer to question of human survival, 33, 48

Asano, Norigana, 25

Ashikaga, Yoshimochi, 22

Asia/America: Identities in Contemporary Asian American Art, 42 avant-garde, Japanese, 36-39, 109

Baldung-Grien, Hans, 13, 14

Basquiat, Jean-Michel, 41

battle themes in Edo period popular culture, 37

Benzai-ten, 21 ; Eve as, 29

Bhabha, Homi K., 43

Bible, 107; Genesis account, 29, 106, 107, 108; literary guide to, 106

blood: in "Adam and Eve" series, 30; motif in depiction of media, 31, 48, 53; in work of Shinohara Ushio, 37

body: early Christian attitudes about, 106, 108; in relation to self and other, 12; Teraoka on attitudes about, 85; Western themes, 13, 108

Bosch, Hieronymus, 13-14,46, 53, 98

Bosnia: Adam and Eve depicted in, 94; media coverage of, 46; refugees, 47

Buddhism: Benzai-ten deity, 21; cosmology, axis mundi, 21; distrust of flesh in, 14; final age (mappo), 25; jataka tales, 24; transience and impermanence notion in, 17-18; ukiyo-e and, 16, 17

California: depicted in work of Foulkes, 46; Los Angeles, 39 , 41, 42, 53; Santa Monica, 44; Venice Beach, I I-12, 23

catfish, namazu, 20-24, 27; linked to Genesis serpent, 29; paintings of, fifteenth- and seventeenth-century Japan, 22; studies of, 107, 108; as Teraoka's döppelganger, 23

Cat on a Flying Catfish, 23

censorship: Edo period, 17, 26, 108; government attitudes about Mapplethorpe photography, 72; Japanese and American attitudes about pornography, 85; parody of, in painting of Eve, 96

cherry blossoms, $33,38,53,64$

Chikubushima, Japan, 20, 21, 108
Christianity; censorship of images of, 35; early attitudes about the body, 106, 108; iconography, 46, 53, I08; incarnation and guilt in, 14

Chrysostom, John, 106

ColdWar, 36, 37

computers: monitors, keyboards, and mouses in paintings, 30-31, 47, 98; Teraoka's views on, 53, 98; used to manipulate images, in Japanese postmodern art, 48

conceptual art, 39, 40

condoms: in "Adam and Eve" series, 30; in AIDS awareness media, 5I; in AIDS paintings, 64, 77, 94; as contraceptives, 92; Eve as teacher of use of, 96; female, 99; symbolic meanings of, 24

consumer products and culture, 34; aerobics, 103; Ballantine ale, 39; Bazooka comics, 38; Betty Boop, 39; blond girls, 39; Brillo, 39; chewing gum, 37; Coca-Cola, 37; cowboys, 38; exercise videos, 103; Gold Coin condoms, 96; Golden Bat cigarettes, 39; golf bag, 42; Marlboro cigarettes, 37; Rollerblades, 30, 103; as subject of pop art, 36-39; toilet paper, 96

courtesans, 33, 38, 42, 64, 90

Cranach, Lucas, 48

creation stories: Chikubushima, 21; Genesis, 27-31, 108. See also Adam and Eve

Danziger, Peggy and Richard, 7

Doll Festival, 38

Edo period, 33; centrality of catfish in vernacular of, 107; discussion of attempts at and subterfuge of ideological control in, 108; erotic prints of, 39; social and political history of, 16-18, 25-26; themes of popular culture during, 37, 39; ukiyo-e print as subversive medium during, 109 environmental destruction, 12, 19,34,42, 44, 5 I

eroticism: censorship of, 35, 85; in "pop ukiyo-e," 36; shunga, 39; in work of Utagawa Kunisada, 15

female/male mythologies: deity and catfish, in ninth-century Japan, 21-22; in jataka tales, 24

Foulkes, Lyyn, 45, 46

Friis-Hansen, Dana, 45

geishas. See courtesans

genitalia: in "Adam and Eve" series, 30; attitudes about depictions of, Teraoka's view on, 85; manipulable seal concealing Eve's, 96

ghosts and ghost stories: in AIDS paintings, 62, 72, 90,99;

Teraoka on use of, 52-53; themes in Edo period popular culture, $37,44,45$

Golgotha, 30, 48

Gothic and Renaissance images, 13, 14, 47, 108

greed, as theme in paintings, 12,19

Haggerty, Gerard, 35

Hawaii: Hanauma Bay, 5I; as home of Teraoka, 4I, 50, as setting of paintings, 28

Hideyoshi, Toyotomi. See Toyotomi, Hideyoshi.

Hindu religion: dream and myth in, 107; Sarasvati, 21-22

Hiroshige Ando, 15, 39 
Hokusai Katsushika, 6, 15, 34, 39; Mt. Fuji painting by, 42; pearl diver painting by, 27, 77; Teraoka on, 50,77

Hung Liu. See Liu, Hung

Hyonenzu, 108

Iconography, European, 13, 108; Japanese religious, late fourteenth and early fifteenth centuries, 25 ; of saints and martyrs, 46,53

Japan: aesthetics of, 17-18; AIDS fear in, 90; Americanization of in postwar years, 36; avant-garde, 36-39, 109; catfish metaphor in political life, 22-23, 108; compassion (nasake) and obligation (gin) in, 50; earthquake, seventeenth-century, 22; forty-seven ronin incident, early eighteenth century, 25-26; history and interpretation of, 107; images of women, 106; laws against depiction of current events, 35; modern humanism in, 43; modernism, history of, 109; movement of court to Edo (now Tokyo), 22; movement of court to Kyoto, 20; mythologies, 20-21, 106; New Year's ceremonies, 25; opening to West, 22-23; political change in Heian period, 25; postmodern art of, 48; post-World-War-II social unrest and instability, 37; religious iconography in late fourteenth and early fifteenth centuries, 25; sacred places in, 20-21; social and political history, Edo period, 16-18, 25-26; state censorship in, 16-17,35, 108; Tokugawa shogunate, 35

"Japan style" in graphic arts, 36

Japonisme, 39,40

jazz, American, 37

Jensen, James, 40

Josetsu, 22, 108

Kabuki theater: depictions of, by Utagawa Kunisada, 15-16; forty-seven ronin as subject of, 26; images used by Teraoka, 28; mie gesture, 45; motifs of, 45 ; portrayals in ukiyo-e, 17; prints, 15, 26; themes of horror and cruelty in, 37; use in AIDS painting, 62; Yotsuya kaidan, 44

Kajima shrine, Japan, 22, 24

Katsushika Hokusai, See Hokusai Katsushika.

Kawanabe, Kyosai, 23

Kimmelman, Michael, 45

Kira, Yoshinaka, 25-26

Kitagawa, Utamaro. See Utamaro Kitagawa.

Kiyonaga Torii. See Torii, Kiyonaga.

Kunisada Utagawa, 6, 14-16, 34, 42; adaptations of, by Teraoka, I I: portrait of, 28; study of, 107; Teraoka on influence of, 50,86

Kurosawa, Akira, 18

Kyosai Kawanabe. See Kawanabe, Kyosai.

Kyoto, Japan, 20, 22, 25

Lake Biwa, Japan, 20, 22, 24, 29

landscape: consumed by fire, 31; portrayal of, in ukiyo-e, 17; sacred topography of, 20-21

Lichtenstein, Roy, 36, 37

Liu, Hung, 41

London, England:Teraoka on colors, sights of, 92, 94

Machida, Margo, 42

Mapplethorpe, Robert, 72

Masami Teraoka. See Teraoka, Masami

mass consumer culture. See consumer products and culture

media: effect on traditional notions of culture and religion,

48; images of, 31 ; pernicious effects of, 48 , 104; role in AIDS awareness, 51; violence and, 46, 48
Meiji era, 39

Messina, Antonello da, 13

Millet, Jean-François, 48

minimalist art, 40

minority artists, 40-43

Morimura, Yasumasa, 46, 48, 109

Mount Sumeru, 21

Mt. Fuji, Japan, 39, 42

multiculturalist movements: essays on artistic. 109; place of Teraoka within, 40-42

Murasaki Shikibu, 18

mythology: Japanese, 20-21, 106; of Teraoka, 29-30, 107 world systems, interpretation, 106-7

Nara, Japan, 20, 21: Saruzawa Pond in, 21, 24

nature and plants, 12; eggplants, 53, 93, 94; environmental

destruction themes, 12 19, 34, 42, 44, 51; images of union with, 27; pomegranate, 93; trees, 30, 100

Neo-Dada Organizers, 36

The New Renaissance, 45, 46

New York City: eclipse of "schools" of, in 1980s, 40

ninja: as safe sex rescuers, 93; as sexual observers, 28; as subjects of woodblock prints, 26; Teraoka as, 19, 27

Norigana Asano, See Asano, Norigana.

Oishi,Yoshio, 25

Oldenburg, Claes, 5 |

Osorio, Pepón, 41

parody: of sex-as-knowledge, 28-30; themes treated in, 34-35; use of ukiyo-e in work of Yokoo Tadanori, 39

Pearl Diver and Two Octopuses, 27,77

pop art: American and Japanese, 36-39; American tradition.

33; eclipse of, in 1980s, 40; Los Angeles style, 46

prints. See woodblock prints; ukiyo-e

prostitution: portrayal of, in ukiyo-e, 17. See also courtesans punk: depicted, 92; use of style to indicate Westernized Japanese, 83

rape: seizing of sexual power and, 28 ; woodblock print subject, as, 26-27

Rashomon, 18

Renaissance: Christian iconography, 46-47, 53, 108; images,

13, 14, 47, 108; world/flesh themes in, 13-14

Rising Sun, 39

rock ' $n$ ' roll culture, 39

ronin (masterless samurai), 25-26

sadism: themes in Edo period popular culture, 37

safe sex: eggplant images and, 53; in "London Tube" series, 93 in "Venice Beach" series, 24

samurai: depiction of traditional Japanese men as, 83; fortyseven ronin, 25-26; tattoos and, 89

Sengakuji temple, Japan, 25

sexuality: contradictions in, 14; knowledge of, as acquiring power, 28-30; night fishing metaphor, 19; rape imagery in late eighteenth-century prints, 26-27; state view of, seventeenth-century Japan, 16-17; transformational character of, as affected by AIDS, 24

Sherman, Cindy, 47

Shinohara, Ushio, 36, 37, 38, 39

shoguns: affirmation of authority, in painting, 22, 108; decline of authority, in Edo period, 16-17; Tokugawa, 35

shunga (erotic prints), 39

Smithsonian Institution Special Exhibition Fund, 7 
Social criticism: 1960s Japanese, 37-38; pop art themes, 36-39

socialism, in Japan, 37

Sussman, Elisabeth, 40

TadanoriYokoo. See Yokoo, Tadanori.

Taisho era, 39

The Tale of Genii, 15, 18

techniques: Teraoka on his, 52, 54; watercolor, of Teraoka, 34: woodblock, 29

technology, 12; personal use of, by Teraoka, 100; pop art criticism of, 36; role in AIDS plague, 51; Teraoka on, 98. See also computers

television: Teraoka on his viewing of, 100; violence, 46

Teraoka, Masami: on Adam and Eve in high-tech world, 98 ,

100; on aesthetics, 39,55; age at achievement of signature style, 33; AIDS effect on course of art of, 44-45; allegory in work of, 4l; art student in Los Angeles, 34, 50; art-critical writings of, 40; artist-in-residence, 58; attitudes about America, 50; birth and education of, 56; as Buddhist priest, 19; caricature in work of, 48; as catfish, 20, 23-27; on childhood and education, 52; on color, 52; on consumerism and resulting pollution, 51 ; critical views of, in 1970s, 40; detached position of, 43; disappearance of ukiyo-e style in work of, 48; exhibitions of, 1973-96,40 42, 56-58; family business of, 39; as fisherman/warrior, 19; graphic sources of mature work of, 33; group exhibitions, 1974-96, 57-58; on Hieronymus Bosch, 53, 98; on his influences, $34,50-51$; on his vision of humanity's dilemmas and destiny, 43, 55; on his life and art, 50-55; humor in work of, 34, 52; on humor in presenting dread subjects, 52; identities assumed in work, 18-19, 107; interest in and uses of ukiyo-e, 33-35; on Japanese tourists in Hawaii, 50 , 80,86 ; lectures by, 58 ; loosens attachments to Nihon-teki, "the Japonesque," 48; love and sexuality, attitudes about, 85; multiculturalist aspects of work of, 40-42; mythologizing by, 29-30, 107; as ninja, 19,27; on personal use of technology, 100; photograph of, 60; as pilgrim, 11, 18, 20, 23, 27; on pop art, 50, 51; pop adaptations of, 39; prominence of, 40; public collections of works of, 58-59; on random violence, 103; as searcher/observer/change effector, I8-20, 23, 31; self-portraits of, II, |2,41-42; sex-asknowledge themes and parodies in work of, 28-30; solo shows, 1973-96, 56-57; style inspired by northern European and Renaissance art, 47; subject matter and themes of, 34-35; on technique, 52, 54; tours Europe, 46: U.S. residency and citizenship of, 40; use of conventions of nineteenth-century woodblock print, 13,48; use of

European iconography by, 13, 108; use of ukiyo-e style by $39,50,107$; use of ukiyo-e style in AIDS paintings, 28, 52: use of ukiyo-e style as Japanese ready-made, 39; youth in remote harbor town, 33. See also Works by Masami Teraoka

theater. See Kabuki theater

Tokugawa, leyasu, 35

Torii, Kiyonaga, 15

Toyokuni Utagawa. See Utagawa Toyokuni.

Toyotomi, Hideyoshi, 35

Tsukioka, Yoshitoshi, 37

28 Murders, 38 ukiyo (floating world): history of, 16-18; traditional subjects of 33

ukiyo-e: and AIDS paintings, 28, 52; Edo period, 17, 35, 37, 39 , 107, 108; historical study of, 109; pictures of Utagawa Kunisada as, 16, 107;" pop," 36, 38; portrayal of theater and brothel in, 17; print size, 54; as source of Teraoka's work, 33-35, 39, 50, 107

Ushio Shinohara. See Shinohara, Ushio.

U.S.-Japan Security Treaty, 37

Utagawa, Kunisada.See Kunisada Utagawa.

Utagawa, Toyokuni, 15

Utamaro Kitagawa, 15, 35

violence: drive-by shootings, 53; in Edo-period theater and art, 16; images associated with media, 48, 53; media saturation with, 46; random shootings, 47, I03; reactions against, by 1960 s Japanese avant-garde, 37-38

voyeurism: ninja depicted as peering or leering, 27, 28; parody of erotic tradition, 33; woodblock print subjects, as, 26 Warhol, Andy, 39

watercolor: See techniques

Wesselmann, Tom, 51

women: AIDS-stricken, 44, 62, 64; Caucasian, 33; courtesans, $33,38,42,64,90$; depicted by Utagawa Kunisada, 15, 42; female abalone divers, 26-27; in work of Cindy Sherman, 48; misogyny and demonization of, 106; namazu's relation to, 27; as objects of perverse fantasy and abuse, 48 ;

Oiwa, 44; rape as subject of prints, 26-27; as seductresses and witches, 108; subjugation of through imagery, 108; voyeurism as subject of prints, 26. See also Adam and Eve woodblock prints, Japanese: centrality of catfish in late Edo period, 107; conventions of, I2; female abalone divers as subjects of, 26-27; ghost story scenes in, 37; horror and cruelty themes in, 37; nineteenth- and twentieth-century lapanese, 15: ninja subjects of, 26: process and techniques of, 29; publisher's role in production of, 29; seal marks in, $12,29,35$; use of text in, 12,35 . See also ukiyo-e

works by Masami Teraoka: "Adam and Eve" series, 30, 38, 47, 53, 69, 97-101, 103; "AIDS" series, 28, 33, 44, 45, 51-53, 62-76, 102; "Hawaii Snorkel" series, 10, II, 20, 23, 28 , 86-88; 'McDonald's Hamburgers Invading Japan" series, 33, 34, 37; "London Tube" series, 19, 27, 29, 93; Media Bacchanalia, 48, 53, 104-5; New Views of Mt Fuij/La Brea Tar Pits Amusement Park, 4I-42, 43; New Views of Mt. Fuji/La Brea Tar Pits and Zen Garden, 19; "New Waves" series, 20, 52,77-85; Tale of a Thousand Condoms, frontispiece, 89-92; "Tree of Life" series, 47, 53, 94-96; Santa Monica Pier, 19, 20; 31 Flavors Invading Japan/Rocky Road, 19.37; Venice Nude Beach/Bicycle and Woman, II, 12; Venice Nude Beach/Self-Portrait, 1 1, 12, 18, 31

Yasumasa Morimura. See Morimura, Yasumasa.

Yokoo, Tadanori, 36, 38, 39, 41

Yoshimochi Ashikaga. See Ashikaga, Yoshimochi.

Yoshinaka Kira. See Kira, Yoshinaka.

Yoshio Oishi. See Oishi, Yoshio.

Yoshitoshi Tsukioka. See Tsukioka, Yoshitoshi.

Zen riddles (koan), 22, 108 




\section{ABOUT THE AUTHORS}

James T. Ulak, associate curator of Japanese art at the Arthur M. Sackler Gallery and Freer Gallery of Art, Smithsonian Institution, has an abiding interest in Japanese narrative painting.

Alexandra Munroe is author of Japanese Art after 1945: Scream Against the Sky (1994) and curator of the accompanying exhibition, which toured the United States in 1994-95.

Masami Teraoka has exhibited internationally for many years and published comments on his work. Lynda Hess is an independent artist and collaborates with Teraoka on numerous projects. 
SMTTHSONIAN LIBRARIES

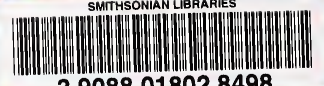
39088018028498 